$\sum_{n}^{n}$
${ }_{N}$

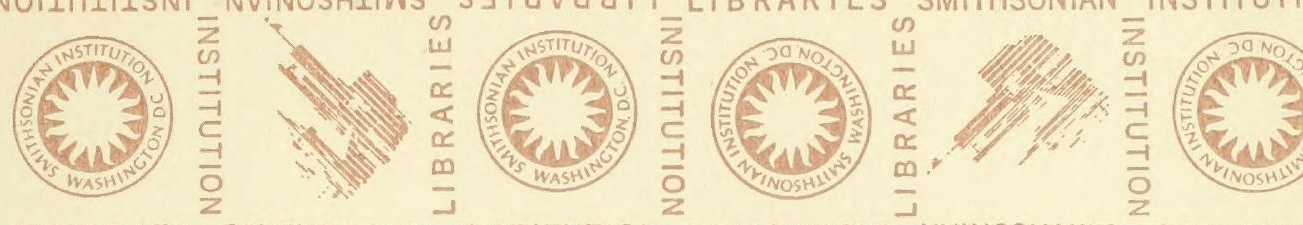

LIBRARIES SMITHSONIAN INSTITUTION NOILNIIISNI NVINOSHLIWS SZIVYY

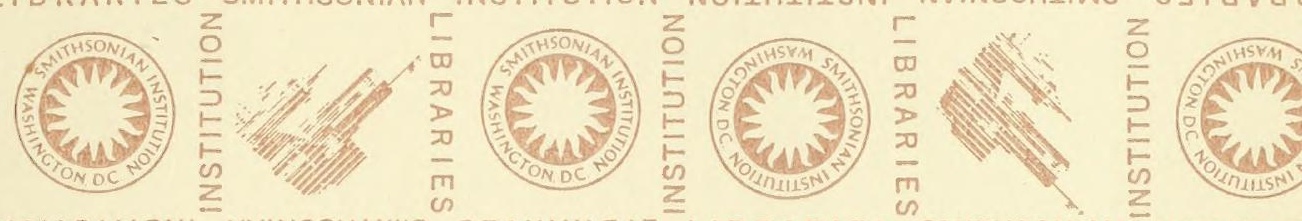

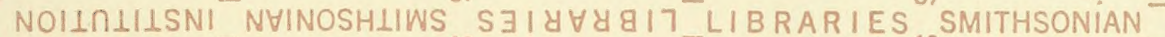
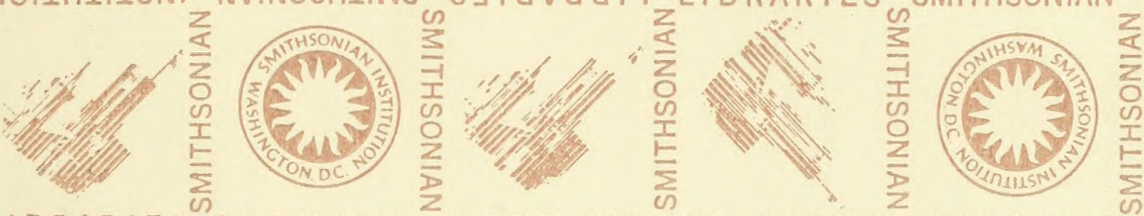

INSTITUT

LIBRARIES SMITHSONIAN
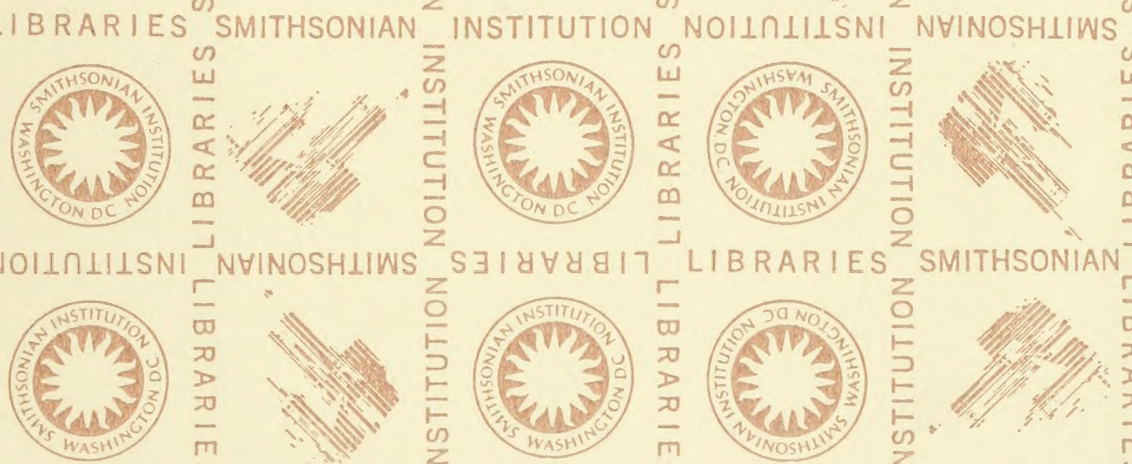

$S \exists I \forall \forall \forall$

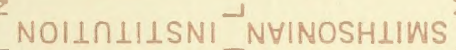
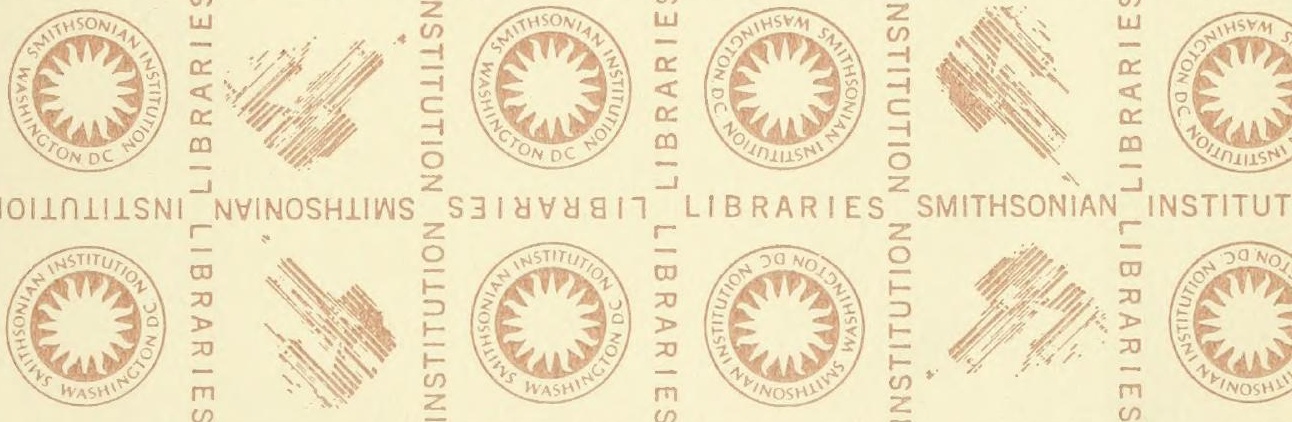

LIBRARIES SMITHSONIAN

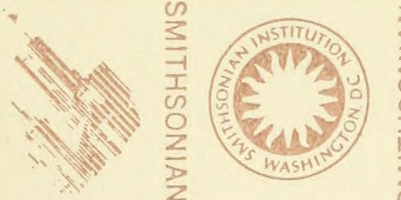

$$
\begin{aligned}
& Z^{2} \\
& \bar{a} \\
& 0 \\
& 0 \\
& \text { I } \\
& \text { I } \\
& \hline \sum
\end{aligned}
$$

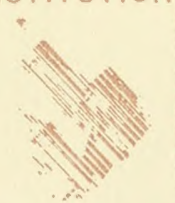

NOIINIILSNI
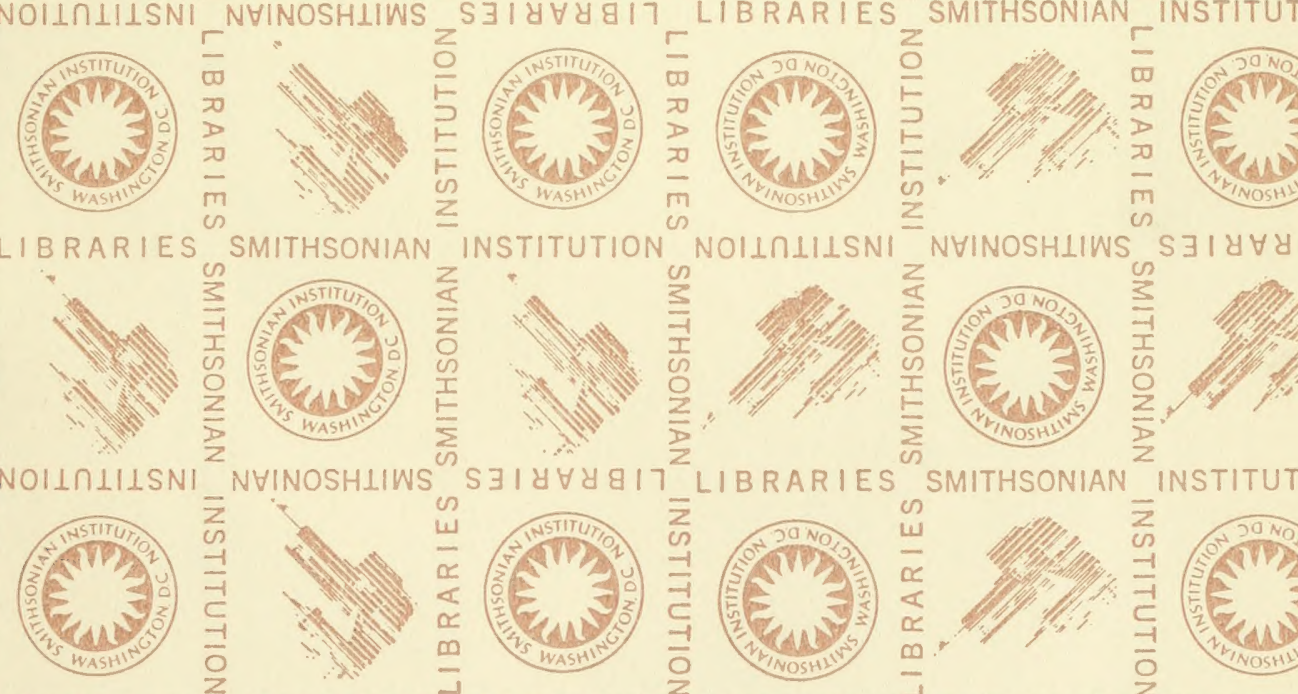

LIBRARIES SMITHSONIAN
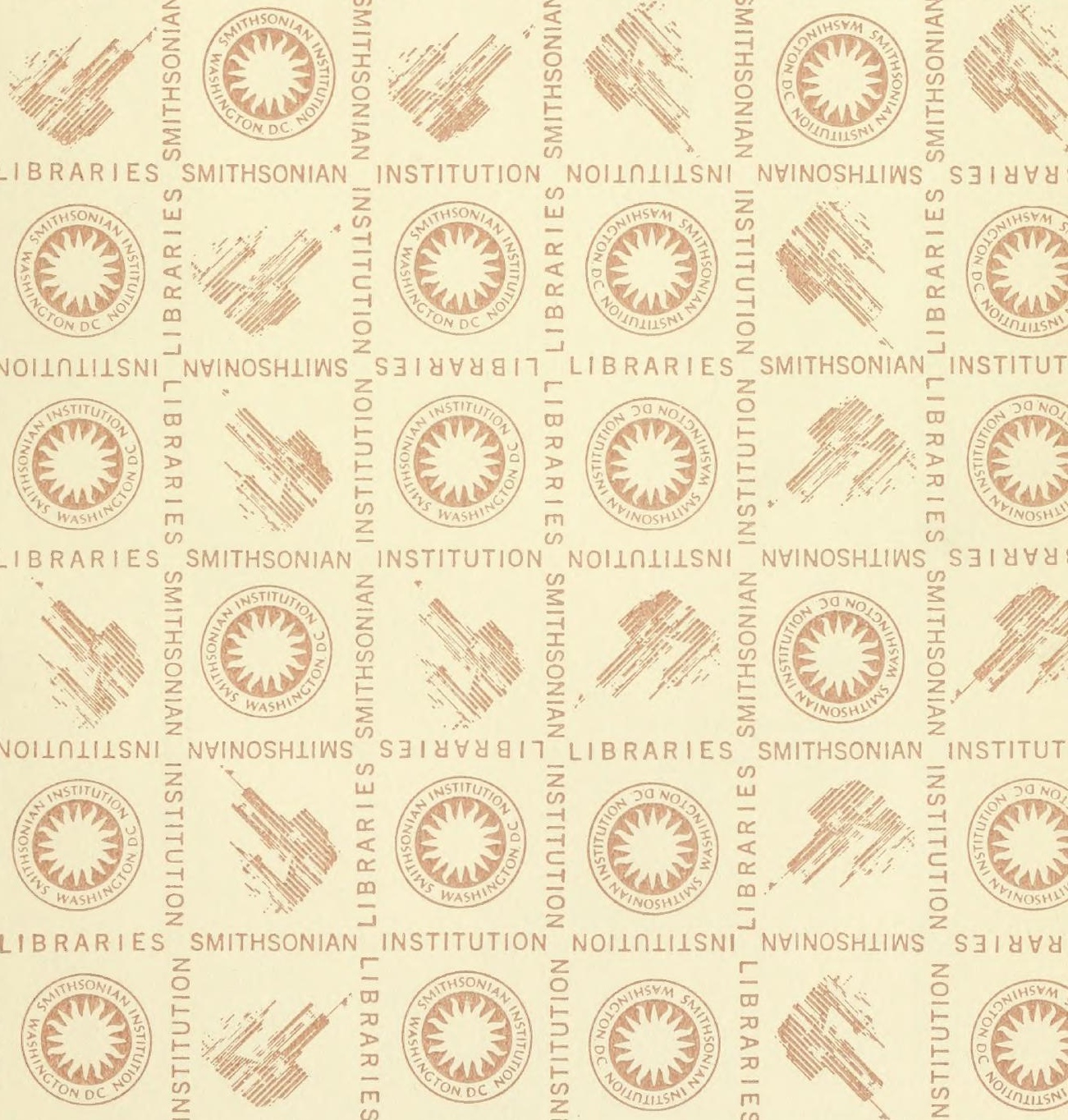

NOILIIILSNI NYINOSHLIWS
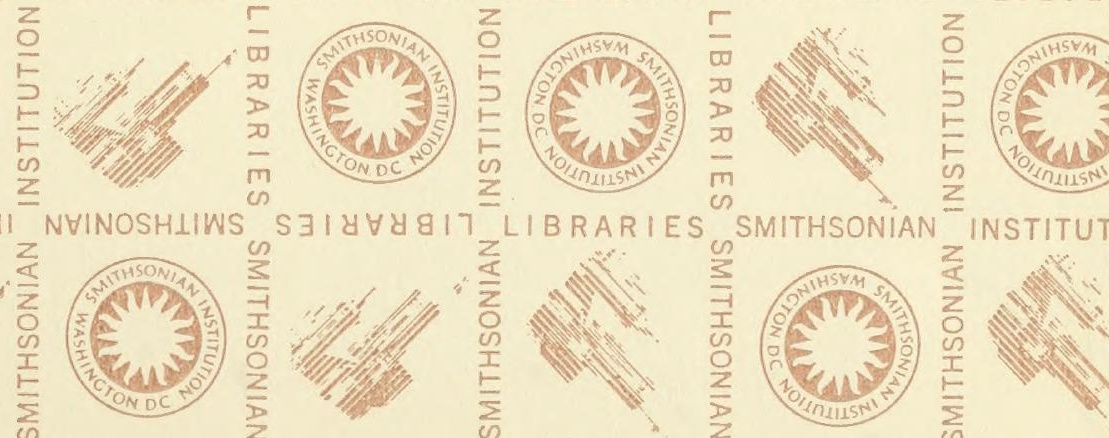
INSTITUT 




\section{VoL. III, $1914 . \quad$ PART 1.}

\section{PROCEED I N G S}

OF THE

\section{PORTLAND SOCIETY}

OF

\section{NATURAL HISTORY.}

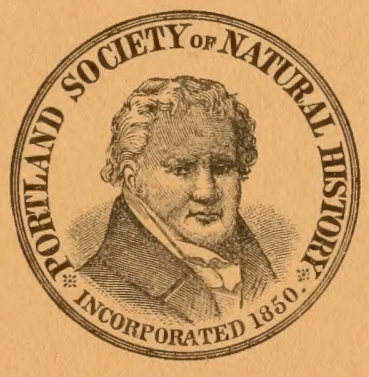

ORGANIZED 1843.

CONTENTS.

I. WILLIAM CONVERSE KENDALL: The Fishes of Maine.

Portland, Maine, U. S. A.

PRINTED FOR THE SOCIETY.

1914. 



\title{
An Annotated Catalogue of the Fishes of Maine.
}

\author{
By William Converse Kendall,
}

Scientific Assistant U. S. Bureau of Fisheries.

As scientific assistant of the federal government institution, now known as the Bureau of Fisheries, Department of Commerce, the writer has spent a considerable portion of the last twenty years in studying the habits and geographical distribution of the marine and fresh-water fishes of Maine. The work has several times taken him by water the entire length of the coast, and he has visited many of the bays and fishing centers. On the fresh waters, all of the larger and most important lakes and rivers, as well as many of the minor waters, have been explored. The information thus acquired affords the basis for the present catalogue.

The coast of the State is very irregular and deeply indented. Hundreds of islands dot its bays, coastal waters and estuaries, and outlying shoals or "banks" form important fishing grounds for various commercial fishes. Maine has an area of about 32,000 square miles, of which probably about $65 \%$ is woodland and there is a large area that may be said to be under water. There are four large river basins and numerous smaller drainages, and about 2,000 lakes from 100 acres to 120 square miles in area.

The waters of Maine are poor in species compared with the southern States. In the present catalogue there are listed 149 species, some of which are of uncertain occurrence.

The fish fauna of the salt water is mainly boreal. There are some periodical migratory species that have their relation- 
ship in the south, and a few occasional stragglers from southward, and accidental visitors. From the appended lists it may be seen that there are 98 species that may be considered almost or quite strictly marine. Of these but 17 are at present of any commercial value. Of the 149 species, also, only 35 can be called strictly fresh-water forms, and some of these are so on account of physical restrictions. About fourteen or fifteen of these are food fishes of more or less importance and some of them highly esteemed game fishes. There are sixteen species of anadromous, katadromous, and those commonly occurring in either fresh or salt water.

Maine was one of the first States to undertake fish culture. In 1867 , the first State Fish Commission was appointed, since which time various species have been propagated and distributed. Since 1872, the U.S. Fish Commission has co-operated in the work, and vast numbers of young fish have been planted in the waters of the State. Many depleted lakes and streams have been restocked with trout. Landlocked salmon have been introduced into many waters not before containing them, where they have become acclimated and increased in numbers. A number of species foreign to the State have also been introduced, but without pronounced success, so far as authentically known, except in the case of the black bass, which in suitable waters has proved a valuable food and game fish, and in others has become somewhat of a nuisance. By the aid of both well-meaning and mischievous persons, the pickerel has been spread over a wide area to which it was not indigenous. Smelts seem to have been a success in almost every instance of their introduction, in some lakes having wonderfully increased in numbers and size.

Although the transplanting of excellent food and game fishes has been highly successful, the wisdom of indiscriminate introduction of exotic forms into waters whose native species is all that can be asked for in size, food and game 
qualities is questionable. To the writer it seems that if the native fish have become scarce, if possible, it alone should be propagated for such waters and the native stock thus restored. If non-indigenous species are introduced, especially if the native form is already on the decrease and the foreign fish particularly hardy and vigorous, the alien will doubtless thrive at the expense of the native, if the waters are suited to the introduced form. Even if the native stock is not waning, the introduction of another struggler for existence is liable to upset the balance of nature that previously existed. There is no dearth of lakes in Maine, which are as well adapted to lake salmon as the few that are famed for their superb trout. If possible, these few trout lakes should be maintained and the others replenished with salmon and nonnative trout.

Aside from pike perch, black bass, carp and goldfish, all of the introduced forms belong to the salmon family which are represented by a number of species from Europe and the west.

The following lists respectively include the foreign and American species not native to Maine that have been introduced. Only one, the small-mouth black bass (Micropterus dolomien) has become sufficiently established to be admitted as a Maine fish. In the following lists the asterisk (*) indicates those which have been reported from one or more localities since their introduction. 


\section{FOREIGN.}

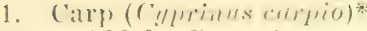

$\therefore \quad$ Goldfish (Carassius auratus)*

$\therefore$ Vendace (Lencichthys albula)

4. Seoteh sea trout (Salmo trut$t a)^{*}$

5. Brown trout (Salmo fario)*

i. Loch leven trout (Salmo lerensis)

7. Swiss lake trout (Salmo lemumus)

\section{AMERICAN.}

1. Whitefish (Coregonus clupeaformis)*

2. Chinook salmon (Oncorhynchus tschawytscha)*

$\therefore$ Silver salmon (Oncorlhynchus kisutch)

t. Humpback salmon (Oncorhynchus yorbuscha)

). Steelhead trout (Salmo yairdneri)

ii. Rainbow trout (Salmo irideus)*

7. Grayling (Thymallus montanus)

- Sinall-mouth black bass ( $\mathrm{K} i$ cropterus dolomieu)*

1) Large-mouth black bass $(\mathrm{Mi}$ cropterus salmoides)

10. Pilie perch (Stizostedion ritreum) 


\section{HISTORICAL.}

The following catalogue and bibliography of the fishes of Maine aim to include at least one record of each species known to occur in the waters of the State. By the term record as here used is meant a published notice that a fish has been collected in Maine, bearing the technical name of the species, definite locality, and date of publication. No record is included unless well authenticated, and no species* is included without authentic record, barring a few necessary exceptions, $i_{\text {. e.: }}$ 1. When the present writer has personal knowledge that the species occurs in Maine, though there is no complete published record, in which case such data as are available are accepted. 2. When an authentically labeled fish occurs in a collection and has been examined by the present writer. 3. When the writer has received assurance from a reliable person that he has collected or observed the fish.

The bibliography and other records and references which follow the catalogue, are arranged chronologically. The year of publication or reference is given first, followed by the name of the authority and title of record and name of publications in which it occurs, or explanation of reference, usually with list of species recorded, with identification of all names by the writer.

In the catalogue the technical name is given first, followed in small capitals by such common names as are in local use. References to localities are then given, followed by the name of the author or collector, with date, in parentheses. Example,

*Some of the older lists, as Holmes', contain one or two doubtful, though possible, occurrences. Such are the toadfish (Opsanus tau) and weakfish (Cynoscion vegalis). These are retained for the sake of keeping this list complete. 
Eastport (Bean, 1880), means that the fish was collected in Eastport and that the record of it is made by Bean and will be found under 1880 in the chronological list of records; the letter " $a$ " after date indicates a second paper by the author in the same year, and " $b$ " indicates a third. Casco Bay (Kendall coll., 1896), indicates that the species was collected by Kendall in Casco Bay in 1896, no published record of which has been made. "Coll," means in every instance collection of, or observed by. Portland (U. S. N. M., 1873), shows that the species was collected at Portland in 1873 and the record is found in the catalogues of the Department of Fishes of the U.S. National Museum, and explanation of this fact can be found in the list of records and references under the year 1873 in the chronological list of records. Me. F. C. Report means Maine Fish Commission Report, and U. S. F. C. refers to the United States Fish Commission.*

Nany more or less definite references to the same locality have been omitted for the sake of conciseness. Others occurring in sportmen's journals covering a period of many years, often lacking some element of definiteness, have been omitted because value received would hardly be commensurate with the time and labor entailed in compiling them.

Because a species of fish has been recorded from Maine waters is not absolute proof that it occurs there, and that it has never been recorded is not positive evidence that it does not occur; in fact, there are doubtless other fishes than those herein recorded occurring in the waters of the Maine coast, especially in deep water, which are rarely caught, and then only by accident, by trawl, or deep-water fishermen. Occasionally some of these forms die and are washed up on the shore or are found floating at the surface. Such was the case with Macroums bairdi at Eastport. It would be expected that such fishes as are known to occur on the Nova

*Further explanations will be found at the end of the catalogue. 
Scotia shore, especially west of Halifax, and in. Massachusetts Bay or Cape Cod Bay, should now and then appear on the coast of Maine.

The first publication, known to the writer, containing a list of technical names* of Maine fishes is "The History of the State of Maine from its First Discovery, A. D. 1602 to the Separation, A. D. 1820, inclusive", by William D. Williamson, in two volumes, published by Glazier, Masters \& Co., at Hallowell, in 1832. Section V of Vol. I comprises an account of the "Native Animals, Beasts, Birds, Fishes, Vermes, Reptiles and Insects". The chapter on fishes begins on page 150 and extends to and includes page 164 .

The author says: "In our salt and fresh waters are found about sixty species of fish, and generally they are abundant in numbers. Some are warm blooded, some amphibious, some without bones, and some without scales-differently classed by different ichthyologists."

In the list of fishes are included several mammals, as the whale, blackfish, porpoise and seal.

In Section II of the same volume, describing the "Face of the Country, Seacoast, Islands, Rivers, Mountains and Soils" some fishes are alluded to by their common names. These references and those of the list, the technical names of which are given in footnotes, contain 59 nominal forms, representing 56 good species.

With the exception of the above mentioned list and a few references to or descriptions of one or more species from Maine the earliest work on Maine Fishes is that of Dr. Ezekiel Holmes in 1862, which also is the only considerable catalogue of Maine fishes. Dr. Holmes' work consists of a history of the fisheries, a classification of the fishes, in which

\footnotetext{
*Josselyn's (1672 and 1674) accounts of fishes, though in the form of lists, are archaic productions, with non-technical names. The species are often questionable, and frequently entirely unidentifiable.
}

Though Sullivan (1795) presents several scattered notes on fishes, no list is griven. 
he claims to present the systems of Willoughby and Ray, Dale, Artedi, Linnæus, Cuvier, Lacépède, Agassiz, Girard and Gill, with a history and explanation of each, a glossary of the terms used in ichthyology and the characteristics of the orders. Under "Girard's system" is presented a partial list of the fishes of Maine. In part 2 under "Gill's system" is given another partial list, in which the generic and specific names are sometimes changed and a few names added.

Following this is a descriptive catalogue of a part of the fishes of Maine, in which some of those enumerated in the precerling lists are not given and an additional species described. The first list comprises the names of 67 species; the second, 76 species, and the last list 34 species. Of these. after a reduction to a common denominator, 73 valid species remain, 68 of which are undoubtedly found in Maine waters. The others very probably may be found occasionally, straying from the southward.

In the parallel columns following the reference to Dr. Holmes in the bibliography are given the names of the fishes enumerated in the three lists of Dr. Holmes and the identification of the species. The names of those not known to occur in Maine are indicated with an asterisk. The fresh-water cusk or burbot was erroneously called Ophidium marginatum, which does not occur in Maine and is a salt-water fish. I am unable to ascertain to what fish he refers as Fario tsuppitch, since this is evidently a synonym of Oncorhynchus kisutch or silver salmon of the Pacific Coast, unless it be $S$. sebago. 


\section{CATALOGUE.*}

MYXINIDA. The Hagfishes.

1. Myxine glutinosa Linnous. Hagfish; "Sline EEL"; "BORER".

Range.-North Atlantic on both coasts; south, in deep water, to latitude of Delaware at least.

MAINE.-Along the whole coast on muddy offshore grounds ; off Casco Bay (Kendall coll., 1888, and Kendall, 1908); Eastport (Kendall coll., 1893); White Head Mud (Norton coll.).

\section{PETROMYZONIDA. The LAMPREYS.}

2. Petromyzon marinus Linncus. LAMPREY; "Lajiper Eel”; Sucker; Great Sea Lajrprey.

Range.-Atlantic coasts of Europe and North America; south to Florida.

Maine.-Piscataquis (Williamson, 1832); Maine (Holmes, 1862, and Kendall, 1908); Eastport (U. S. N. M., 1872); Presumpseot River (Me. F. C. Report, 1875); Bucksport (U. S. N. M., 1878); Kennebec (Me. F. C. Report, 1880); Casco Bay (Lee, 1885); brook in Brunswick (Bowdoin College coll., 1900 [?]); Small Point, Casco Bay (Kendall coll., 1896); Stillwater River (in Maine State University, Merrill coll., 1898); Penobscot River (Kendall coll., 1902); East Branch Penobscot (Atkins coll., 1903); Penobscot River and Bay (Evermann, 1903).

*Explanation of abbreviations used not elsewhere explained will be found at the end of the catalogue. 
CHLAMYdoselachide. 'The Frilled Sharts.

8. Chl a my dos e la hus anguineus Guman. Fritled Shark: "Sea Serpent".

Range.-Deep waters of the open sea.

MaIne.-New Harbor [?] (Hanna, 1883); Pemaquid [?] (Goode \& Bean, 1896).

CarCHARINID A. The Requiem Sharks.

4. Carcharinus obscmus (Le Sueur). Dusir SHARK.

Range.-Middle Atlantic, frequent on coast of North America.

Marne.-Near Cod Ledge, summer of 1864 (Willard, 1895).

VULPeCULID E. The Thresher Sharks.

5. Vulpecula marina Valmont. Thresher SHART; Thresher ; "Swingletail"; "Sivingletail Shark"; "SivivelTAIL": "SWIVELTAIL ShaRK".

Range.-All warm seas, especially Mediterranean and Atlantic; frequently taken on Pacific coast.

MAINE.-In our bays, one was caught eastward of Matinicus, in 1811, which was supposed to weigh more than 500 pounds (Williamson, 1832); Eastport (Kendall coll., 1893); off Monhegan (Kendall coll., 1893 and 18956); Maine (Kendall, 1908).

CARCHARIDA. ThE SAND Sharks.

6. Carcharias taurus Rafinesque. SAND SHARK; "Shovelnose SharK"; "Blue DoG"; Little MaCKerel SHARK.

Range.-Maine to Cape Hatteras.

Marne.-Maine (Gill, 1873, and Kendall, 1908); coast 
of Maine (Goode, 1884); Casco Bay (Lee, 1885); Casco Bay at Small Point (Kendall coll., 1896).

ISURID A. The Mackerel Sharks.

7. Isurus punctatus (Storer). "MACKEREL SHARK." Range.-Maine to West Indies.

Maine.-Caseo Bay (U. S. N. M., 1873, and Kendall, 1908); off Seguin (P. S. N. H. coll., 1908).

8. Isurus nasus (Bonnaterre). "MaCKerel SharT"; "Blue Shark".

Range.-North Atlantic and North Pacific.

Maine.-Off Monhegan (Storer, 1867, and Kendall coll., 1895b); Portland (Bicknell, 1868); Casco Bay (Bowdoin College coll., 1900 [?] ); off Cape Elizabeth (Willard, 1895, and Norton coll., 1905 and 1906); Maine (Kendall, 1908).

9. C a r ch a rod o n carcharias Linncus. GREAT White ShariK. Man-eater; Man-eater Shark.

Range.-All temperate and tropical seas.

MaIne.-Eastport (Goode, 1884, and Kendall, 1908).

CETORHINIDA. The Basking Sharks.

10. Cetorhinus maximus (Gunner). "BAsting Shakik"; "Bone Shark".

Range.-Aretic Seas, southward to Portugal, Virginia and California.

Maine,-Maine (Holmes, 1862, and Kendall, 1908); off Cape Elizabeth (Storer, 1867, and Goode \& Bean, 1896); Eastport (Verrill, 1871 and 1872, and Goode, 1884).

$$
\text { SQUALIDA. The Dogrishes. }
$$

11. Squalus acanthias Limneus. "DoGFish."

Range.-Gulf of St. Lawrence, south to Cuba. 
MAINE.-Maine "Salt water" (Williamson, 1832, Goode, 1884, Mle. S. and S. F. Report, 1907, and Kendall, 1908): Eastport (U. S. N. M., 1872, and Bean, 1880); Caseo Bay (Lee, 1885); Small Point, Casco Bay (Kendall coll., 1896); Passamaquoddy Bay (Moore, 1897); Matinicus, Isle au Haut, Stockton Springs, Searsport, Gott's Island, Mt. Desert Rock, Sandy Point, Verona (Evermann, 1904); Saco Bay.

SCymarhinide. 'The Nurse Sharks.

1․ Somniosus microcephahus Schneider. "Nurs: Shark"; Sleeper Shark.

Range.-Aretic Seas south to Cape Cod, Oregon and France.

Marne.-Eighty miles east of Portland (IVood, 1846, and Storer, 1848); Maine (Holmes, 1862, and Kendall, 1908); eighty miles east of Portland (Storer, 1867); Eastport (U. S. N. M., 1875); Portland (Goode \& Bean, 1896).

\section{RAIIDA. The Skates.}

13. R a i a e i na cea Mitchill. "Skate"; Little Strate; Comion Skate.

Range.-Virginia northward.

Maine.-Eastport (U. S. N. M., 1872); Casco Bay (Lee, 1885); Casco Bay at Small Point (Kendall coll., 1896); Wolf's Neek, Freeport (Pettengill coll., 1900); New Meadows River (Bowdoin College coll., 1900 [1890]); Maine (Kiendall, 1908).

14. Raia diaphanes Mitchill. Big Skate; SkAte; Spotted SKate.

Range.-New York and northward.

Matxe.-Eastport (U. S. N. M., 1872); Casco Bay (U. S. N. M., 1873); Portland (Goode \& Bean, 1879); Small Point (Kendall coll., 1896); Maine (Kendall, 1908). 


\section{Raia radiata Donovan. SpIN S SkAte.}

Range.-North Atlantic, America and Europe.

Maine.-Casco Bay [?] (P. S. N. H.); Casco Bay (Lee, 1885); Maine (Kendall, 1908).

16. Raia stabuliforis Garman. "BARNdOOR SKATE."

Range.—South to Florida.

MaIne.-Maine (Williamson, 1832) ; Eastport [?] (U.S. N. M., 1872); Casco Bay at Small Point (Kendall coll., 1896); Maine (Kendall, 1908).

NARCACiontid A. The Electric Rays.

17. Narcacion nobilianus (Bonaparte). TORPEDo; "Cramp Fish"; "Numib Fish".

Range.-Maine to Cuba.

Maine.—Off Seguin Island, Wood Island, Bald Head and Casco Bay (Kendall coll., 1896, and Smith \& Kendall, 1898); Maine (Kendall, $1903 a$ and 1908).

ACIPENSERIDA. The Sturgeons.

18. Acipenser sturio Linnceus. "STURGEON."

Range.--Europe and North America; St. Lawrence River' to Gulf of Mexico.

MAINE.-Kittery, and Kennebec River (Sullivan, 1795); "Salt water into rivers" (Williamson, 1832); Kennebec and Portsmouth (Eaton, 1851); Maine (Holmes, 1862); Kennebec River (Storer, 1863); Kennebec and Androscoggin Rivers (Atkins, 1887); Caseo Bay at Small Point (Kendall coll., 1896); Cathance River (Kendall coll., 1901); Casco Bay (Lee, 1885); Topsham and Small Point (Goold, 1886); Penobscot River (Kendall coll., 1902); Penobscot River and Bay (Evermann, 1904); Maine (Kendall, 1908). 
SILURIDA. The CATTIShes.

19. Ameimus nebulosus (Le Sueur). "Horn PouT"; BUllhead ; "Johrny"; Cateish ; Bullpodt.

Range. 'Throughout the Great Lakes and south to T'exas and Florida.

MAINE.-Almost all our fresh water's (Williamson, 1832); Maine (Perley, 1852, Storer, 1855, Holmes, 1862, and Jordan \& Evermann, 1896); Auburn (U.S. N. M., 1883); 'Thompson Pond (Bowdoin College coll., 1900 [1883?]); brook in Brunswick (Bowdoin College coll., 1900 [1893?]); Sabattus Pond (Kendall coll., 1880); Boyden, Big and Leweys Lakes, West Branch St. Croix, 'Tomah Stream and Magurrowock Stream (Kendall, 1894); Taylor Pond and Pushaw Pond (Merrill coll., 1899); Sebago and Little Sebago Lakes and Presumpscot River (Kendall coll., 1898, 1899 and 1900a); Cobbosseecontee Lake (Kendall coll., 1899a, and Smith, 1901); East Branch of Penobscot River and Bill Fish Brook (Kendall \& Gould coll., 1900); Umsaskis, Round and Glasier Lakes (Kendall \& Gould coll., 1901); Little Sebago Lake (Kendall coll., 1902); Green Lake and Cross Lake Thoroughfare (Kendall coll., 1903) : common (Atkins coll., 1903); Moose and Indian Ponds and Sebasticook River (Bowman coll., 1904); Oquossoc Lake (Kendall coll., 1904) ; Umbagog Lake (Kendall coll., 1905); Kennebec at Bath (W. H. Rich coll.); Maine (Kendall, 1904 and 1908).

\section{Catostomide. The Suckers.}

20. Catostomus catostomus (Forster). "ReD Sucker"; LongNosed Sucker; Northern Sucker; "RED-SIDED SUCKER".

Range. Great Lakes, Labrador to Alaska, and has been recently found in the mountains of $\mathrm{W}$ est Virginia.

Maine. -Cupsuptic Lake (B. S. N. H., Putnam coll. 
[1866?]); Rinngeley Lake (Hitchcock, 1862); Skiff Lake of the Eastern Schoodic Chain of Lakes and upper waters of the Androscoggin River (Adams, 1873); Craig's Pond (Merrill coll., 1898 and 1899); Glasier Lake and Cross Lake Thoroughfare (Kendall \& Gould coll., 1901, and Kendall, 1903a); Square Lake (Kendall coll., 1903); Craig's Pond (Atkins coll., 1903); Umbagog Lake (Kendall \& Goldsborough coll., 1905); Maine (Kendall, 1908).

21. C a to s tom us commersonii (Lacépède). "Sucker"; Black Sucker; White Sucker; Common SUCKER; "BARVEL".

Range.-Quebec and the Great Lakes to Montana, Colorado, and southward to Missouri and Georgia and west to Kansas.

MAINe.-Piscataquis River (Peck, 1804); fresh water (Williamson, 1832); Maine (Holmes, 1862); Moosehead Lake (B. S. N. H., Davidson coll.); Grand Lake Stream (U. S. N. M., 1877); Crooked River (Atkins, 1878); Bear River (Bowdoin College coll., 1900 [1885 ?] ); Freeport (Kendall \& Smith, 1894, and Kendall coll., 1898, 1899, 1900, 1901b, 1902, 1903 and 1904); Boyden, Pennamaquan and Meddybemps Lakes, Dennys River, Grand Lake Stream, Big and Leweys Lakes, St. Croix and tributaries (Kendall, 1894); Chickawaka Lake and outlet (Kendall coll., 1895a); Grand Lakes (Rathbun \& Wakeham, 1897); Sebago and Little Sebago Lakes and Presumpscot River (Kendall coll., 1898, 1899 and 1900a); Thomas Pond (Kendall coll., 1899); Lake Auburn and Androscoggin River (Merrill coll., 1899); Cobbosseecontee Lake (Smith, 1901); Cobbosseecontee and Maranacook Lakes (Kendall coll., 1899a); Sebago Lake (B.S. N. H., Putnam coll. [1865?], and Smith, 1900); Matagamon and Matagamonsis Lakes, East Branch of Penobscot River and Rangeley Lakes (Kendall \& Gould coll., 1900); Bill Fish 
Brook, Telos and Chamberlain Lakes, Smith Brook, Eagle, Churchill and Round Lakes, St. Johms River between Cross Rip and Rankin Rapids, Glasier Lake and Cross Lake 'Thoroughfare (Kendall \& Gould coll., 1901); South Fork of East Branch of Royals River (Kendall coll., 19016 and 1904); Wissataquoik Deadwater, Lunkasoos Lake, Great Spring Brook, Sand Bank Brook and Wissataquoik River (Kendall \& Gould coll., 1902); Presumpscot River (B. S. N. H., Putnam coll. [1866?], and Kendall coll., 1902); Maine (Kendall, 1903a); brook tributary of Thomas Pond, Presumpscot River, outlet Chaffin Pond, Simpson Brook, East Branch of Royals River, Great Brook, Mann Brook, Winkempaugh Brook, First Debsconeag Lake, Cross Lake and Thoroughfare, Square Lake and Thoroughfare, and Rangeley Stream (Kendall coll., 1903); everywhere (Atkins coll., 1903); Eagle Lakes and brook tributary to Casco Bay (Evermann, 1904); Moose and Indian Ponds, and Sebasticook River (Bowman coll., 1904); Oquossoc Lake (Kendall coll., 1904); Cambridge River (B. S. N. H., Putnam coll., 1866); Umbagog Lake (Kendall coll., 1905); Maine (Iiendall, 1908).

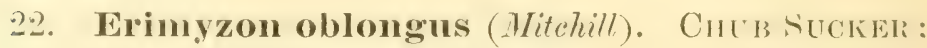
"Pot Belly"; "NuB-Nose"; "ROACH".

Range.-Great Lakes region, the Dakotas south to Indian Territory and Virginia, represented from Virginia to Texas by typical Erimyzon sucette.

MAnE.-Maine (Holmes, 1862); Sebago and Little Sebago Lakes, and old canal at head of Presumpscot River (Kendall coll., 1898); Pettengill Pond (Kendall coll., 1899); tributary of Presumpscot River (Kendall coll., 1899); Thomas Pond (Kendall coll., 1899); mouth of Songo River (Kendall coll., 1900a); Harrison (Atkins coll., 1903); Maine (Kendall, 1908). 
CYPRINIDA. The Carps and Minnows.

23. Chrosomus erythrogaster Rufinesipue. "GoLnSide"; Red-Bellied Minnow.

Range.-Recorded from no place between northern New York and Maine; it occurs south to Alabama and west to Nebraska and Dakota in one or more of its sub-species.

Maine.-Auburn (U. S. N. M., 1883, and Merrill coll., 1899); Freeport (Kendall \& Smith, 1894, and Kendall coll., 1898, 1899 and 1900); Cobbosseecontee Lake (Kendall coll., 1899a); Bill Fish Brook and Cross Lake Thoroughfare (Kendall \& Gould coll., 1901, and Kendall, 1903a); Cross Lake Thoroughfare (Kendall coll., 1903); Bangor (Lee coll., 1903); Maine (Kendall, 1908).

24. Pimephales anuli Kendall. Blunt-rose Minnow; Ring's Minnow.

Range.-Thus far known only from Maine.

MAINE.-Cross Lake Thoroughfare (Kendall \& Gould coll., 1901, Kendall, 1903a, and Kendall coll., 1903); Lunkasoos Lake (Kendall \& Gould coll., 1902, and Kendall, 1903a); Salmon Lake (Kendall coll., 1903); Maine (Kendall, 1908).

25. Semotilus bullaris Rafinesque. "CHUB"; "DACE"; "Silver Chub".

Range.-Although one of the commonest species in New England, hảs not a very wide range. Found mostly east of the Alleghanies as far south as the James River.

MaIne.-Maine (Williamson, 1832, Putnam \& Pickering, 1865, and Pickering, 1865); Rangeley Lakes (Hitcheock, 1862); Grand Lake Stream (Adams, 1873, and U. S. N. M., 1877); Auburn (U. S. N. M., 1883); Thompson Pond (Bowdoin College coll., 1900 [1883 ?]) ; Umbagog Lake and 
Rapid River (Kendall coll., 1883); Bear River (Bowdoin College coll., 1900 [1885?]); Freeport (Kendall \& Smith, 1894, Kíndall \& Grould coll., 1900, and Kendall coll., 1898, 1899, 1901b, 1902 and 1903): Boyden, Dennys and Pennamaquan Rivers, Grand Lake Stream and West Branch St. Croix River (Kendall, 1894); Sebago and Little Sebago Lakes, Songo and Presumpscot Rivers (Kiendall coll., 1898, 1899 and 1900a); Pettengill and Panther Ponds, and Cobbosseecontee Lake (Kendall coll., 1899 $\alpha$ ); Cobbosseecontee Lake (Smitl, 1901); Androscoggin River and Lake Auburn (Merrill coll., 1899); Rangeley Lake, Auburn Lake, Ship Pond Stream, Bill Fish Brook, and Matagamon and Matagamonsis Lakes (Kendall \& Gould coll., 1900); Presumpscot River (Kendall coll., 1901a, 1902 and 1903); Ambajejus Falls, Debsconeag Lakes, Pokwokamus Deadwater, East Branch of Penobseot River, Matagamon, Matagamonsis, Webster, Telos, Chamberlain, Eagle, Churchill, Umsaskis and Beau Lakes, and Cross Lake Thoroughfare (Kendall \& Gould coll., 1901); Moosehead Lake, Wissataquoik Deadwater, East Branch and Bowlin Pond (Kendall \& Gould coll., 1902); Debsconeag Lake (Smith, 1903); Presumpscot River, outlet of Chaffin Pond, East Branch and South Fork of East Branch of Royals River, Mann Brook, Green Lake, Floods Pond, First Debsconeag Lake, Cross Lake, Oquossoc Lake and Rangeley Stream (Kendall coll., 1903); East Branch and South Fork of East Branch of Royals River, Oquossoc Lake and Floods Pond (Kendall coll., 1904); everywhere in Maine (Atkins coll., 1903); Moose and Indian Ponds and Sebasticook River (Bowman coll., 1904); Umbagog Lake (Kendall coll., 1905); Maine (Kendall, 1904 and 1908).

26. Semotilus atromaculatus (Nitchill). Brook Chuв; "Mumi-chub". 
Range.-Presents a gap in its range, being thus recorded by Jordan and Evermann, Maine, western Massachusetts to southern Missouri, Wyoming and Canada. It has also been collected in Colorado. A sub-species is found in the waters of some of the southern states.

MAINE.-Maine (Lindsley, 1844, Atkins coll., 1903 and Kendall, 1904 and 1908): Auburn (U. S. N. M., 1883); Thompson Pond (Bowdoin College coll., 1900 [1883?]); Fireeport (Kéndall \& Suith, 1894, Jordan \& Evermann, 1896, and Kendall coll., 1898, 1899, 1900, 1901, 1902 and 1903); Cobbosseecontee Lake (Kendall coll., 1899a, and Smith, 1901); Bill Fish Brook and Matagamonsis Lake (Kendall \& Gould coll., 1900, and Smith, 1902); First and Second Hurd Ponds, Southard's Pond, Bill Fish Brook, Telos, Chamberlain and Eagle Lakes, Smith Brook, Umsaskis and Round Lakes, and Cross Lake Thoroughfare (Kendall \& Gould coll., 1901); Sebois River and Bowlin Pond (Kendall \& Gould coll., 1902, and Kendall, 1903a); South Fork of East Branch and East Branch of Royals River, Simpson Brook, Mann Brook, inlet and outlet of Floods Pond, Second Hurd Pond and Cross Lake Thoroughfare (Kendall coll., 1903); South Fork of East Branch of Royals River, Floods Pond and Oquossoc Lake (Kendall coll., 1904).

27. Lenciscus carletoni Kendall. ChUB-MnNow: Carleton's Chub-Minnow.

Range.- Known only from Maine.

MAINE.-Bill Fish Brook (Kendall \& Gould coll., 1900, and Smith, 1902); Bill Fish Brook, Webster Lake, Smith Brook, Telos Lake, Southard's Pond, and Cross Lake Thoroughfare (Kendall \& Gould coll., 1901); Cross Lake Thoroughfare (Kendall, 1903a, and Kendall coll., 1903): Bangor (Lee coll., 1903); Maine (Kendall, 1904 and 1908). 
28. Phoxinus neogaeus (('ope). Broxze Mixnow.

Range.-Exhibits a wide hiatus in its range, previous to its discovery in Maine and New Brunswick, being known only from a few specimens from Livingston County, Michigan; Baraboo River, Wisconsin; White River, Arkansas; and the Black Hills of South Dakota.

MAINE.-Bill Fish Brook and Matagamonsis Lake (Kendall \& Gould coll., 1900, and Smith, 1902); Bill Fish Brook, Matagamonsis and Webster Lakes, Southard's Pond, Smith Brook and Cross Lake Thoroughfare (Kendall \& Gould coll., 1901): Lunkasoos Lake (Kendall \& Gould coll., 1902, and Kendall, 1902b); Cross Lake Thoroughfare (Kendall coll., 1903); Cambridge River (Kendall coll., 1905); Maine (Kendall, 1904 and 1908).

29. A bra m is crysoleucas (Mitchill). SHINER; "Bog Shiner"; "Herring"; Golden Shiner; "FreshWATER HERRING"; ROACH.

Range.-Nova Scotia to Dakota, Florida and 'Texas.

MA1NE.-Maine (Williamson,1832, Holmes, 1862, and Kendall, 1904 and 1908); Auburn (U. S. N. M., 1883); Pennamaquan and Leweys Lakes, West Branch St. Croix and St. Croix Rivers, and Magurrowock Stream (Kendall, 1894); Chickawaka Lake and outlet (Kendall coll., 1895a); Auburn and Cobbosseecontee Lakes (Merrill coll., 1899); Sebago and Little Sebago Lakes (Ḱendall coll., 1898 and 1899); Thomas, Chaffin and Pettengill Ponds and Cobbosseecontee Lake (Kendall coll., 1899a); Cobbosseecontee Lake (Smith, 1901); Bill Fish Brook and Matagamonsis Lake (Kendall \& Gould coll., 1900); Bill Fish Brook and Matagamonsis Lake (Kendall \& Gould coll., 1900); Bill Fish Brook and Cross Lake Thoroughfare (Kendall \& Gould coll., 1901); Presumpscot River and Little Sebago Lake (Kendall coll., 1902); Sebois River (Kendall \& Gould coll., 1902); Hurd 
Pond (Smith; 1903); Cross Lake Thoroughfare (Keudall coll., 1903); Umbagog Lake (Kendall coll., 1905).

30. Notropis bifrenatus (Cope). Bride Mixrow.

Range.-In Maine known only from the Sebago Lake or Presumpscot River basin; is otherwise recorded from Massachusetts to Maryland.

Maine.-Sebago and Little Sebago Lakes (Kendall coll., 1898); Chaffin Pond and tributary of Rattlesnake Pond (Kendall coll., 1899); mouth of Songo River (Kendall coll., 1900); Sebago and Little Sebago Lakes (Kendall, 1903a); Maine (Kendall, 1908).

31. Notropis kendalli Evermann \& Cockerell. KENDALl's Minnow.

\section{Range.-}

Marne.-Maine (Kendall, 1908); Hay Brook and Bill Fish Brook (Kendall \& Gould coll., 1900, Smith, 1902, and Kendall, 1903a); Smith Brook and Cross Lake Thoroughfare (Kendall \& Gould coll., 1901); Cross Lake Thoroughfare (Kendall coll., 1903, and Evermann \& Cockerell, 1909).

32. Notropis cornutus (Mitchill). "ReDFIn"; "ShINer"; "Buck Fish".

Range.-Common over the entire region east of the Rocky Mountains excepting the South Atlantic States and Texas.

MaINE.-Maine (Holmes, 1862, Putnam \& Pickering, 1865, and Kendall, 1904 and 1908); Freeport (Kendall \& Smith, 1894, and Kendall coll., 1898, 1899 and 1900); Boyden and Pennamaquan Lakes, I)ennys River, Grand Lake Stream, West Branch St. Croix and St. Croix Rivers (Kendall, 1894); Chickawaka Lake (Kendall coll., 1895a); outlet of Auburn Lake and Harlow Brook (Merrill coll., 1899); Sebago and Little Sebago Lakes and Presumpscot River (Kendall coll., 
1898, 1899 and 1900a); Pettengill Pond (Kendall coll., 1899); Cobbosseecontee Lake and tributaries, and Maranacook Lake (Kendall coll., 1899a); Rangeley and Auburn Lakes, Last Branch of Penobscot River and Matagamonsis Lake (Kendall \& Gould coll., 1900); First and Second Hurd Ponds, Debsconeag Lakes, Webster and 'Telos Lakes, Smith Brook, Eagle, Umsaskis, Round, Glasier and Beau Lakes, and Cross Lake 'Thoroughfare (Kendall \& Gould coll., 1901) ; Little Sebago Lake (Kendall coll., 1902); East Branch and Bowlin Pond (Kendall \& Gould coll., 1902); outlet Chaffin Pond, Mann Brook, Second Hurd Pond, Cross Lake Thoroughfare, Goddard Brook and Square Lake (Kendall coll., 1903); common (Atkins coll., 1903); South Fork of East Branch of Royals River, Floods Pond and Oquossoc Lake (Kendall coll., 1904); Umbagog Lake (Kendall. coll., 1905, and Adams, 1873).

33. $\mathbf{R} \mathbf{h} \mathbf{i} \mathbf{n}$ i $\mathbf{c h} \mathbf{t h} \mathbf{y}$ s atronasus (Mitchill). "ROCK Shrner"; Blacknose DACE; "Pot Belly"; Broor MinNow.

Range.-New Blunswick to Minnesota, Virginia and northern Alabama.

MAINE.-Maine (Arlams, 1873, andKendall, 1904 and 1908): Parmacheenee Lake (B. S. N. H., Snow \& Whittier coll.); Sebago Lake (B. S. N. H., Putnam coll. [1865?]); Auburn (U. S. N. M., 1883) ; brook in Brunswick (Bowdoin College (:oll., 1900 [1893?]) ; Dennys River and Grand Lake Stream (Kendall, 1894); Freeport (Kendall \& Smith, 1894, and Kendall coll., 1898, 1899, 1900, 1902, 1903 and 1904); (hickawaka Lake (Kendall coll., 1895a) ; Bear River (Bowdoin College coll., 1900 [1885?]); tributary of Presumpscot River, tributary of Panther Pond and.tributary of Cobbosseecontee Lake (Kendall coll., 1899 $\alpha$ ); Lake Auburn outlet, and Stillwater and Penobscot Rivers (Merrill coll., 
1899); East Branch of Penobscot and Matagamonsis Lake (Kendall \& Gould coll., 1900); inlet Hurd Pond, Telos and Chamberlain Lakes, and St. Johns River (Kendall \& Gould coll., 1901); Sand Bank Brook (Kendall \& Gould coll., 1902); outlet Chaffin Pond, South Fork of East Branch of Royals River, Mann Brook, Rainbow Lake and Cross Lake Thoroughfare (Kendall coll., 1903); Rainbow Lake (Garland coll., 1903, and Evermann, 1905); common (Atkins coll., 1903); Dixmont (Lee coll., 1903); Cambridge River (Kendall coll., 1905).

34. Conesius plumbeus (Ayassiz). Gray ChußMrnnow; "Dace"; "Dusiry Chub".

Range.-New Brunswick to Lake Superior.

MAINE.-Metallac Brook and Richardson Lake(B. S. N. H., Putnam coll. [1866?]); Freeport (Kendall \& Smith, 1894, and Kendall coll., 1898, 1899, 1900, 1901b, 1902, 1903 and 1904); Varnum Pond (Merrill coll., 1898 and 1899); Presumpscot River (Kendall coll., 1899); Sebago Lake (Kiendall coll., 1908); Telos, Chamberlain, Churchill, Round and Beau Lakes, and Cross Lake Thoroughfare (Kendall \& Gould coll., 1901); Moosehead and Lunkasoos Lakes (Kendall \& Gould coll., 1902); Wild River and Square Lake (Kendall 1903a); northern Maine (Smith, 1903); Square Lake and Cross Lake, and Cross Lake Thoroughfare (Kendall coll., 1903); Oquossoc Lake (Kendall coll., 1904); Umbagog Lake (Kendall coll., 1905); Maine (Kiendall, 1904 and 1908)

ANGUILlid A. The Eels.

35. Anguilla rostrata (LeSueur). "EeL"; Common Eel; "Silver Eel”.

Range.-Salt and fresh water, St. Lawrence River to Gulf of Mexico and West Indies; abundant throughout Mississippi Valley. 
MAINE.-Both fresh and salt water (IVilliamson, 1832); Maine (Holmes, 1862, Putnam \& Pickering, 1865, Jordan \& Evermann, 1896, and Me. S. and S. F. Report, 1898, 1901, 1905, 1907, 1909, 1911 and 1913); Bucksport (Me. F. C. Report, 1869); Damariscotta (Me. F. C. Report, 1870); Eastport (B. S. N. H., Shurtleft coll.); Casco Bay (U.S. N. M., 1873); Leweys Lake (Adams, 1873); Grand Lake Stream (U. S. N. M., 1877); Rangeley Lakes (Me. F. C. Report, 1878); Crooked River (Atkins, 1878); Hancock County (Wasson, 1878); Kennebec (Ne. F. C. Report, 1880); all along the coast in accessible rivers, Penobscot, Kennebec, Wescongus, Harrington, Donnels, Tunk, Sullivan, Medomak, St. Georges and Piscataqua Rivers, and Casco Bay and tributaries (Atkins, 1887); Caseo Bay (Lee, 1885, and Kendall coll., 1892); Western Grand Lake system (Kendall, 1894); Chickawaka Lake (Kendall coll., 1895a); Eastport (Bean, 1881, and Kendall coll., 1893); Freeport (Kendall coll., 1898, 1899, 1900 and 1904, Kendall \& Gould coll., 1900, Smith, 1900, and Pettengill coll., 1900); Cobbosseecontee Lake (Smith, 1901): East Branch of Penobscot River, Matagamon Lake, Hurd Pond and Pokwokamus Deadwater (Kendall \& Gould coll., 1901); Little Sebago Lake (Kendall coll., 1902); Lunkasoos Lake (Kendall \& Gould coll., 1902); Freeport, Green Lake, Floods Pond (Kendall coll., 1903); Penobscot River and Bay (Evermann, 1904); common (Atkins coll., 1903); Moose and Indian Ponds, and Sebasticook River (Bowman coll., 1904); Carry Pond (Kendall coll., 1904); brook tributary to Casco Bay (Evermann, 1905); Matinicus Rock (Norton coll., 1903); Maine (Kendall, 1904 and 1908).

LEPTOCEPHALid N. The Conger Eels.

36. Leptocephalus conger (Limmens). CONGER EEL. 
Range.-Common Cape Cod to Brazil, coasts of Europe, Asia and Africa; not in Eastern Pacific.

MAINve.-Cherryfield (Storer, 1845 and 1846, and Wheatland, 1852); Old Orchard (Norton coll., 1906); Maine (Kendall, 1908). 'Two specimens both of the postlarval or' leptocephalus stage.

Clupeid A. The Herrings.

37. Etrumeus teres (DeKay). Round Herring.

Range.-Cape Cod to Gulf of Mexico.

Maine.-Eastport (Maine newspapers, 1908); Jonesport (Cleveland coll., 1908).

38. Clupea harengus Limmes. IIErring; Common Herring; "English Herring"; "Labrador Herring"; "SARDINE".

Range.-Coasts of Europe and North America, occasionally south to Chesapeake Bay at least.

MaIne.- -Along our coast especially at Herring Gut and eastward" (Williamson, 1832); Maine (Holmes, 1862, Me. F. C. Report, 1869, Me. S. and S. F. Report, 1888, 1894, 1898, 1901, 1903, 1905 and 1907, and Kendall, 1908); Eastport (Verrill, 1871 and 1872 , U. S. N. M., 1872, and Jordan \& Evermann, 1896); Eastport, Lubec, Bluehill, Pembroke, Gott's Island, Boothbay and Georgetown (Boardman \& Atkins, 1875); Bucksport (U. S. N. M., 1878); Hancock County (Wasson, 1878); Eastport and Portland (Bean, 1881); St. Croix River (Atkins, 1887); Casco Bay (Lee, 1885, and Kendall coll., 1892); Eastport and Casco Bay (Kendall coll., 1893); Casco Bay at Small Point (Kendall coll., 1896); Passamaquoddy Bay (Moore, 1897); Passamaquoddy Bay (Rathbun and Wakeham, 1897); Freeport (Kendall coll., 1901b); Porter's Landing Brook (Kendall coll., 1903); Penobscot River and Bay (Evermann, 1904). 
:39. Pomolobus mediocris (Mitchill). HICkORY SHAD; HICKORY JACK.

Range.-Maine to Florida.

MAINE.-Mouths of Kenduskeag and other fresh rivers (Williamson, 1832); Maine (Perley, 1852); Maine coast (Goode, 1884); off Portland (Kendall coll., 18956); Casco Bay at Small Point (Kendall coll., 1896); Freeport (Kendall coll., 1900).

40. Pomolobus pseudobarengus (Witson [?]). ALEWIFE; "ELWIFE" ; "GASPEREAU"; "KYACK" ; "SAWBELLY", ete.

Range.-Nova Scotia, south to the Carolinas.

Marne.-Kennebec (Sullivan, 1795); St. Georges River (Eaton, 1851); Maine (Holmes, 1862, Me. H. C. Report, $1869,1869 a, 1870,1870 a, 1872 a, 1874 a, 1878,1879,1880$, 1882 and 1884, Me. S. and S. F. Report, 1886, 1888, 1891, $18 ! 8,1 ! 01,1 !(0:), 1 ! 05$ and $1 ! 107$, Kendall, 1908, and Atkins, 1871); Eastern, Kenneber and Sandy Rivers, and East Branch of Penobscot (Forster \& Atkins, 1867); Cumberland Mills (Atkins, 1870); Bucksport (U.S. N. M., 1878); Sebasticook, Sandy, East Branch of Penobscot, Dennys, Pennamaquan, Damariscotta, East Machias, Chandlers, Wescongus, II arrington, Tunk, St. (reorges, Androscoggin, Saco, Mousam and Piscataqua Rivers and Patten Stream, West Gouldsboro, Iount Desert, and Caseo Bay and tributaries (Atkins, 1887): Eastport (U. S. N. M., 1872, and Kendall coll., 1893); Maine (Gill, 1873); Hancock County (Wasson, 1878) ; Flag Island (Kendall coll., 1892); off Portland and along coast (Kiendall (•oll., 18956); Simall Point (Lee, 1885, and Kiendall coll., 1896); western tributaries of St. John River and St. Croix River (Rathbun \& Wakeham, 1897); Freeport (Kendall coll., 1898, 1899, 1900 and 1904); Freeport (Pettengill coll., 1900); Lower Penobscot River (Kendall coll., 1902); 
Alamoosook Lake, vicinity of Bradley, Eastern River, Verona, Bucksport, Castine and Stockton Springs (Evermann, 1904); brook tributary to Casco Bay (Evermann, 1905).

41. Pomolobus aestivalis (Mitchill). Alewtife; "Elwife"; "Kítack"; "Blueback".

Range.-Labrador to Florida.

MAIne.-Maine (Williamson, 1832, Holmes, 1862, and Kendall, 1908); Fiddler's Reach (Foster \& Atkins, 1869a); Eastport (U. S. N. M., 1872); Bucksport (U. S. N. M., 1878); Casco Bay (Lee, 1885); St. Croix River (Atkins, 1887); Flag Island (Kendall coll., 1892); Eastport (Kendall coll., 1893); Dennys River (Kendall, 1894); off Caseo Bay and along coast (Kendall coll., 1895b); at Small Point (Kendall coll., 1896); Freeport (Kendall coll., 1898, 1899 and 1900); Wolf's Neck, Freeport (Pettengill coll., 1900); Lower Penobscot River (Kendall coll., 1902); Penobseot River and Bay, and Orland Falls (Evermann, 1904).

42. Alosa sapidissima (Wilson). "SHAD."

Range.-New Brunswick to Florida.

MaInE.-Kennebec (Sullivan, 1795); "In all our rivers until stopped by dams" (Williamson, 1832) ; Maine (Storer, 1859, Holmes, 1862, Me. F. C. Report, 1869a, 1872, 1874, 1880 and 1882, Me. S. and S. F. Report, 1892, 1901, 1903, 1905 and 1907, Atkins, 1871, and Kendall, 1908); St. George River (Eaton, 1851); Kennebec to Augusta, Merrymeeting Bay, Cathance tributary of Kennebec, Sebasticook River, Sandy River, West Branch of Penobscot River and Eastern River (Foster \& Atkins, 1869); Eastport (U.S. N. M., 1872); Casco Bay (U.S. N. M., 1873); Haneock County (Wasson, 1878) ; Portland (Bean, 1881) ; Kennebec, Penobscot, St. Croix, East Machias, Wescongus, Harrington, Mousam and Piscataqua Rivers (Atkins, 1887); Flag Island 
(Kendall coll., 1892); Eastport (Kendall coll., 1893); off coast of Maine (Kendall coll., 1895); Casco Bay (Kendall coll., 1892); Small Point (Kendall coll., 1896); St. Croix (Rathbun \& Wakeham, 1897); Freeport (Kendall coll., 1899 and 1900, and Pettengill coll., 1900); Orland River (Merrill coll., 1899); Penobscot, Verona, Bucksport and Winterport (Evermann, 1904).

43. Breevoortia tyrannus (Latrobe). "Pogr"; Menhaden.

Range.-Nova Scotia to Brazil.

MATNE.- "On our coast up rivers as far as fresh and salt water mix" (Williamson, 1832); Maine (Storer, 1859, Holmes, 1862, Me. F. C. Report, $1869 a$ and 1884, Me. S. and S. F. Report, 1888, 1891, 1892, 1894, 1898, 1901, 1903 and 1905, and Kendall, 1908); Fiddler's Reach (Foster \& Atkins, 1869a); Bluehill Bay, Jonesport, Owl's Head, Schoodic Point, Center Harbor, Isle au Haut, Duck Island, Somes Sound, Patten's and Morgan's Bays, and Sunny and Belfast Bays (Boardman \& Atkins, 1875); Passamaquoddy Bay, Castine, Belfast, Brooklin, Cranberry Isles, Sargentville, Matinicus, New Haven, Monhegan Island, Damariscotta, Pemaquid, Wescongus, Boothbay, Bristol, Round Pond, Waldoboro, Pond Island, Portland and Pine Point (Goode, 1879); coast of Maine (Maddocks, 1878); Hancock County (Wasson, 1878); Casco Bay (Lee, 1885); Freeport (Kendall coll., 1892); Casco Bay at Small Point (Kendall coll., 1896); Freeport (Kendall coll., 1898 and 1900 [young], and Pettengill coll., 1900 [young]); Harraseeket River (Smith, 1902); Penobscot River and Bay (Evermann, 1904).

ENGRAULIDID E. The Anchovies.

44. Anchovia mitchilli (Cuvier \& Valenciennes). Anchovi; Whitebait. 
Range.-Cape Cod to Texas.

MafNe.-Harraseeket River (Kendall coll., 1907).

SALMONIDA. The Sataions.

45. Coregonus quadrilateralis Richardson. Round Whitefish ; "Chivy"; "Chiven".

Range.-Lakes of New England and the Great Lakes northwestward to Alaska, as far south as the Yukon River.

Marne.-Maine (Holmes, 1862, and Kendall, 1904 and 1908); Moosehead Lake (B.S. N. H., Davidson coll. and Denton coll.); Clearwater Pond (Hatch coll., 1890, and Bowdoin College coll., 1900 [1889?]); Farmington (Evermann \& Smith, 1896); Moose Pond [?] (U. S. F. C. coll., 1898 [?]); northern Maine and Clearwater Pond (Smith, 1903); Umsaskis Lake and Cross Lake Thoroughfare (Kendall \& Gould coll., 1901, and Kendall, 1903a); First Debsconeag Lake, and Square and Cross Lake Thoroughfares (Kendall coll., 1903); Industry (Atkins coll., 1903); Eagle Lakes (Evermann, 1905).

46. Coregonus labradoricus Richardson. "WhiteFish"; "GIZZARDFish"; "Whiting"; "Poundeish".

Range.-Recorded from Winnipeg and Great Lakes region and northeastward.

MAIne. - Eagle Lakes, Saint Francis Lakes and Grand Lake (Perley, 1852); Thoroughfare Grand Lake to Pocumpus (Holmes, 1862, and Kendall, 1894, 1904 and 1908); northern and eastern parts of the State, Fish River region, Moosehead, Schoodic and Grand Lakes, and Pocumpus Thoroughfare (Foster \& Atkins, 1869); Nahmakanta Stream (Me. F. C. Report, 1870a); Moosehead Lake (Me. F. C. Report, 1875) Grand Lake Stream (U.S. N. M., 1877); Moosehead Lake (U. S. N. M., 1879); Matagamonsis Lake 
Thoroughfare (Kendall \& Gould coll., 1900); Moosehead and Grand Lakes (Evermann \& Smith, 1896); Grand Lakes (Rathbun \& Wakeham, 1897); Sebago Lake (Daniels coll., 1900, Kennard coll., 1910, Lord coll., 1910, and Kendall coll., 1910); First Debsconeag, Telos, Umsaskis, Glasier and Beau Lakes, and Cross Lake Thoroughfare (Kendall \& Gould coll., 1901, and Kendall, 1903a); northern Maine (Smith, 1903); northern lakes (Atkins coll., 1903); Eagle Lakes (Evermann, 1905).

47. Coregonus stanleyi Kendall. Little WhiteFIsh; S'TANLEY's WhiteFish.

Ronge.-Thus far recognized only from Maine. According to Dr. T. H. Bean, this species occurs in Chateaugay Lake, New York.

MAIne.-Cross Lake Thoroughfare (Kendall \& Gould coll., 1901, and Kendall, 1903a); northern Maine (Smith, 1903); Square Lake and Cross Lake, and Square Lake and Cross Lake Thoroughfare (Kendall coll., 1908); Eagle Lakes (Kendall, 1904 and 1908, and Evermann, 1905).

48. Salmo salar Linncus. "SaLion"; Sea Saliox. Range.-Labrador to Delaware.

MaINe.-Saco River (Sullivan, 1795); Kennebec River (Mitchill, 1818); "is now or has been caught in Saco, Androscoggin, Kennebec, Penobscot and Machias Rivers" (Williamson, 1832); St. Georges River (Eaton, 1851); one of the affluents of Union River (Girard, 1854); Maine (Me. F. C. Report, $1868,1869,1870 a, 1872,1872 a, 1874,1874 a$, $1875,1876,1879,1880,1882,1882$ \% 1883, 1884, 1886, 1888, 18:1, 1892, 1894, 1896, 189tia and 189!, Storer, 1858, Ilolmes, 1862, Foster of A thins, 1868 and 1869, suckley, $187:$; and liendall, 1904 and 1908); Gott's Island (Atkins, 1870a) Eastport (U. S. N. M., 1872, and Kiendall coll., 1893); 
Maine (Atkins, 1871, 1872 and 1873); Rangeley Lakes (U. S. N. M.); Calais River (U. S. N. M.) ; St. George, Medomac, Sheepscot, Kennebec, Androscoggin, Royals, Presumpscot, Saco, Mousam and Piscataqua Rivers, and Richmond's Island (Atkins, 1873) ; Haneock County (Wasson, 1878); Casco Bay (Lee, 1885); Androscoggin, Kennebec, Penobscot, Eastern, Sheepscot, Dennys, St. Croix, East Machias, Wescongus and Piscataqua Rivers, Casco Bay and tributaries (Atkins, 1887); Maine (Me. S. and S. F. Report, 1888, 1908, 1905 and 1907); Dennys River (Kendall, 1894): Casco Bay at Small Point. (Kendall coll., 1896); western tributaries of St. John River and St. Croix River (Rathbun \& Wakeham, 1897); Penobscot Bay and River, Matinicus and Ragged Island, Cranberry Isles, 20 miles southeast of Matinicus, off Frenchman's Bay, 3 miles off Gouldsboro in 20 fathoms, southeast of Mt. Desert in 35 fathoms (Smith, 1898); East Branch of Penobscot, 4 miles below Matagamon Lake (Kendall \& Gould coll., 1900, 1901 and 1902, and Smith, 1902 and 1903); Penobscot River below Bucksport (Kendall coll., 1902); East Branch of Penobscot River, Wissataquoik River, Great Spring Brook, Bowlin Brook and Sebois River (Kendall \& Gould coll., 1902); Katahdin Brook and Aroostook River (Kendall coll., 1903); East Branch of P'enobscot, Wissataquoik and Sebois Rivers (Smith, 1904); Brooksville, Bucksport, Castine, I Iampden, Islesboro, Lincolnville, Ragged Island, Northport, Orland, Orrington, Penobscot, Searsport, South Brewer, Stockton Springs, Prospect, Verona, Winterport and Bangor (Evermann, 1904).

49. Salmo sebago Girard. Fresh-water Salmon; "Black Spot Trout"; "Salmon Trout"; "Siller Lake Trout"; "Landlocked Salmon"; "Schoodic Salmon".

Range.-Peculiar to Maine, New Brunswick and Nova Scotia. A closely related species, $S$. ouananiche, occurs in Quebee waters and is said to be found in Labrador. 
Marne.-Sebago Pond (M., 1832); southern part of State of Maine (Girard, 1853); Sebago Lake (Herbert, 1859, Brackett, 1860, and Putnam \& Pickering, 1865); Maine (Holmes, 1862, Me. F. C. Report, 1868, 1869, 1870, 1874a, $1875,1876,1877,1878,1879,1882 a, 1883,1884,1886,1888$, 1891, 1892, 1894, 1896, 1896a, 1898, 1900, 1903, 1905 and 1907, and Kendall, 1904 and 1908); Presumpscot, Crooked and Songo Rivers, Long Pond and Bear Brook, and Grand Lake and Stream (Foster \& Atkins, 1868); Cumberland Mills (Atkins, 1870); Grand Lake Strenm, Sebago Lake, Reed's Lake, Sebec Lake and Union River (Hamlin, 1873); Grand Lake Stream (U.S. N. M., 1872a); Grand Lake and Union River (Adams, 1873); Sebec Lake (U. S. N. M., $1873 a)$; St. Croix and Union Rivers, and in the waters of northern Maine generally, Schoodic or Grand Lakes (Hallock, 1873); southern part of the State of Maine, Union River and St. Croix River (Suckley, 1873); Schoodic or Grand Lake waters, Sebec Lake, Ship Pond, Long Pond, Reed's Pond, Sebago Lake and Presumpscot River '(Stilwell \& Stanley, 1874); Sebago Lake (U.S. N. M., 1875 $)$ ): Sebago Lake, Union River and the St. Croix system, Big Lake, West Musquash, Grand Lake and Stream, Pocumpus, Sysladobsis and Sysladobsissis Lakes and Stream, Scragley Lake and Pleasant Lake (Atkins, 187\&): Crooked River (Atkins, 1880): Grand Lake Stream (U.S. N. M., 1877); (Baird, 1880); Sebago, Grand Lakes, Sebec Pond and Schoodic Lake (Bean, 1881); Rangeley Lakes (U.S. N. M., 1880); basins of Presumpscot, Sebec, Penobscot, Union and St. Croix Rivers (Atkins, 1884a, $188 \pm b$ and 1884c); Pocumpus, Chipedneck and Pleasant Lakes, Grand Lake, W est Musquash Lake, Rangeley Lakes and IVeed Pond (Atkins, 1884c); Schoodic Lake (U. S. N. M., 1884); Grand Lake Stream (Kendall, 1894); Sebago Lake (Jordan \& Evermann, 1896, and Kendall coll., 1906 to 
1912 incl.); St. Croix system and Grand Lake (Rathbun \& IVakeham, 1897); Presumpseot River (Kiendall coll., 1898); Sebago Lake, Presumpscot River, Thomas Pond and a tributary of Cobbosseecontee Lake (Kendall coll., 18:99 ); Sebago Lake, Thomas and Panther Ponds, and Presumpscot River (Smith, 1900); Lake Auburn (Merrill coll., 1899); Cobbosseecontee Lake (Smith, 1901); Sebec Lake (Smith, 1902); Songo and Presumpseot Rivers, and Sebago Lake (Kendall coll., 1901a); Cross Lake Thoroughfare (Kendall \& Gould coll., 1901); Presumpscot River (Kendall coll., 1902 and 1903); Lunkasoos Lake (Kendall \& Gould coll., 1902); Sebago Lake, Presumpscot River, Green Lake, Branch Pond, Floods Pond, Square Lake, Cross Lake and Eagle Lake Thoroughifares, Oquossuc Lake, Rangeley and K'émebago Streams (Kendall coll., 1903); many lakes (Atkins coll., 1903); Moose Pond and Sebasticook River (Bowman coll., 1904); Pierce Pond (Kendall coll., 1904); Eagle Lakes (Evermann, 1905); L'mbagog Lake (Kendall coll., 1905).

50. Salvelinus namaycush (Walbaum). "Togue": "Lake Trout"; "Laker"; "Salmon Trout"; "Touladi".

Range.-Widely distributed, being recorded from Great Lakes, northern New York, New Hampshire and Maine, the head waters of Columbia and Frazer Rivers, streams of Vancouver Island and north to the Arctic Circle.

MAINE.-In all our larger lakes and ponds (Williamson, 1832, and Hamlin, 1853 [?] and 1903); Maine (Perley, 1852, Me. F. C. Report, 1869, 1875, 1878, 1905, 1909, 1911 and 1913, and Kendall, 1904 and 1908); many lakes of Maine, Eagle Lakes at head of Fish Liver, St. Croix Grand Lake and Tunk Lakes (Holmes, 1862); 'Thompson's Pond [?] (Putnam, 1866a); Grand Lake (Suckley, 1873); Tunk Lakes, Thompson's Pond, Lakes of the Upper Kennebec, Penobscot and St. John Rivers and the St. Croix system, and Wilton 
Pond (Foster \& Atkins, 1868); Grand Lake Stream (U. S. N. 11., 1872a); Moosehead and St. Croix (Hallock, 1873); Grand Lake (Adams, 1873, and Kiendall, 1894); Phillips Pond (U.S. N. M., 1874c) ; Schoodic Lake (Sargent, 1895); Clearwater Pond (Hatch, 1895) : lakes of St. Francis River and st. Croix system (Riathbun \& Wakeham, 1897); Hurd Pond, Matagamon Lake, Webster, Telos, Chamberlain, Eagle, Churchill and Beau Lakes (Kendall \& Gould coll., 1901); Moosehead Lake (B. S. N. H., Davidson coll., Goode, 1879, and Kendall \& Gould coll., 1902); Hurd Pond (Smith, 1903); Debsconeag Lake and Square Lake (Kéndall coll., 1903) : many lakes (Atkins coll., 1903); West Carry Pond (Kendall coll., 1904); Eagle Lakes (Evermann, 1905).

51. Salvelinus fontinalis (Mitchill). "TrouT"; "Brook Trout"; "Speckled "Trodt"; "SouAretail"; "RELAPUT”.

Range.-Occurs northward to Labrador, west to Minnesota and southward in the Alleghenies to the head waters of the Savannah, Chattahoochee, Catawba, and the French Broad.

MAINE. - "Fresh waters, particularly the Androscoggin" (Williamson, 1832); Moosehead Lake (Hamlin, 1856, and lineeland, 1857); Maine (Storer, 1858, Holmes, 1862, Me. F. C. Report, 1869, 1870a, 1875, 1878, 1879, 1880, 1884, $1894,1896,1896 a, 1899,1900,1903,1905,1907,1908$, 1909, 1911 and 1913, and Kendall, 1904 and 1908); all over the state in gravelly, pure streams, Umbagog system of lakes, Moosehead Lake, Grand Lake Stream, Great Pond, Cobbosseecontee Lake, Silver Lake in Sidney and Manchester Forks (Foster \& Atkins, 1868); Grand Lake Stream (Atkins, $1870 a$, and Suckley, 1873); Lake Richardson, Moosehead lake, Umbagog, Rangeley and other feeders of the liennebec and Androscoggin Rivers in Maine (Hallock, 1873); Crooked River (Atkins, 1880); Thompson Pond (Bowdoin 
College coll., 1900 [1883]) ; Schoodic Lakes (U. S. N. M., 1884); Weld Pond (Atkins, 188te); Casco Bay (Lee, 1885); brook in Brunswick ( Bowdoin College coll., 1893, and Adams, 1873 ) ; MIt. Desert Island (Willard, 1895); Upper St. John and St. Croix system (Rathbun \& Wakeham, 1897); Dennys River (Kendall, 1894); Freeport (Kendall coll., 1898, 1899, 1900, 1901b, 1902 and 1903); Muddy River (Kendall coll., 1898); tributary of Panther Pond, Thomas Pond and Presumpscot River (Kendall coll., 1900a); Cobbosseecontee Lake (Smith, 1901); tributary of Cobbosseecontee Lake (Kendall, 1899a) ; Sebago Lake (Smith, 1900); Rangeley Lake, Kennebago Stream and East Branch of Penobscot (Kendall \& Gould coll., 1900); inlet Hurd Pond, inlet Second Debsconeag, Fourth Debsconeag, Daisy Pond, Second IIurd Pond and outlet, Southard's Pond, Rainbow Lake, East Branch of Penobscot below Matagamon dam, Bill Fish Brook, Matagamon, Matagamonsis, Webster Lake and Brook, Chamberlain Lake, Allagash liver below Chamberlain Lake, Eagle and Umsaskis Lakes, St. John River, Glasier and Beau Lakes and St. Francis River (Kendall \& Gould coll., 1901); Presumpscot River (Kendall coll., 1902); Rainbow Lake (Smith, 1903); Sand Bank Brook, Wissataquoik River, Little and Great Spring Brooks, Little Sebois Stream, Seboís River, Lunkasoos Lake and Bowlin Pond inlet and outlet (Kendall \& Gould coll., 1902); Presumpscot River, Thomas Pond, East Branch and South Fork of East Branch of Royals River, Porter's Landing, Carter, Joe True, Hillside and Harvey Brooks, Simpson and High Gulley Brook, Mann Brook, Winkempaugh Brook, Floods Pond, Rainbow Lake, Little Beever Pond, Daisy Brook, Second Hurd Pond, Square Lake, Square Lake Thoroughfare, Goddard and Little Goddard Brook, Birch Brook, Mud Brook, Eagle Lake and Cross Lake Thoroughfare, Rangeley and Kennebago Streams (Kendall coll., 1903); common (Atkins coll., 1903); 
Moose Pond and Sebasticook River (Bowman coll., 1904); Freeport, Rangeley Stream, Oquossoc Lake, Kennebago Stream, Floods Pond, Rainbow Lake and Carry Ponds (Kendall coll., 1904); Eagle Lakes (Evermann, 1905); Umbagog lake ( Kendall eoll., 1905); Belgrade Lake (Kendall, 1908): Sebago Lake (Kiendall coll., 1911).

52. Salvelinus aureolus Bean. GoLdeN Trout; "Silver Trout".

Range._Recorded from Sunapee Lake and Dan Hole Pond in New Hampshire, Averill Pond, Vermont, and Floods Pond in Maine. Closely related species oceur in Canada and northward to the Arctic Circle, Greenland and in Europe.

MAINE.-Floods Ponds (U. S. F. C. coll., 1894, Jordan \& Evermann, 1896, Me. F. C. Report, 1898, Kendall coll., 1903 Evermann, 1905, and Kendall, 1904 and 1908).

53. Salvelinus oquassa ( Girard). "BLUEBACK"; "BLUEBACK TrouT".

Range.-So far as known, peculiar to the Rangeley Lakes in Maine (where it is believed to be extinct), although a similar fish of Rainbow Lake, Maine, is provisionally identified in this paper as this species.

Maine.-Oquossoc Lake (Girurd, 1853); Nooselucmagumtic Lake, liennebago Stream and "()quossa” I alie (Hitchcock, 1862); Maine (Holmes, 1862, and Me. F. C. Report, $1869,1874 a, 1875$ and 1878); Rangeley and Mooseluemaguntic Lakes (Foster \& Atkins, 1868); Rangeley Lakes (Suckley, 1873, Adams, 1873, Stilwell \& Stanley, 1874a, U. S: N. M., 1874, and Jordan \& Evermann, 1896); Rangeley Lakes (Bowdoin College coll., 1900 [1884], and U. S. N. M., 1884); Rangeley Lake (U.S. N. M., 1873b); Kennebago Stream (Kendall \& Gould coll., 1900, and Kendall coll, 1904); Rangeley Lakes (Smith, 1902); Rangeley 
Stream (Kendall coll., 1903 and 1904); Rangeley Lakes (Atkins coll., 1903); Rainbow Lake (Garland coll., 1903 and 1904, Evermann, 1905, and Kendall, 1908).

\section{ARGEN'Tinid A. The Shelts.}

54. Osmerus mordax (Mitchill). "SMelt"; "SALT Water Simelt"; "Fresh Water Sielt".

Range.-New York to Gulf of St. Lawrence; permanent resident of some lakes in Maine and New Hampshire; Lake Champlain and Memphramagog.

MAINE.- "Caught in abundance after March in our rivers" (Williamson, 1832); Maine (Ḱneeland, 1857, Storer, 1846, 1858 and $1867 a$, Holmes, 1862, Me. F. C. Report, 1868, $1869,1870,1879,1880$ and 1896, Me. S. and S. F. Report, 1886, 1888, 1891, 1894, 1897, 1898, 1901, 1903, 1905, 1907 and 1911, and Kendall, 1904 and 1908); St. Georges River (Eaton, 1851); ponds in Harrison and Belgrade (Foster \& Atkins, 1868); Eastport (U. S. N. M., 1872); Casco Bay (U. S. N. M., 1873); Industry (U. S. N. M., 1874); Belgrade Mills (U. S. N. M., 1875); Sebago Lake, Union River and the St. Croix systems, Big Lake, West Musquash Lake, Grand Lake and Grand Lake Stream, Pocumpus Lake, Sysladobsis and Sysladobsissis Lakes and Stream, Scraggley Lake and Pleasant Lake (Atkins, 1878); Bucksport (U.S. N. M., 1878); Hancock County (Wasson, 1878); Portland (Bean, 1881); Weld Pond (Atkins, 1884a); above Bay Ridge, on Androseoggin River, and Belgrade, Bear Brook, Long Pond, Norway Lake, Lpper Dobsey or Sysladobsissis Lake, and rivers and creeks along the coust (Mather, 1885); St. Croix, East Machias, Chandler's, Wescongus, Harrington, Narraguagus, Tunk, Sullivan's, Patten, P'enobscot, Bagaduce, ()rland, Medomak, St. George's, Damariscotta, Sheepscot, Kiennebec, New Meadows, Saco, York and Piscataqua Rivers, and West Bay, 
Casco Bay and tributaries, Robinston and Deer Isle (Atkins, 1887); Great Pond (Bowdoin College coll., 1900 [?]) ; Eastport (Kendall coll., 1893); Grand Lake Stream and Pennamaquan Lake (Kendall, 1894); Meddybemps Lake (Kendall coll., 1910); Passamaquoddy Bay (Rathbun \& Wakeham, 1897) ; North Bridgton (Bowdoin College coll., 1900 [1895]) ; Small Point, Casco Bay (Lee, 1885, and Kendall coll., 1896); Sebago Lake (Kendall coll, 1898); Little Sebago Lake (Ḱendall coll., 1898 and 1900a); Lake Auburn, Duck Pond, Taylor Pond and Sebago Lake (Smith, 1900 ) ; Swan Lake (Merrill coll., 1898 and 1899); Freeport (Kiendall coll., 1899 and 1900, and Pettengill coll., 1900); Siebago and Little Sebago Lakes (Smith, 1!02) ; Songo River and Panther Pond (Kendall coll., 1901a); Harraseeket River (Kiendall coll, 1901b); Presumpscot River (B. S. N. H., Putnam coll.); Freeport, Presumpscot River and Little Sebago Lake (Kendall coll., 1902); Sebago Lake, Porter's Landing Brook, High Gully Brook, Green Lake, Mann Brook, Branch Pond, Kenduskeag, Square and Cross Lakes (Kendall coll., 1903) ; Belgrade (Atkins coll., 1903); Penobscot River and Bay (Evermann, 1904); Floods Pond (Kendall coll., 1904); brooks tributary to Casco Bay, Freeport and Eagle Lakes (Evermann, 1905); Umbagog Lake (Kendall coll., 1905).

\section{Osmerus spectrum Cope. Wilton Simet.}

Range.-So far as known peculiar to Wilson or "Wilton" Pond, in IVilton, Maine.

MAINE._Wilton" Pond, Kennebec County (Cope, 1870, Jordan \& Evermann, 1896, and Kendall, 1908); Industry (U.S. N. M., 1874b); Wilton (Atkins coll., 1903, and Kendall, 1908).

56. Osmerus abbotii Cope. CobBossenconten Sireit. 
Range.-Thus far recognized only from a limited area in Maine.

MaINE.-Cobbosseecontee Lake (Cope, 1870, Jordan \& Evermann, 1896, Smith, 1901, Berry coll., 1903, and Kendall, 1908); ponds in Monmouth and Cochnewagan Pond (Foster \& Atkins, 1868); Sabattus Pond (Merrill coll., 1898 and 1899); Winthrop (Atkins coll., 1903); Moose Pond and Sebasticook River (Bowman coll., 1904).

57. Argentima silus (Ascanius). Argentine.

Range.-Northern Europe; occasionally on our northern coast.

Maine.-Belfast and Biddeford Pool (Goode \& Bean, 1896, and Kendall, 1908); off the coast of Maine (Jordan \& Evermann, 1896); off Mt. Desert Rock (Welsh coll., 1912); off Petit Manan Point (Welsh coll., 1913).

\section{ESOCID A. The Pikes.}

\section{Esox reticulatus (Le Sueur). "Pickerel".}

Range.-Maine to Florida and Louisiana, west to Arkansas.

Maine.-Kennebec waters, first brought to Penobscot and put in Davis Pond in Eddington, where they have increased surprisingly (Williamson, 1832); Maine (Storer, 1858 and 1867, Holmes, 1862, Foster \& Atkins, 1868, Putnam \& Pickering, 1865, Me. F. C. Report, 1868 and 1870, and Kendall, 1904 and 1908); Leweys Lake (Adams, 1873); Umbagog Lake (Kendall coll., 1883 and 1905); Androscoggin River (Kendall coll., 1883); Thompson Pond (Bowdoin College coll., 1900 [1883]); Weld Pond (Atkins, 1884c); Umbagog Lake (Kendall coll., 18s7); brook in Brunswick (Bowdoin College coll., 1900 [1893]); Grand Lakes (Rathbun \& Wakeham, 1897 ); Boyden Lake, Meadow Brook, Pennamaquan Lake and River, Meddybemps Lake, Dennys River, Grand Lake 
Stream, St. Croix River and Magurrowock Stream (Kendall, 1894); Chickawaka Lake and outlet (Kendall coll., 1895a); Freeport (Kendall coll., 1898); Sebago and Little Sebago Lakes, Songo and Presumpscot Rivers (Kendall coll., 1898, 1899 and 1900a); Cobbosseecontee Lake (Smith, 1901); Rattlesnake and Thomas Ponds, Cobbosseecontee Lake and tributaries, and Maranocook Lake (Kendall coll., 1899a); Sebago Lake (Smith, 1900); Thomas Pond (Kendall coll., (1900); Sebec Lake (Kendall \& Gould coll., 1900); East Branch of Royals River ( Kendall coll., 1901h); Little Sebago Lake, East Branch of Royals River, Winkempaugh Brook and First Debseoneag Lake (Kendall coll., 1903 ); "common" (Atkins coll., 1903); Moose and Indian Ponds and Sebasticook River (Bowman coll., 1904); Ambajejus Falls, and First and recond Debsconeag Lakes (Kendall \& Gould coll., 1901) ; Little Sebago Lake (Kendall coll., 1902); Wissataquoik Deadwater (Kendall \& Gould coll., 1902); Pierce Pond (Kendall coll., 1904); Umbagog Lake (Kendall coll., $1905)$.

PQECILIDA. THE KILLIEISHes.

59. Fundulus heteroclitus (Limcens). MUмMIChoG; "Minny"; "Salt Water Minnow"; "Tomcod".

Range.-Gulf of St. Lawrence to Texas.

Maine.-Maine (Holmes, 1862, Gill, 1873, Jordan \& Evermann, 1896, and Kendall, 1908); Eastport (U.S. N. M., 1872); Casco Bay (U. S. N. M., 1873, and Lee, 1885); ponds near New Meadows (Bowdoin College coll., 1900 [?] ); Freeport (Kendall coll., 1892, 1898, 1899, 1900 and 1904, and Pettengill coll., 1900, 1901b, 1902 and 1903); Eastport (U. S. N. MI., 1892, and Kendall coll., 1893); . Penobscot River and Bay (Evermann, 1904); brook tributary to Casco Bay (Evermann, 1905). 
60. Fundulus diaphanus (Le Sueur). "Shore Fish"; "Fresh Water Minnow"; "Flathead".

Range.-New Brunswick to North Carolina, west to the Mississippi River.

MAINE.-Androseoggin River at Brunswick (Bowdoin College coll., 1900 [1873]); brook in Brunswick (Bowdoin College coll., 1900 [1893]); Boyden and Pennamaquan Lakes, and Grand Lake Stream (Kendall \& Smith, 189t, and Kendall, 1894); Chickawaki Iake (Kendall eoll., 1895a); Iake Auburn, Craig's Pond, Cobbosseecontee Lake and Sitillwater River (Merrill coll., 1898 and 1899); Maranacook Lake in Winthrop (Kendall coll., 1899a); Lake Auburn and Matagamonsis Lake (Kendall \& Gould coll., 1900); Matagamon Lake and neighboring waters (Smith, 1902); Hurd Pond and Cross Lake Thoroughfare (Kendall \& Gould coll., 1901); Floods Pond and outlet (Kendall coll., $1902 b$ and 1904); Orland (Atkins coll., 1903); Maine (Kendall, 1904 and 1908).

\section{BELONID RE. 'THE BHLL-FISHEs.}

61. 'Tylosurus marinus (Walbaum). "BILL-FISH"; GAR-Fish; Silver Gar.

Range.-Maine to Texas.

Maine.-Maine (Williamson, 1832) ; Wolf's Neck, Freeport (Pettengill coll., 1893 [?], and Kendall, 1908).

HEMIRHAMPHIDA. THE HALFBEAKS.

62. Hyporhamphus roberti (Cuvier of Trenciennes). HALFBEAK; "SKIPJACK".

Range.-Cape Cod to Gulf of Mexico; also on Pacific coast.

Marne.-Machias waters (Powers coll., 1913); Casco Bay (Copeland coll., 1913). 
SCOMBERESOCIDA. The Needefishes.

63. Scomberesox s a rus (Walbaum). NeedLeFISH ; "BILL-FISH".

Range.-Temperate parts of Atlantic Ocean, especially north of Cape Cod, and France.

MAINE._Monhegan (Goode \& Bean, 1879) ; Small Point, Caseo Bay (Kendall coll., 1896); Old Orchard (Bowdoin College coll., 1900 [1898]); Maine (Kendall, 1908).

Gas'TEROSTEID A. The Sticktebacks.

64. Eucalia inconstans (Kirtland). "BRook STICKLEBACK".

Range.-Aside from one locality in Maine and from New Brunswick, this species has not been recorded east of New York and Montreal. Its former recorded range is from New York to Kansas and northward to the Saskatchewan, south to Central Ohio and Illinois.

Mance.-C'Tributary of Cobbosseecontee Lake (Kéndall coll., 1899a, Smith, 1901, and Kendall, 1903a and 1908).

65. Pungitius pungitius (Linnceus). NINE-SPINed Stickleback; "PIn-Fish"; "HornpouT".

Range.-Lndoubtedly one of the most widely distributed of northern species, occurring in both fresh and salt water in the northern part of Europe, and from the Arctic Seas to New York and westward and northward to the Saskatchewan and Alaska.

Mane.-Kennebec County (Storer, 1837 and 1846); Maine (Holmes, 1862, and Kendall, 1908); Eastport (B. S. N. H., Emerton coll., U. S. N. M., 1872, and Adams, 1873); Casco I3ay (Lee, 1885); brook in Brunswick (Bowdoin College coll., 1900 [1890]); Grand Lake Stream (Kendall, 1894); Freeport (Kendall coll., 1898, 1899, 1900, 
1901b, 1902 and 1903, and Pettengill coll., 1900); Lake Auburn, Bill Fish Brook and Matagamonsis Lake (Kiendall \& Gould coll., 1900 and 1901); Cross Lake Thoroughfare (Kendall \& Gould coll., 1901); Sebois River (Kendall \& Gould coll., 1902); Porter's Landing Brook and Cross Lake Thoroughfare (Kendall coll., 1903); Bangor (Lee coll., 1903); brook tributary to Casco Bay (Evermann, 1905); Sebago Lake (Kendall coll., 1908 and 1909).

66. Gasterosteus aculeatus Limncus. StickLEBack; "Sickleback"; Three-Spined Stickleback ; "PinFish"; "HornpodT"; "Ghostere"; "ThorNfish"; “ТhorNBACK".

Range.-Northern Europe; Labrador to New Jersey.

MAINE.-Maine (Williamson, 1832, Holmes, 1862, and Kíendall, 1908); Eastport (U. S. N. M., 1872); Casco Bay (U. S. N. M., 1873, and Lee, 1885); tributary of Casco Bay (Bowdoin College coll., 1900 [1877]); Bay of Fundy (Bowdoin College coll., 1900 [1891]); Eastport (Kendall coll., 1893); pond near New Meadows River (Bowdoin College coll., $1900[?])$; off coast of Maine (Kendall, 1895b); Rockland (Kendall coll., 1895); Small Point (Kendall coll., 1896); Freeport (Kendall coll., 1898, 1899, 1900, 1902, 1903 and 1904, and Pettengill coll., 1900); High Gully Brook (Kendall coll., 1903); brook tributary to Casco Bay (Evermann, 1905).

67. Gasterostens atkinsii Bean. "H'RESH WATER Stickleback"; Stickleback.

Range.-Maine, New Brunswick, and Quebec.

MAINE.-Grand Lake (Adams, 1873); Grand Lake Stream (Bean, 1879); Schoodic Lakes (Eigenmann, 1886); Maine (Jordan \& Evérmann, 1896, and Kendall, 1908); Lake Auburn and Cobbosseecontee Lake (Merrill coll., 1898 and 
1899); tributary of Cobbosseecontee Lake (Kendall coll., $1899 a$ ); Bill Fish Brook and Matagamonsis Lake (Kendall \& Gould coll., 1900, and Smith, 1902); Bill Fish Brook, Matagamonsis, IVebster, Telos, Chamberlain, Eagle, Churebhill, Glasier and Beau Lakes, Allagash River and Cross Lake Thoroughfare (Kendall \& Gould coll., 1901); Moosehead Lake (B. S. N. H., Davidson coll., and Kendall \& Gould coll., 1902); northern Maine and Grand Lake Stream (Smith, 1903); Floods Pond, Cross Lake Thoroughfare and Salmon Lake (Kendall coll., 1903); Grand Lake Stream and Orland (Atkins coll., 1903); Floods Pond (Kendall coll., 1904).

68. Gasterosteus bispinosus* Walbaum. TwoSPINed SticklebAck.

Range.-Newfoundland to New York.

Manne.-Bay of Fundy (Bowdoin College coll., 1900 [1x:11]); off Seguin Islanrl (Kendall coll., 1895b); creek at Small Point, Casco Bay, and off Monhegan Island (Kiendall coll., 1896); off coast of Maine (Jordan \& Evermann, 1898 a) ; Porter's Landing (Kendall coll., 1898, 1899, 1900 and 1903, and Pettengill coll., 1900); New Meadows River (Bowdoin College coll., 1901); Maine (Kendall, 1903a, and Kendill, 1908).

69. Apeltes quadracus (Mitchill). Four-SPIned STICKLEBACK.

Range.-Maine to Virginia.

MATNe.-Eastport (U. S. N. M., 1872); Casco Bay (U. S. N. M., 1873); Chickawaka Lake and outlet (Kendall coll., 1895a, and Smith \& Kendall, 1898); Maine (Jordan \& Evermann, 1896, and Kendall, 1908); Freeport (Kendall coll.,

*Not of Jorian \& Evermann; but $G$, bicculentus Cuvier \& Valenciennes, $G$. Ithecetlandi Putnam, (r. Illeduncrulus Kendall. 
$1898,1899,1900,1901 h, 1902$ and 1903); brook tributary to Casco Bay (Evermann, 1905).

SYNGNATHID ג. The Prpefishes.

70. Siphostoma fuscum (Storer). "PIPEFISH".

Range.-Nova Scotia to Virginia.

MAine.-Casco Bay (U. S. N. M., 1887, Lee, 1885, Bowdoin College coll., 1900 [?], and Kendall coll., 1898 to 1900); Eastport (U. S. F. C. coll., 1890, and Kendall coll., 1893); off coast (Kendall coll., 1895l, and Kendall, 1896i); Freeport (Kendall coll., 1898, 1899 and 1900, and Pettengill coll., 1900): Scarborough (H. Ellis, in P. S. N. H. coll.); Maine (Kendall, 1908).

A'THERINID A. The Silversides.

71. Menidia menidia notata (Mitchill). SILvERside; "Brit"; "Young Silelt"; "Green Sielt"; Sand SMelT ; "CAPELIN".

Range. - Nova Scotia to Virginia.

Maine.-Maine (Holmes, 1862, Gill, 1873, and Kendall, 1908); Casco Bay (U. S. N. M., 1873); Orland (Bean, 1881); Casco Bay (Lee, 1885); Casco Bay and Freeport (Kiendall coll., 1892, 1898, 1899 and 1900, and Kendall, 1902a) ; Eastport (Kendall coll., 1893).

\section{MUGILID无. The MUlLets.}

72. Mugil Cephalus Linnceus. "Mullet"; Comiron Mullet; Striped Mullet.

Range.-Coasts of Southern Europe and Northern Africa; Atlantic coast of America from Cape Cod to Brazil; Pacific coast, Monterey to Chili. 
Maine.-Freeport (Pettengill coll., 1900, and Kendall, 1903 a and 1908): Harraseeket River (Smith, 1902); Clapboard Island (Ralph H. Norton coll., 1908).

AMnODYTide. The Sand Launces.

73. Ammodytes americanus DeKay. LANT; SANd LaUnCe; "SANd Eel".

Range.-Newfoundland to Cape Hatteras.

MaIne.-Eastport (Kendall coll., 1893); Small Point (Kendall coll., 1896); Casco Bay (Lee, 1885, and Pettengill coll., 1900); Saco Bay (Norton); Harpswell (Kingsley, in P. S. N. H. coll.); Maine (Kendall, 1908).

SCOMBrida. The Mackerels.

\section{Scomber scombrus Linnous. "MLACKEREL."}

Range.-North Atlantic; north to Norway and Labrador, south to Spain and Cape Hatteras.

MATNE.-Off Mount Desert Rock and other places on our coast (Williamson, 1832); Maine (Storer, 1846, 1853 and 1867 a , Holmes, 1862, Me. F. C. Report, 1869, Me. S. and S. F. Report, 1886, 1891, 1892, 1898, 1901, 1903, 1907, 1909, 1911 and 1913, Goode, Collins \& Clark, 1884, and Kendall, 1908); Boone Island Ledge (Atwood, 1865); Eastport (U. S. N. M., 1872); Casco Bay (U. S. N. M., 1873); Hancock County (Wasson, 1878, and Collins \& Rathbun, 1887); Flag Island, Casco Bay (Lee, 1885, and Kendall coll., 1892); off Mount Desert, Monhegan, Casco Bay and Boone Island (Kendall coll., 18956); Small Point (Kendall coll., 1896); Casco Bay (Kéndall coll., 1899, 1900, 1908 and 1912); Penobscot River and Bay (Evermann, 1904). 
75. Scomber colias Gmelin. Chub Mackered: "Hardhead"; "Spanish Mackerel".

Range.-Atlantic coast, north to England and Maine, and the Mediterranean.

MAINE.-Maine (Holmes, 1862, Jordan \& Evermann, 1896, and Kendall, 1908); Cash's Ledge (Atwood, 1865); off Casco Bay (Kendall coll. and Bowdoin College coll., 1900 [1893], and Kendall coll., 1895b); Small Point, Casco Bay (Kendall coll., 1896).

76. Thunnus thynnus Limoers. "H o R E Mackerel"; Tunny; Tuna.

Range.-Pelagic, on all warm coasts and north to Gulf of St. Lawrence and Scandinavia.

Marne.-Maine (Williamson, 1832, Holmes, 1862, and Kendall, 1908); common on our coast as far east as Penobscot Bay, and Brooklin (Boardman \& Atkins, 1875); Mount Desert to Gloucester (Maddocks, 1878); Eastport (Kendall coll., 1893); Passamaquoddy Bay (Moore, 1897).

77. Sarda sarda (Bloch). "Bonito".

Range.-North to England; Newfoundland; San Francisco and Japan.

MAINE.-Harpswell (Bowdoin College coll., 1900 [1890], and Kendall, 1908.).

75. Scomberomorus maculatus (Nitehith). SpasISH MACKEREL.

Range.-Both coasts of North America; north to Cape Ann, south to Brazil.

MaIne.-Maine (Storer, 1853 and $1867 a$, Holmes, 1862, and Kendall, 1908); Monhegan (Goode \& Bean, 1879). 
79. 'Trichiurus lepturus Linnous.

Range._Warm seas; chiefly western Atlantic, north to Virginia ; oceasionally in lower California.

MAINE.-Monhegan (Storer, 1853, and Kendall, 1908).

XIPHIIDA. 'THE SWORDFISHES.

80. Xiphias gladius Linnceus. "SWORDFISH."

Range.-Atlantic Ocean, both coasts; Newfoundland Banks and Cape Britton to Cuba; southern Europe; also Pacific.

MAINE.-Off Mount Desert (Williamson, 1832) ; off Portland (Goode, 1884); off Boone Island, Cod Ledge, off Cape Elizabeth, near Seguin, and off Monhegan (Willard, 1885); Casco Bay (B. S. N. H., Davidson coll.); Gouldsborough, at Schoodic Point, 1912 (fide, Fred Racklift); near Cape Elizabeth lightship, Aug. 12, 1908, and Cod Ledge, July 22, 1911 (fide, E. D. Rackliff); Maine (Me. S. and S. F. Report, 1867, 1898, 1901, 1905 and 1907, and Kendall, 1908).

CARANGIDA. The Pampanos.

81. Naucrates ductor (Linnaus). Pilotrish.

Range.-All warm seas, Cape Cod to West Indies.

Maine.-Near Seguin Island (Bowdoin College coll., 1900, and Kendall, 1908).

82. Vomer setapinnis (Mitchill). MoOnfish; SHINIR.

Range.-Tropical; both coasts of America, Maine to Brazil, and Cape San Lucas to Brazil; west coast of Africa.

Malne.-Casco Bay (P.S. N. H.); Saco (Bachelder, 1845, and Storer, 1846, 1853 and 1867 $\alpha$ ); Maine (Holmes, 1862, Gill, 1873, Jordan \& Gilbert, 1883, Jordan \& Evermann, 1896, and Kendall, 1908). 
83. Selene vomer (Linncus). LOOKDown; HoRSEHEAD; MOONFIsh.

Range.-Tropical America on both coasts, from Cape Cod to Brazil, and lower California to Peru.

MaIne.-Casco Bay (Bowdoin College coll., 1900 [1880], and U. S. N. M., 1887); Maine (Kendall, 1908).

POMATOMIDA. The Bluefishes.

8t. Pomatomus saltatrix (Limuens). "Bludefish"; Skip-Jack; Horse Mackerel; Tatlor; Salt-water TAILOR.

Range.-Atlantic and Indian Oceans.

Matne.-Maine (Storer, 1853 and $1867 a$, Holmes, 1862, and Kendall, 1908); Casco Bay (U. S. N. M., 1873); from Georgia to Mt. Desert, Portland, Boothbay, and Kennebec River (Boardman \& Atkins, 1875); off Seguin (U. S. N. M., 1879); Cape Florida to Penobscot Bay (Goode, 1884); Small Point, Casco Bay (Lee, 1885, and Kendall coll., 1896); Harraseeket River, Freeport (Kendall coll., 1900 [young]); Wolf's Neck, Freeport (Pettengill coll., 1899, 1900 [young]); Harraseeket River (Smith, 1902); Sturdevant's Island (Kendall coll., 1908 [young]); Scarborough (1891, E. B. Pillsbury).

CENTROLOPHid A. The Rudderfishes.

85. Palinurichthys pereiformis (NFtchill). RudDERFISH ; LOGFISH.

Range.-Maine to Cape Hatteras.

MAINE.-Maine (Gill, 1873, Jordan \& Evermann, 1896, and Kendall, 1908). 
LAMPRIDA. The Moonfishes.

86. Lampris Iuna (Gmetin). OPAH ; "Moonfish"; JERUSALEN HADDOCK.

Range.-Open waters of Atlantic and Pacific; taken off Newfoundland, Cape Sable and Maine.

MAINE. - Maine (Jordan \& Evermann and Goode \& Bean, 1896, and Kendall, 1908).

S'TROMA'TEIDA. 'T'HE ButTerfishes.

87. Poronotus triacauthus (Peck). "Butterifisu": "DOLLARFish"; SHiner.

Range.-Nova Scotia to Florida.

Maine.-Piscataqua River (Peck, 1804); Maine (Williamson, 1832, Holmes, 1862, Gill, 1873, Goode, 1884, Jordan \& Evermann, 1896, and Kendall, 1908); Eastport (U. S. N. M., 1872); off Seguin (U.S. N. M., 1879); Eastport and Portland (Bean, 1881); Casco Bay (U. S. N.M., 1887, and Lee, 1885); off Casco Bay (Kiendall coll., 1896); Small Point, Casco Bay (Kendall coll., 1896); Sturdevant's Island, Casco Bay (1909).

\section{CEN'TRARCHIDA. 'THE SUNFIsHES.}

88. Lepomis amitus (Limnous). RED SUNFISH : LONG-EARED SUNFISH; "QUIVER"; "ROACH".

Range.-New Brunswick to Florida and Louisiana, abundant east of Allegheny Mountains.

MAINE.-Fresh ponds (Williamson, 1832); Maine (Holmes, 1862, U. S. N. M., 1880, Goode, 1884, Jordan \& Evermann, 1896, and Kendall, 1904 and 1908); Thompson Pond (Bowdoin College coll., 1900 [1883]); Craig's Pond (Merrill coll., 1898); Pushaw Pond, Toddy Pond and Alamoosook Lake (Merrill coll., 1899); Cobbosseecontee Lake (Kendall 
coll., 1899a, and Smith, 1901); Lake Auburn (Kendall \& Gould coll., 1900): Ambajejus Falls, First and Second Hurd Ponds, Fourth Debsconeag Lake, Pokwokamus Deadwater and Hale Pond (Kendall \& Gould coll., 1901); outlet and inlet of Bowlin Pond (Kendall \& Gould coll., 1902); Green Lake, Branch Pond and Floods Pond (Kendall coll., 1903); "common" (Atkins coll., 1903); Moose and Indian Ponds, and Sebasticook River [?] (Bowman coll., 1904); Floods Pond (Kendall coll., 1904).

89. L e pom is gibbosus (Linnceus.) SUNFish ; "Sunny"; "Flatish"; "Roach"; "Hogback".

Range.-Great Lakes region to New Brunswick and southward east of the Alleghenies to Virginia; rather rare farther south.

MaIne.-Ponds and mill streams (Williamson, 1832); Maine (Holmes, 1862, Jordan \& Evermann, 1896, and Kendall, 1904 and 1908); Grand Lake Stream (U. S. N. M., 1877); Auburn (U. S. N. M., 1883); Boyden Lake, Pennamaquan Lake and River, Dennys River, Leweys Lake, St. Croix River and Magurrowock Stream (Kendall, 1894); Chickawaka Lake (Kendall coll., 1895a); Sebago and Little Sebago Lakes and Songo River (Kendall coll., 1898): Androscoggin River and Lake Auburn (Merrill coll., 1899); Sebago Lake (Smith, 1900); Little Sebago Lake, Pettengill's Pond and Thomas Pond (Kendall coll., 1899); Cobbosseecontee Lake (Kendall coll., 1899a); Little Sebago Lake (Kendall coll., 1900a); Cobbosseecontee Lake (Smith, 1901); "common" (Atkins coll., 1903); Moose and Indian Ponds and Sebasticook River (Bowman coll., 1904).

90. Micropterus d ol $\mathbf{l} \mathbf{m}$ i e u Lacépède. "BLAcK Bass"; Sirall-Mouthed Black Bass.

Range.-From Lake Champlain to Nanitoba and south- 
ward on both sides of the mountains to South Carolina and Arkansas in cool waters.

Maine.-Cochewagan Pond, Cobbosseecontee Pond, Duck Pond, Trip Pond, Gardner's Pond, Gun Point Ice Company's Pond, Hosmer Pond, Keazer's, Cushman and Little Pushaw Ponds, lakes in Newport and Glenburn, Snow and Belgrade Lakes, Lake Maranacook and Pushaw Pond (Page, 1884); Boyden and Pennamaquan Lakes (Kendall, 1894); (hickatwaka Lake (Kendall coll., 189.5a); mouth Songo River, Presumpscot River and Little Sebago Lake (Kendall coll., 1898, 1899, 1900a, 1901, 1902 and 1903); outlet of Thomas Pond, in South Casco, and Cobbosseecontee Lake and inlets (Kendall coll., 1899a); Sebago Lake (Smith, 1900); Gun Point Ice Company's Pond (Kendall \& Gould coll., 1900); Cobbosseeenontee Lake (Smith, 1901); Little Sebago Lake (Kendall coll., 1901a); Wissataquoik Deadwater (Kendall \& Gould coll., 1902); Presumpscot River, Sebago and Little Sebago Lakes, Green Lake and Branch Pond (Kendall coll., 1903 ); "introduced, common" (Atkins coll., 1903); Moose and Indian Ponds (Bowman coll., 1904); Maine (Me. F. C. Report, $1870,1872 a, 1875,1876,1877,1878,1882,1883$, $1886,1888,1896 a$ and 1899 , and Kendall, 1904 and 1908).*

PERCID E. 'The Perches.

91. Perca flavescens (Mitchill). Yellow Perch; "Perch"; "Brindle Perch".

Range.-Abundant in the Great Lakes and in coastwise streams from Nova Scotia to North Carolina; upper Mississippi and St. Lawrence waters.

Matne.-Maine (Williamson, 1832, Storer, 1853 and $1867 \alpha$, Holmes, 1862, and Kendall, 1904 and 1908); Auburn (U. S. N. M., 1883); Thompson's Pond (Bowdoin Col-

"Introduced and now widely distributed in southern half of the state. 
lege coll., 1900 [1883]); Piscataqua River (Atkins, 1887) ; Grand Lake, Grand Lake Stream, Meddybemps Lake, ete. (Kendal1, 1894); Songo and Presumpscot Rivers, Sebago and Little Sebago Lakes (Kendall coll., 1898, 1899 and $1900)$; Pettengill Pond, Panther Pond, Rattlesnake Pond, Thomas Pond, and Cobbosseecontee and Maranacook Lakes (Kendall coll., 1899a); Sebago Lake (Smith, 1900); Cobbosseecontee Lake (Smith, 1901); Thomas Pond (Kendall coll., 1900a); East Branch of Penobseot River and Matagamonsis Lake (Kendall \& Gould coll., 1900); Ambajejus Falls, Hurd Pond, First, Second and Fourth Debsconeag Lakes, Pokwokamus Deadwater, East Branch of Penobscot River below Matagamon dam, and Matagamonsis and Beau Lakes (Kendall \& Gould coll., 1901); Presumpseot River and Thomas Pond (Kendall coll., 1902); Green Lake, Branch Pond and First Debsconeag Lake (Kendall coll., 1903); Wissataquoik Deadwater and Little Sebago Lake (Kendall \& Gould coll., 1902); "common" (Athins coll., 1903); Moose and Indian Ponds, and Sebasticook River (Bowman coll., 1904); St. John River, near Fish River (Evermann, 1905).

SERRANID A. The Sea Basses.

92. Roceus lineatus (Bloch). "STriped Bass"; "SEA BASs".

Range.-Atlantic coast of North America from Gulf of St. Lawrence to Gulf of Mexico.

Matne.-Kenduskeag (Williamson, 1832); Maine (Storer, 1853 and 1867 a, Holmes, 1862, Me. F. C. Report, 1868 and 1869, Me. S. and S. F. Report, 1892, 1897, 1898, 1901, 1903, 1905, 1907, 1909, 1911 and 1913, and Kendall, 1908); Merrymeeting Bay, Saco River, Kennebec River, Eastern River and Sebasticook River (Foster \& Atkins, 1868); Ken- 
nebec, Sebasticook, Sheepscot, Eastern, Dyer, St. Croix and Piscataqua Rivers, Merrymeeting Bay, IVinnegance Creek and Casco Bay (Atkins, 1887); Wolf's Neck (Pettengill coll., 1900 [young]) ; Small Point (Lee, 1885, and Kendall coll., 1896); Eastern River and Verona (Evermann, 1904).

93. Morone americana (Gmelin). "White PERCH"; "SEA Perch"; "SEA BAss".

Range.-Atlanic Coast of United States from Nova Scotia to South Carolina. A permanent resident in some northern lakes and in rivers sonthward.

MAINE.-Salt and fresh water ponds, coves and rivers (IVilliamson, 1832); Maine (Storer, 1853 and $1867 a$, Holmes, 1862 , Me. F. C. Report, $1869,1888,1896 \alpha$ and 1899 , and liendall, 1904 and 1908); lakes emptying into Kennebec River as far back as Skowhegan in Penobscot River, still further north, and in the lakes of the St. Croix and intervening territory (Foster \& Atkins, 1868); Grand Lake Stream (U. S. N. M., 1877) ; Casco Bay (Lee, 1885); Sheepscot River and Middle Bay (Bowdoin College coll., 1900 [1889]); Freeport and Eastport (Kendall coll., 1893); Sysladobsis Jake, Big and Leweys Lakes, and Meddybemps Lake (Kendall, 1894); Grand Lakes (Rathbun \& Wakeham, 1897); Pushaw and Cochnewagan Ponds (Merrill coll., 1899); Sebago Lake (Smith, 1900); Sebago and Little Sebago Lakes (Kiendall coll., 1898, 1899 and $1900 a)$; Cobbosseecontee Lake (Kendall coll., 1899a, and Smith, 1901); Pokwokamus Deadwater (Kendall \& Gould coll., 1901); Wolf's Neck, Freeport (Pettengill coll., 1900); Harraseeket River (Kendall coll., 19016 and 1902, and Smith, 1902); Little Sebago Lake (Kendall coll., 1902); Green Lake and Branch Pond (Kendall coll., 1903); "common" (Atkins coll., 1903); Moose and Indian Ponds, and Sebasticook River (Bowman coll., 1904). 
94. Centropristes striatus (Linnceus). BLACK SEA Bass.

Range.-Maine to Florida.

Maine.-Casco Bay at Small Point (Kendall coll., 1896, and Smith \& Kendall, 1898); Maine (Kendall, 1903 $a$ and 1908); Matinicus Island (B. S. N. H., Arethusa coll., 1880).

95. Stenotomus chrysops (Linnceus). Scup; PORGY.

Range.-Maine to South Carolina.

MaIne.-Maine (Holmes, 1862); Eastport (U. S. N. M., 1872) ; Small Point (Kendall coll., 1896, and Smith \& Kendall, 1898); Maine (Kendall, 1903a).

SCI KNID A. The Croakers.

96. Menticirrbus saxatilis (Bloch achelencer). KingFish; Minkfish.

Range.-Cape Ann to Pensacola.

MAINE._"Seldom seen" (Williamson, 1832); Casco Bay (Lee, 1885, and Bowdoin College coll., 1900 [1880]); Maine (Kendall, 1903 $\alpha$ and 1908).

97. Cynoscion regalis (Bloch \& Schneider). Squeteague; Weakfish; "Trodt".

Range.-Cape Cod to Mobile.

Matne.-Maine (Holmes, 1862).

LABRID E. The WRASSE-FISHes.

98. Tautogolabrus adspersus (Walbaum). "CUNNER".

Range.-Labrador to Sandy Hook.

MAIne.-Casco Bay and eastward (Williamson, 1832); 
('uast of Maine (Perley, 1852): Maine (Storer, 18 46,1855 and $1867 a$, and Holmes, 1862); Portland (Bean, 1881); Casco Bay (U. S. N. M., 1873, Lee, 1885, and Kendall coll., 1892, 1896, 1898 and 1893); Freeport (Kendall coll., 1900 and 1902) ; Orr's Island, Casco Bay (Kendall \& Gould colll., 1900); Penobscot River and Bay (Evermann, 1904).

99. Tautoga onitis (Linnous). 'TautoG; "MonTAUG".**

Range.-New Brunswick to South Carolina.

Maine.-Maine (Perley, 1852, Storer, 1846, 1855 and 1867 a, Holmes, 1862, Jordan \& Evermann, 1896, and Kendall, 1908); Caseo Bay (Lee, 1885); Small Point (Kendall coll., 1896); Orr's Island (Kendall \& Gould coll., 1900); mouth of Harraseeket River, Freeport (Parker coll., 1901 [?]); Porter's Landing Brook, Freeport (Townsend coll., 1903); Penobseot River and Bay (Evermann, 1904); Bustin's Island, Casco Bay (Kendall coll., 1912).

101). Alentera schoepfii (Wulluum). "FiLEFish"; FOOLEISH.

Range.-Cape Cod to Texas.

MAINE.-Portland (Storer, 1845, 1846, 1863 and $1867 a$, and Kendall, 1908).

TETRAODONTID E. The Puffers.

101. Spheroides maculatus (Bloch of Selneider). PufFer ; Swell-ToAd; Blower ; "Balloon-Fish".

Range.-Casco Bay to Florida.

MLine.-Small Point (Kendall coll., 1896, and Smith \& Kendall, 1898); Maine (Ḱendall, 1903a and 1908).

*A corruption of the proper name. 
MOLID E. The Headfishes.

102. Mola mola Linncus. "Sunfish."

Range.-Pelagic in most temperate and tropical seas; north to England, Grand Banks and San Francisco.

MaIne.-Maine (Williamson, 1832); Portland (U. S. N. M., 1875, and Kendall, 1908); Cod Ledge and near Seguin (Willard, 18.95); off Small Point, 1907 (Norton); Cod Ledge (E. D. Rackliff coll., 1911 and 1912).

SCORP ANID A. ThE RockFishes.

103. Sebastes ma rinus (Linncus). "ReDFIsH"; "Red Breani"; "Red Perch"; "Roseeish".

Range.-North Atlantic on both coasts; south, in deep water, to off coast of New Jersey.

Maine.-Near Portland (Perley, 1852); Maine (Storer, 1853 and 1867 , Holmes, 1862, Gill, 1873, Jordan \& Evermann, 1896, and Kendall, 1908); Eastport (B. S. N. H., Saltonstall \& Emerton coll. and Verrill coll., Verrill, 1871, U. S. N. M., 1872, Boardman \& Atkins, 1875, Goode \& Bean, 1895, Bean, 1881, and Kendall coll., 1893); Casco Bay (U. S. N. M., 1873, and Lee, 1885).

COTTID E. The Sculpins.

104. Cottus gracilis (Heckel). BLOB; Fresh W Ater Sculpin; Miller's 'Thumb; "Rock Cusk"; "Brook Cusk".

Range.-Recorded from New Brunswick west to New York.

Maine.-Auburn (U. S. N. M., 1883); Richardson Lake (B. S. N. H., Putnam coll.); Bear River (Bowdoin College coll., 1900 [?] ); Webster, Chamberlain, Eagle, Churchill 
and Beau Lakes, Cross Lake Thoroughfare and tributary of Aroostook River (Kendall \& Gould coll., 1901, and Kendall coll., 1903); Square Lake and Cross Lake Thoroughfare (Kendall coll., 1903); Rangeley Lakes (Atkins coll., 1903b); Sebago Lake (Moses coll., 1906, and Kendall coll., 1907 and 1908); Cold Spring Brook, Gorham (Melville Waterhouse, P. S. N. H. coll.); Maine (Kendall, 1908).

105. Myoxocephalus aenus (Mitehill). Grubву; LitTle SculpiN.

Range-Maine to New York.

Matxe.-Casco Bay (U. S. N. M., 1873, and Lee, 1885); Wolf's Neck (Pettengill coll., 1884 and 1900); Maine (Kendall, 1908).

106. Myoxocephalus scorpius ( Limmen: S). SHoptTHORN SCULPIN.

Range.-Aretic regions and northern Europe.

Marve.-Maine (Holmes, 1862 [?]); Eastport (Goode \& Bean, 1879, Bean, 1881, Kendall, 1908, Kendall coll., 1893, and Jordan \& Evermann, 1898); Caseo Bay at Freeport (Kendall coll., 1892 and 1896).

117. Myoxocephalus groenlandicus (c'ucier t. Valenciennes). "Deep Water SculpiN"; "Black SculPIN".

Range.—Greenland to New York.

MAINe.-Maine (Girard, 1849, Storer, 1846, 1853 and $1867 a$, Holmes, 1862, and Kendall, 1908); Eastport (Verrill, 1871, U. S. N. M., 1872, and Kendall, 1893); Casco Bay (U. S. N. M., 1873); Bucksport (U. S. N. M., 1878); off Caseo Bay and oft Whaleboat Island (Kendall coll., 1892) ; Penobscot River and Bay (Evermann, 1904). 
108. Myoxocephalus octodecemspinosus (Mitchill). "Sculpin."

Range.-Labrador to Virginia.

MAINE.- "Mouths of salt water harbors and rivers" (Williamson, 1832); Maine (Holmes, 1862, and Kendall, 1908); Eastport (Verrill, 1871); Casco Bay (U. S. N. M., 1873); Bucksport (U. S. N. M., 1878); Portland (Bean, 1881); Eastport (Kendall coll., 1893); Casco Bay (Kendall coll., 1892, 1893, 1898 and 1903, and Lee, 1885); Small Point (Kendall coll., 1896); Wolf's Neck, Freeport (Pettengill coll., 1900); Freeport (Kendall coll., 1902 and 1903).

109. Gymnocanthus tricuspis (Reinhardt). NAKEDSPINED SCULPIN.

Range.-South to Norway and Maine.

Maine.-Eastport (U. S. N. M., 1872, and Kendall, 1908).

110. Hemitripterus anericanus (Gm.lin). NE.A RAVEN; "TOADFISH".

Range.-Labrador to New York.

MAIne.-Salt water harbors (Williamson, 1832); Maine (Storer, 1853 and 1867a, Holmes, 1862, and Kiendall, 1908); Eastport (U. S. N. M., 1872); Casco Bay (U. S. N. M., 1873) ; Bucksport (U.S. N. M., 1878) ; Eastport, Portland and Bucksport (Bean, 1881); Casco Bay (Lee, 1885); Eastport (Kendall coll., 1893); Small Point (Kendall coll., 1896).

AgONid A. The Alligator Fishes.

111. Aspidophoroides monopterygius (Bloch). Alligator-Fish.

Range.-Greenland to Cape Cod.

Maine.-Maine (Holmes, 1862, and Kendall, 1908): Eastport (U. S. N. M., 1872, and Kendall coll., 1893). 
CYCLOPTERIDE. The Lumpashes.

112. Cycloptexus lumpus Linncus. "LUMPFISH"; "LUMP-SUCKER"; "LUMP".

Range.-North Atlantic on both coasts south to New Jersey and France.

Maine. - IV esterly coast of the State (Williamson, 1832); Maine (Storer, 1846, 1863 and 1867a, and Kendall, 1908); Eastport (U. S. N. M., 1872, and Kendall coll., 1893); Bucksport (U. S. N. M., 1878); off Seguin (B. S. N. H., Arethusa coll., 1880); Casco Bay (U. S. N. M., 1873 and 1887, and Lee, 1885); 'Bay of Fundy (Bowdoin College coll., 1900 [1891]); off the coast (Kendall coll., 1895b, and Kendall coll., 1896); Small Point, Casco Bay (Kendall coll., 1896); Penobscot River and Bay (Evermann, 1904); Sturdevant's Island (Kendall coll., 1909).

11:). Eumicrotremus spinosus (Muller). Nixy LUMPFISH.

Range.-North Atlantic and Arctic Oceans, south to Maine and Denmark.

MAINE.-Eastport (Garman, 1892, Jordan \& Evermann, 1898, and Kendall, 1908.)

LIPARIDIDA. THE SEA SNAILS.

114. Neoliparis atlanticus Jordan \& Evermann. Sea-snall; Dusiky SeA-SLUg.

Range.-Newfoundland to Cape Cod.

Marne.-Portland Harbor (Storer, 1867 and 1867a); Eastport and Portland Harbor (Garman, 1892); near Kittery (Bowdoin College coll., 1900 [?]); Seguin Island (Spinney coll., 1900); rocky shores of Cape Elizabeth in winter; Maine (Kendall, 1908). 
115. Liparis liparis (Cuvier). Striped Sea Slug; Striped SEA-SNAIL.

Range.-North Atlantic on both coasts north to Spitsbergen, south to Connecticut and France.

MaInE.-Y Yellow Rock (Kendall coll., 1893); Maine (Garman, 1892, Jordan \& Evermann, 1898, and Kendall, 1908).

BATRACHOIDIDA. The ToAdFishes.

116. Opsanus tau (Linncus). ToAdFish.

Range.-Cape Cod to Cuba.

MAINE.-Maine (Storer, 1846, 1855 and 1876a, and Kendall, 1908); Kittery (Holmes, 1862).

ECHENEIDID E. The Remoras.

117. Echeneis naucrates (Linnceus). Sharisucker; Pega; Pegador; Sucking-fish.

Range.-Warm seas, universally distributed; common north to Cape Cod, and occasionally to San Francisco.

Marne.-Seal Harbor, Knox County (Bowdoin College coll., 1907).

Xiphididid. 'The Gunnels.

118. Pholis gumnellus (Linneus). Gunnel; "ROCK-EEL".

Range.-North Atlantic, Labrador to Wood's Hole, Mass., and Norway to France.

MaINe.-Maine (Storer, 1855 and $1867 \alpha$, Holmes, 1862, and Kendall, 1908) ; Eastport (U.S. N. M., 1872, Bean, 1881, and Kendall coll., 1893); Caseo Bay (U. S. N. M., 1873, Lee, 1885, and Kendall coll., 1892); New Meadows River (Bowdoin College coll., 1900 [1890]); Saco Bay, Muscongus Bay, and Matinicus Rock (Norton). 
STICHAIDA. THE SHANNIES.

119. Ulvaria subbifurcata (Storer). RADIATED SHANNY; "LITTLE-CUSK".

Range.-North Atlantic, south to Cape Cod.

MaInE.-Maine (Holmes, 1862, Gill, 1873, and Kendall, 1908); Casco Bay (U. S. N. M., 1873); Matinicus Rock (Norton coll., 1903).

120. Leptoclinus maculatus (Fries). Shanns.

Range.-Arctic seas and south to Gulf of Maine, Aleutian Islands, Norway and Sweden.

MAINE.-Gulf of Maine (U.S. N. M., 1877a).

121. Lu mpen u lumpetraeformis (Wulbum). SERPENT BLENNY.

Range.-North Atlantic and Arctic, on both coists south to Siveden and Norway, and south to Cape Cod.

MAINE.-Eastport (U.S. N. M., 1872, and Kendall, 1908).

CRYPTACAN'THODIDE. THE WRYMOUTHS.

122. Cryptacanthodes maculatus (Storer"). WRYMOUTH ; "CONGER EEL"; "BASTARD-CUSK"。

Range.-Labrador to Long Island Sound.

Matne.-Piscataqua River (Peck, 1804); Maine (Williamson, 1832, Holmes, 1862, Gill, 1873, and Kendall, 1908); Eastport (U. S. N. M., 1853); Eastport (Kendall coll., 1893); Casco Bay (Kendall coll., 1878, Lee, 1885, and Bowdoin College coll., 1900 [1880]); Middle Bay (Bowdoin College coll., 1900 [1897] [white]).

ANARHICHADIDE. THE WOLEFISHES.

123. Anarhichas Iupus (Limneus). IVOLFFISH; "CATFISH". 
Range.-North Atlantic on both coasts south to Cape Cod and France.

Marne.-Maine (Williamson, 1832, Storer, 1846, 1855 and $1867 a$, Holmes, 1862, and Kendall, 1908); Eastport, Me. [and Grand Manan, N. B.] (Verrill, 1871 and 1872); Casco Bay (Kendall coll., 1878, and Lee, 1885); Eastport (Kiendall coll., 1893); White Head Ind and adjacent waters (Norton).

124. Anarhichas minor Olafsen. SPOTted WolfFISH.

Range.-North Atlantic on both coasts, chiefly north of Aretic Circle, south to Gloucester, Mass., and Norway.

Maine.-Eastport (Goode \& Bean, 1880 and 1896, and Jordan \& Evermann, 1898a).

ZOARCIDA. The Eelpouts.

125. Zoarces anguillaris (Peck). "EelpouT"; "Conger Eiel"; "MIother-of-Eels"; "Lipsyish"; LaMPER-EEL”.

Range.-Labrador to Delaware.

MALne.-Piscataqua River (Peck, 1804); Eastern River (Williamson, 1832); Maine (Storer, 1846, 1855 and $1867 \alpha$, Holmes, 1862, Gill, 1873, and Kiendall, 1908); Eastport (B. S. N. H., Hyatt \& Vanbleck coll., U. S. N. M., 1872, and Kendall coll., 1893); Bucksport (U. S. N. M., 1878); Casco Bay (Lee, 1885); Eastport and Portland (Bean, 1881); Small Point (Kendall coll., 1896); off Whaleboat and Eagle Islands (Kendall coll., 1903 and 1904).

126. Lycenchelys verrillii (Goode \& Bean). WolfEEL.

Range.-Coast of Massachusetts in deep water northward. 
MAine-Gulf of Maine (Goode \& Bean, 1879); coast of Massachusetts northward (Jordan \& Evermann, 1898a).

'TRIGLID A. The SEA-Robins.

127. Prionotus carolinus Linncus. SEA-Robin; (iREENEYE.

Renge.-Maine to South Carolina.

Maine.-Caseo Bay (Bowdoin College coll., 1880, and Lee, 1885); Harpswell (Lee, 1880, and Smith \& Kendall, 1898); off Monhegan (Captain Benner coll., 1882 or 1883); Five Islands (Bowdoin College coll., 1900 [1895]); Small Point (Kendall coll., 1896, and Smith \& Kendall, 1898); Maine (Kiendall, 1903 $\alpha$ and 1908); Mt. Desert (Fred Rackliff in coll. P. S. N. H., 1911); Saco Bay (E. B. Pillsbury coll.).

CEPHALACANTHide. The Fling-Fishes.

128. Cephalacanthus volitans (Linnous). "IFYing-Romin".

Renge.-Atlantic Ocean on both coasts.

Mañe.-Maine (Holmes, 1862, and Kendall, 1908).

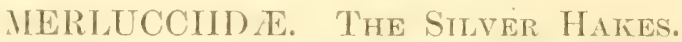

129. Merlucei us bilinearis (Mitchill). SILver Hake; "New Exgland Hake"; "England Hake"; "Whiting"; "Dingy. Hake"; "Dingt".

Range.-Straight Belle Isle to Bahamas.

MAne.-Maine (Holmes, 1862, Gill, 1873, and Kendall, 1908) ; Eastport (U.S. N. M., 1872); Bluehill Bay, Brooklin and Kennebec River (Boardman \& Atkins, 1875); Portland and Eastport (Bean, 1881); Eastport (Kendall coll., 1893); off the coast (Kendall coll., 1895); Small Point, Casco Bay (U. S. N. M., 1872, and Kendall coll., 1896 and 1903); Pas- 
samaquoddy Bay (Moore, 1897); Freeport (Kendall coll., 1898 [young]); Wolf's Neck, Freeport (Pettengill coll., 1900 -[young]); Freeport (Kendall coll., 1902 [young]); Penobscot River and Bay (Evermann, 1904).

GADID E. The Codfishes.

130. Poliachius virens (Linnceus). "Pollack."

Range.-North Atlantic on both coasts south to Block Island and France.

MAINe.- "Bays of Passamaquoddy and the Isle of Holt" (Williamson, 1832); Passamaquoddy Bay (Perley, 1852); Maine (Storer, $1 \times 58$ and $1867 a$, Holmes, 1862 , and Kiendall, 1908); Eastport (Verrill, 1871 and 1872, and U. S. N. M., 1872); on our coast (Boardman \& A tkins, 1875); Hancock County (Wasson, 1878); grounds off Eastport (Bean, 1881, Kendall eoll., 1893, and Kiendall, 1897e); Moosabee Light, off Isle au Haute, off Matinieus Island, off Metinic Island, Monhegan Island, north, northeast, southeast, southwest and west of Monhegan Island, off Seguin Island, and off Cape P'orpoise (Collins \& Rathbun, 1887); Small P'oint (Kendall coll., 1896); Passamaquoddy Bay (Rathbun \& Wakeham, 1897); Cross Island (Moore, 1897); Sheepscot River (Bowdoin College coll., 1900 [?] ); Casco Bay (Lee, 1885, and Kendall coll., 1892, 1903 and 1904); Lumbo Ledge (Kendall \& Gould coll., 1900); Wolf's Neck, Freeport (Pettengill coll., 1900); Freeport (Kendall coll., 1902); Searsport, Stockton Springs and Brooksville (Evermann, 1904).

131. Microgadus tomcod (Wullunem). "Tомсор"; "ToMmycoD"; "Hrosteish".

Range.-Labrador to Virginia.

MAINE.-Narraguagus and Pleasant River (Williamson, 1832); St. Georges River (Eaton, 1851); Maine (Storer, 
1846, 1858 and $1867 a$, Holmes, 1862, Me. S. and S. F. Report, 1897, 1905 and 1907, and Kiendall, 1908); Eastport (U.S. N. M., 1872, and Kendall coll., 1893); Hancock County (Wasson, 1878); Casco Bay (Lee, 1885); Bucksport (U. S. N. M., 1878); Eastport and Portland (Bean, 1881); Machias, Chandler's, Wescongus, Tunk, Penobscot, Kennebec and Piscataqua Rivers, and Casco Bay and tributaries (Atkins, 1887); Wolf's Neck, Freeport (Pettengill coll., 1900); Freeport and Lower Penobscot River (Kendall coll., 1902); P'enobscot River and Bay (Evermann, 1904).

132. Gadus callarias (Linnceus). "CoD"; "CoDFISH"; "Rock COD".

Range.-North Atlantic, south to Virginia and France.

MAINE._-"Marsh Bay" [Penobseot] (Williamson, 1832); Maine (Storer, $1846,18.88$ and $1867 \%$, Holmes, 1862 , Goode, 1875, and Kendall, 1908); Eastport (Verrill, 1871, and U. S. N. M., 1872); Casco Bay (U. S. N. M., 1873, and Lee, 1885); Hancock County (Wasson, 1878); grounds off Moosabec Light, off Petit Manan, off Mount Desert Island, off Isle au Haute, off Matinicus Island, off Metinic Island, Monhegan Island, north, northeast, south and southeast of Monhegan, between Monhegan and Pemaquid, off Seguin Island, off Casco Bay and off Cape Porpoise (Collins \& Rathbun, 1887); St. Croix River (Atkins, 1887); off Whaleboat, Goose and Eagle Islands (Kendall coll., 1892); Eastport and Portland markets (Kendall coll., 1893); Cod Ledge, ete. (Willard, 1895); off the coast (Kendall coll., 1895b); Small Point (Kendall coll., 1896); Eastport (Kendall, 1897a); Passamaquoddy Bay (Rathbun \& Wakeham, 1897); Cross Island (Moore, 1897); Lumbo Ledge (Kíendall \& Gould coll., 1900); Penobseot River and Bay (Evermann, 1904); off Whaleboat and Eagle Islands (Kendall coll., 1903 and 1904). 
13:). M e I a $n$ og a $\mathbf{m} \mathrm{m}$ us aeglifinus (Limners). "HADDOCK"; "WHITE EYE".

Range.-North Atlantic, both coasts south to France and North Carolina.

MAINE.-Shores as far eastward as Mount Desert (Williamson, 1832); between Campobello and Eastport (Perley, 1852 ) ; Maine (Storer, $18 \$ 6,1858$ and $1867 a$, Holmes, 1862 , and Kendall, 1908); Eastport (Verrill, 1871 and 1872, U. S. N. M., 1872, Kendall coll., 1893, and Kendall, 1897 $a$ ); Casco Bay (U. S. N. M., 1873, and Lee, 1885); grounds off Petit Manan, off Mount Desert Island, off Isle au Haute, off Matinicus Island, off Metinic Island, Monhegan, southeast and west of Monhegan, between Monhegan and Pemaquid, off Sieguin Island, off Casco Bay, and off Cape Porpoise (Collins \& Rathbun, 1887); Passamaquoddy Bay (Rathbun \& Wakeham, 1897); Cross Island (Moore, 1897); Casco Bay (Kendall coll., 1898, 1903 and 1904); Small Point (Kendall coll., 1896); Lumbo Ledge, Casco Bay (Kendall \& Gould coll., 1900) IVhite Head Nud and Cod Ledge (fide, Norton).

134. Lota maculosa (Le Sueur). Burbot; Fresh Water Cusk; "CusK"; "Que D'ANGUILLE".

Range.-New England and Great Lakes region north to the Arctic Seas and west to the head waters of the Missouri, the Frazer River basin, and Behring Strait.

MaIne.-Sebago Lake (Mitchill, 1818); Moosehead Lake (Williamson, 1832); Eagle and St. Francis Lakes (Perley, 1852); Maine (Holmes, 1862, Putnam \& Pickering, 1865, and Kendall, 1904 and 1908); Sebago Lake (Bowdoin College coll., 1900 [?]); Stillwater River (Merrill coll., 1899); Sebago Lake (Smith, 1900); Matagamon Lake (Kendall \& Gould coll., 1900); Hurd Pond, and Round and Beau Lakes 
(Kendall \& Gould coll., 1901); Sebago Lake, Green Lake and Cross Lake Thoroughfare (Kendall coll., 1903); “common north" (Atkins coll., 1903); Eagle Lakes (Evermann, 1905); Moose Pond and Sebasticook River (Bowman coll., 1904).

135. Urophycis regius (Walbaum). SPотted HaкE.

Range.-Cape Cod to the Carolinas.

MAINE:-Off Seguin Island (B. S. N. H., Arethusa coll., 1880, and Kendall, 1908).

136. Urophycis tenuis (Mitchill). "HAKE"; WHITE-HAKE.

Range.- Banks of Newfoundland to Cape Hatteras.

MAINE. - Within three leagues of Castine (Williamson, 1832); Maine (Storer, 1859 and 1867 a, Holmes, 1862, Gill, 1873, and Kendall, 1908); Eastport (Verrill, 1871, U. S. N. 1I., 1872, Bean, 1881, Kendall coll., 1893, and Kendall, $1897 a$ ): Casco Bay (U. S. N. M., 1873, and Lee, 1885); Hancock County (Wasson, 1878); Passamaquoddy Bay (Rathbun \& Wakeham, 1897); Cross Island (Moore, 1897); Grounds off Moosabec Light, off Petit Manan, off Isle au Hatute, off Matinicus Island, off Metinic Island, southeast of Monhegan, between Monhegan Island and Pemaquid, and off Seguin Island (Collins \& Rathbin, 1887); off the coast (Kendall coll., 18956); Small Point (Kiendall coll., 1896); Bay of Fundy (Bowdoin College coll., 1900 [1891]); IVolf's Neck (Pettengill coll., 1900); Casco Bay (Kendall coll., 1903).

137. U roph y e is chuss (Walbaum). "SQUIRRELHAKE."

Range.-Gulf of St. Lawrence to Virginia.

MaIne.-Maine (Holmes, 1862, and Kendall, 1908); Hanrock County (Wasson, 1878); Eastport (Kenclall coll., 1903); 
off the coast (Kendall coll., 1895); Passamaquoddy Bay (Rathbun \& Wakeham, 1897); Small Point, Casco Bay (Kendall coll., 1896); Freeport (Kendall coll., 1898 and 1902 [young]); Wolf's Neck, Freeport (Pettengill coll., $1900)$.

138. Enchelyopus cimbrius (Linnceus). FourBEALDED ROCKLING.

Range.-North Atlantic on both coasts south to New York, and Norway and Siveden.

MaIne.-Jonesport (Kendall coll., 1893); off Pemaquid (B. S. N. H., Arethusa coll., 1880); Maine (Kendall, 1908).

\section{Brosmius brosme (Muller). "Cusk."}

Range.-North Atlantic south to Cape Cod and Denmark.

Ma1ne.-Maine (Williamson, 1832, Holmes, 1862, and Kendall, 1908); Casco Bay (Lee, 1885); grounds off Matinicus Island, Monhegan Island, southeast of Monhegan and off Cape Porpoise (Collins \& Rathbun, 1887); off Wells Bay and Cape Porpoise (Atwood, 1867); Cod Ledge, 1912 and 1913 (fide, Norton); Eastport (Kendall coll., 1893).

MACRURIDA. The Grenadiers.

140. Macrourus bairdi (Goode \& Bean). GrenaDIER; RAT-TAIL.

Range.-West Indies to Maine, in deep water.

Maine.-Eastport (Kendall coll., 1893); Maine (Kendall, $1902 b$ and 1908). 
PLEURONECTIDE. THE FlatT-Fishes.

141. H ippoglossus hippoglossus Linncens. "HALIBUT."

Range.-All northern seas south to France, Sandy Hook and off San Francisco.

MAINE.-About bays and islands (Williamson, 1832) Maine (Perley, 1852, Storer, 1859 and $1867 \alpha$, Holmes, 1862, and Kendall, 1908); Eastport (U.S. N. M., 1872); off the coast (Kendall coll., 1895); sixty miles southeast of Portland (Perley, 1852); Monhegan (Kendall coll., 1913); Metinic (fide, Norton).

14... Hippoglossoides platessoides (Fulvicius). SAND-DAB.

Range.-North Atlantic, both sides, south to Cape Cod, and the coasts of England and Scandinavia.

MAINE.--Southeastward of Boone Island in twenty-five fathoms, southward of Cape Porpoise in thirty fathoms, off half-way rock in thirty fathoms, off Seguin in twenty-five fathoms, and southward of Monhegan in sixty fathoms (Bigelow, 1914).

143. Paralichthys dentatus Linneus. Sumer FLounder ; "TURBot".

Range.-Maine to Chesapeake Bay.

MAINE.-Maine (Holmes, 1862, and Kendall, 1908); Casco Bay (U. S. N. M., 1873).

144. Lophopsetta maculata Mitchill. "PLAICE"; "SAND-DAI".

Remeje.-Nova Scotia to South Carolina.

Marne.-Casco Bay (U. S. N. M., 1873, and Jordan \& Evermann, 1898a); Eastport (U.S. N. M., 1875); Portland 
(U. S. N. M., 1873, and Bean, 1881) ; Bucksport and Passamaquoddy Bay (Goode, 1881); Fréeport and Small Point (Kendall coll., 1896, and Smith \& Kenditl, 1898); Maine (Kendall, 1903a and 1908).

145. Limanda ferruginea (Storer). "SAND-DAB"; "FlUKE"; "YeLLOW-TAIL".

Range.-Labrador to New York.

Maine.-Maine (Williamson, 1832, Gill, 1873, and Kiendall, 1908); Casco Bay (U. S. N. M., 1873); Gulf of Maine (U. S. N. M., 1877a); White Head Mud (fide, Norton).

146. Pseudopleuronectes a merice a nus ( Walbaum). Winter Flounder; "Flounder"; "Roughback FLOUNDER"; "BLACKBACK".

Range.--Labrador to South Carolina.

MAINe.-Coves and rivers (Williamson, 1832); Maine (Holmes, 1862, Me. S. and S. F. Report, 1898, 1901, 1905 and 1907, and Kendall, 1908); Eastport (U. S. N. M., 1872); Bucksport (U.S. N. M., and Bean, 1879); Hancock County (Wasson, 1878); Casco Bay (Lee, 1885, and Kendall coll., 1892); Casco Bay and Eastport (Kendall coll., 1893); Small Point (Kendall coll., 1896); Wolf's Neck (Pettengill coll., 1900): Freeport (Kendall coll., 1900 and 1902); Lower Penobscot River (Kendall coll., 1902); Penobscot River and Bay (Evermann, 1904).

147. Liopsetta putnami (Gill). "Sлготн FlounDeR"; Smoothback Flounder.

Range.-Cape Cod to Labrador.

Maine.--Coves and rivers (Williamson, 1832); Maine (Gill, 1873, and Kendall, 1908); Caseo Bay (U. S. N. M., 
1873): Portland and Bucksport (U. S. N. M., and Bean, 1879 and 1881); Belfast (Jordan \& Evermann, 1898 $九$ ); Freeport River and Casco Bay (Kendall coll., 1892, 1898, 1899 and 1900); Wolf's Neck, Freeport (Pettengill coll., 1900); Penobscot River and Bay (Evermann, 1904).

14ฬ. Glyptocephalus cynogiossus (limurus). Fluke; Craig Fluke; "Sole".

Range.-Northern seas in deep water.

MAIne.-Maine (Gill, 1873); Eastport (Goode \& Bean, 1896, and Kendall, 1908).

\section{LOPHIIDA. 'T'HE Anglers.}

149. Lophius piscatorius Limneus. "MoNK-FISH"

Range.-North Atlantic, both coasts, south to Cape Hatteras and Barbadoes.

MAINE.-Owl's Head and other bays (Williamson, 1832); Maine (Storer, 1846, 1855 and $1867 a$, Holmes, 1862, Gill, 1873, and Kendall, 1908); Eastport (U. S. N. M., 1872, and Kendall coll., 1893); Casco Bay (Lee, 1885); Small Point (Kendall coll., 1896); Wolf's Neck, Freeport (Pettengill coll., 1900); White Head Mud and Saco lbay (fide, Norton).**

*Explanations of abbreviations and methods of citation of records are given at pages 5 and 6 of this catalogue. Other abbreviations used are P. S. N. H., meaning Portland Society of Natural History, B, S. N. H. meaning Boston Society of Natural History, Me. S. and S. F. Reports, meaning Maine Sea and Shore Fisheries Reports. Throughout the catalogue dates included in the citations of records refer to the bibliography and records which close the paper, thus referring the reader to original authorities. During the progress of printing a few authentic records have been added. where the fixing of dates have been impossible; these appear only under the species affected by them and are not referred to in the list of records. 


\section{ADDENDA.}

COT'IIDA.

Artediellus atlanticus. Jordan \& Evermann.

Range.-Known from Massachusetts Bay.

Maine.-Off Casco Bay in forty fathoms and off Monhegan in sixty fathoms (Bigelow, 1914).

For additional stations of Raia erinacea, Osmerus mordax, Gasterosteus aculeatus, Siphostoma fuscum, I'autogolabrus adspersus, Cyclopterus humpus, Lycenchelys verrillii, Zoarces anguillaris, Ulvaria subbifurcata, Myoxocephalus octodecemspinosus, Hemitripterus americanus, Sebastes marinus, Aspidophoroides monopterygius, Merluccius bilinearis Melanogrammus aglifinus, Gadus callarias, Urophycis regius, Urophycis chuss, Enchelyopus cimbrius, Pseudopleuronectes americanus, Limanda forruginea, Glyptocephalus cynoglossus, Lophins piscatorius, see Bigelow, 1914. 


\section{GEOGRAPHICAL DISTRIBUTION OF THE FRESH- WATER FISHES IN MAINE.}

Peculiarities of the Natural Distribution of the Species of Fresh-water Fishes of Maine.

In a study of the problem of geographical distribution of the species of fishes occurring in Maine, more than the State should be taken into consideration.

The probable eastern limit of most of the species of freshwater fishes occurring in Maine is the sea bounding New Brunswick and Nova Sicotia. How closely related this region is to the St. Lawrence is not definitely known, and how much farther north some of them extend cannot be known until the region north of the St. Lavrence is studied. The Appalachian Mountains on the west form a more or less definite line of demarkation. There are some species immediately west of these mountains that are not found east of them, and a very few east have not been recorded from the west side. There are also some very wide gaps in the distribution of some species which future investigation may more or less completely fill, and there are some of very extensive distribution as well as some apparently more or less isolated occuriences.

In general it may be said that the characteristic fishes are boreal, but the State is to some extent in a transition area, where northern and southern forms more or less overlap; yet not wholly in it but at one end as it were.

From the accompanying table, it may be seen that the majority of Maine species have a wide range of distribution. 
Of the 39 species that may be considered purely fresh water, there are 26 recorded as occurring in the Great Lakes and inflowing streams; 24 in the St. Lawrence River and its tributaries, not counting some closely related if not identical species; 17 that are found further south in the eastern Appalachian slope drainage, even as far soutlr as Florida. There are also 30 species recorded as common to New Brunswick and Maine. 
COMPARATIVE TABLE OF RECORDS OF DISTRIBUTION SHOWING THE SPECIES COMMON TO THE GREAT LAKES, VERMONT, ST. LAWRENCE RIVER BASIN, SOME OF THE STATES OF SOUTH ATLANTIC SLOPE, AND NEW BRUNSWICK.

Matne Fresh-water Fishes.

\begin{tabular}{|c|c|c|c|c|}
\hline $\begin{array}{l}\text { Great } \\
\text { Lakes. }\end{array}$ & $\begin{array}{l}\text { Atlan- } \\
\text { tic } \\
\text { Slope. }\end{array}$ & $\begin{array}{l}\text { St.Law- } \\
\text { rence } \\
\text { River } \\
\text { Basin. }\end{array}$ & $\begin{array}{l}\text { Ver- } \\
\text { mont. }\end{array}$ & $\begin{array}{c}\text { New } \\
\text { Bruns } \\
\text { wick. }\end{array}$ \\
\hline $\mathrm{x}$ & $\mathrm{x}$ & $\mathrm{x}$ & $\mathrm{x}$ & $\mathrm{x}$ \\
\hline $\mathrm{x}$ & $\mathbf{x}$ & $\mathrm{x}$ & $\mathrm{x}$ & $\mathrm{x}$ ? \\
\hline $\mathrm{x}$ & & $\mathbf{x}$ & $x$ & $\mathrm{x}$ \\
\hline $\mathrm{x}$ & $\mathrm{x}$ & $x$ & $\mathrm{x}$ & $\begin{array}{l}\mathbf{x} \\
?\end{array}$ \\
\hline $\mathrm{x}$ & & $x$ & & $\mathrm{x}$ \\
\hline $\mathbf{x}$ & $x$ & $\mathrm{x}$ & $x$ & $\mathbf{x}$ \\
\hline$x$ & $x$ & $x$ & $\mathrm{x}$ & $\begin{array}{l}\mathrm{x} ? \\
\mathrm{x} ?\end{array}$ \\
\hline$x$ & & & & $\mathrm{x}$ \\
\hline \multirow[t]{2}{*}{$\mathrm{x}$} & $\mathbf{x}$ & $\mathrm{x}$ & $\mathrm{x}$ & $\mathrm{x}$ \\
\hline & $\mathbf{x}$ & & & \\
\hline $\mathrm{x}$ & $x$ & $\mathrm{x}$ & $x$ & $\mathbf{x}$ \\
\hline$x$ & $\mathrm{X}$ & $x$ & $x$ & $x$ \\
\hline$x$ & & $\mathrm{x}$ & $x$ & $x$ \\
\hline $\mathbf{x}$ & $\mathrm{x}$ & $x$ & $x$ & $x$ \\
\hline$x$ & & $x$ & $\mathbf{x}$ & $x$ \\
\hline \multirow[t]{3}{*}{$\mathrm{x}$} & & $\mathrm{x}$ & $x$ & $\mathrm{x}$ \\
\hline & & : & & ? \\
\hline & & $\dagger$ & & $x$ \\
\hline $\mathrm{x}$ & & $\mathrm{x}$ & $\mathrm{x}$ & $x$ \\
\hline \multirow[t]{3}{*}{$x$} & $\mathrm{x}$ & $x$. & $x$ & $\mathbf{x}$ \\
\hline & & $\dagger$ & & \\
\hline & & $\mathrm{x}$ & $x$ & $x$ \\
\hline$x$ & & $\mathrm{x}$ & & $\mathrm{x}$ \\
\hline $\mathrm{x}$ & $x$ & $x$ & $x$ & $x$ \\
\hline $\mathrm{x}$ & & $\mathrm{x}$ & $x$ & $\mathrm{x}$ \\
\hline \multirow[t]{2}{*}{$x$} & $x$ & & & $x$ \\
\hline & & & & $\mathrm{x}$ \\
\hline$x$ & $\mathbf{x}$ & & & $\mathrm{x}:$ \\
\hline$x$ & $x$ & $x$ & $x$ & $\mathrm{x}$ \\
\hline \multirow[t]{2}{*}{$\mathrm{x}$} & $x$ & $x$ & $\mathrm{x}$ & $x$ \\
\hline & $\mathrm{x}$ & & & $x$ \\
\hline $\mathbf{x}$ & & $\mathbf{x}$ & $\mathrm{x}$ & $x$ \\
\hline$x$ & & $x$ & $x$ & $x$ \\
\hline
\end{tabular}

1. Ameiurus nebulosus

2. Erimyzon oblongus

i). Catostomus catostomus

4. Catostomus commersonii

5. Pimephales anuli

6. Chrosomus erythrogaster

7. Semotilus bullaris

8. Semotilus atromaculatus

9. Leuciscus carletoni

10. Phoxinus neogieus

11. Abramis erysoleucas

12. Notropis kendalli

13. Notropis bifrenatus

14. Notropis cornutus

15. Rhinichthys atronasus

16. Conesius plumbeus

17. Anguilla rostrata

18. Coregonus quadrilateralis

19. Coregonus labradoricus

20. Coregonus stanleyi

21. Salmo sebago

22. Salvelinus namaycush

23. Salvelinus fontinalis

24. Salvelinus oquassa

25. Salvelinus aureolus

26. Osmerus mordax

27. Osmerus abbottii

28 . Osmerus spectrum

29. Fundulus diaphanus

30. Esox reticulatus

31. Eucalia inconstans

32. Pungitius pungitius

38. Grasterosteus atkinsi

34. Lepomis auritus

35. Lepomis gibbosus

36. Perca tlavescens

:3. Morone americana

38. Cottus gracilis

39. Lota maculosa

"This snecies occurs in Chateaugay Lake in New York, in St. Lawrence River Basin. $\div$ A closely related species occurs in some waters in Quebec. 


\section{RECORDED NATURAL DISTRIBUTION OF NATIVE FRESH- \\ WATER FISHES OF MAINE BI PRINCIPAL RIVER BASINS EXAMINED BI THE BUREAU \\ OF FISHERIES.}

St. Jobn.

MaINe Fresh-Water Fishes.

1. Ameiurus nebulosus

2. Erimyzon oblongus

3. Catostomus catostomus

4. Catostomus commersonii

5. Pimephales anuli

6. Chrosomus erythrogaster

7. Semotilus bullaris

8. Semotilus atromaculatus

9. Lenciscus carletoni

10. Phoxinus neogrus

11. Abramis crysoleucas

12. Notropis bitrenatus

13. Notropis kendalli

14. Notropis cornutus

15. Rhinichthys atronasus

16. Couesius plumbeus

17. Anguilla rostrata

18. Coregonus quadrilateralis

19. Coregonus labradoricus

20. Coregonus stanleyi

21. Salmo sebago

22. Salvelinus namaycush

23. Salvelinus fontinalis

24. Salvelinus oquassa

25. Salvelinus aureolus

26. Osmerus mordax

27. Osmerus spectrum

28. Osmerus abbottii

29. Fundulus diaphanus

30. Esox reticulatus

31. Eucalia inconstans

32. Pungitius pungitius

33. Gasterosteus atkinsii

34. Lepomis auritus

35. Lepomis gibbosus

36. Micropterus dolomieu*

37. Perca flavescens

38. Morone americana

39. Cottus gracilis

40. Lota maculosa

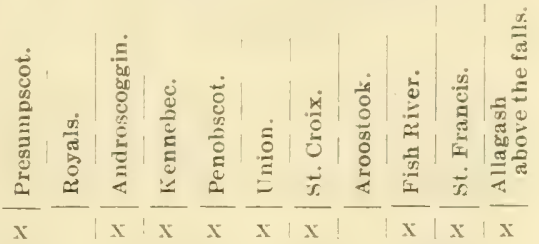

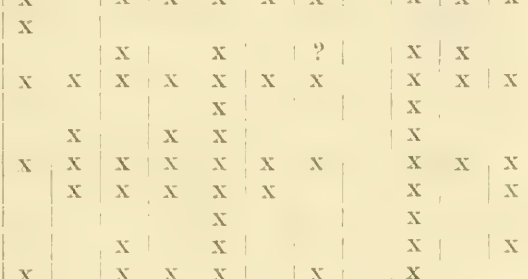

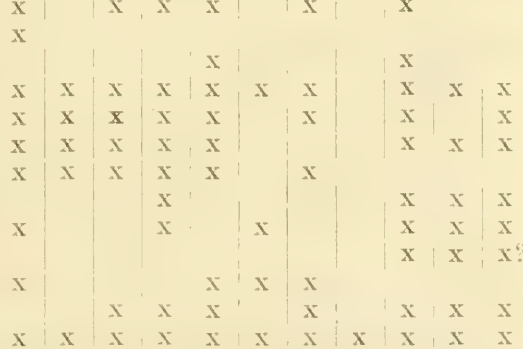

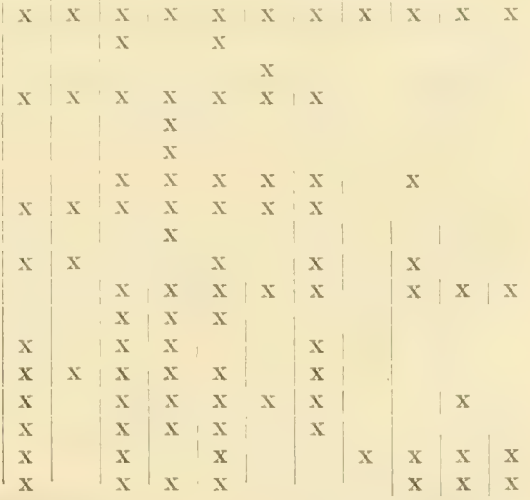

*The black bass has become so well established and so widespread that it is here considered to be a Maine fish. 


\section{ALPHABETICAL LIST AND DEFINITIONS OF THE LOCALITIES FROM WHICH FISHES ARE RECORDED IN THIS CATALOGUE.}

Alamoosook Lake.-Tributary Penobscot River, Hancock County, Orland; through Orland, Eastern or Narramisic River.

Allagash River.-Tributary St. John River, rising in Chamberlain Lake, flowing north, including a series of large lakes in its course.

Allagash River Lakes._Chamberlain, Eagle, Churchill, Umsaskis, Long and Round Lakes.

Ambajejus Falls.-Just above Ambajejus Lake, West Branch Penobscot River.

Androscoggin River.-Rises in Umbagog Lake, one of the Rangeley Lakes, flowing through New Hampshire and western Maine, joining Kennebec waters at Merrymeeting Bay, Sagadahoc County.

Aroostook River.- - Tributary St. John, flowing east through Aroostook County, joining St. John in New Brunswick.

Auburn.-On Androseoggin River, Androseoggin County.

Auburn Lake.-Tributary Androscoggin, Androscoggin County, Auburn.

Bayaduce River.-An arm of Penobseot Bay, east of Castine, in Hancock County, the head in Sedgwick.

Bald Head.-A rocky headland, Phippsburg, one mile west of Small Point.

Bangor.-Penobscot County, on Penobscot River. Head of marine navigation. 
Bay of Fundy.-Large bay between eastern Maine and New Brunswick and Nova Scotia.

Bear Brook.-Tributary Long Lake, Cumberland County, Harrison.

Bear River.-Tributary Androscoggin River, Oxford County, Newry.

Beau Lake.-Expansion of St. Francis River, between Maine and New Brunswick, northern Aroostook County.

Belfast.--On west side of Penobscot Bay, Waldo County.

Belfast Bay.-At east side of Penobseot Bay, Belfast, Waldo County.

Belgrade._On Belgrade Lakes, Kennebec County.

Biddeford Pool.-An inlet of sea in Biddeford, York County, below the mouth of Saco River; Fletcher's Neck forms the south and east barriers.

Big Lake.-One of the western St. Croix chain, receiving waters of Grand Lake through Grand Lake Stream, Washington County.

Bill Fish Brook.-Small tributary East Branch of Penobscot River about one mile below Matagamon Lake.

Birch Brook._Tributary Cross Lake, A roostook County.

Bluehill.-On east side of Bluehill Bay, Hancock County.

Bhehill Bay.-West of Mt. Desert, and east of Bluehill, Brooklin and north of Swan's Island, Hancock County.

Boone Island.-Off York County.

Boothbay.-Town and bay of same name near mouth of Kennebec River, or between the mouths of Sheepscot and Damariscotta Rivers, Lincoln County.

Bowlin Brook.-Outlet Bowlin Pond.

Bowlin Pond.-Tributary East Branch Penobscot River Penobscot County. 
Boyden Lake.-Flows into Passamaquoddy Bay, IVashington County.

Bradley.-East side Penobscot River, eleven miles northeast of Bangor, Penobscot County.

Branch Pond.--Tributary Union River, Hancock County, Ellsworth.

Bristol.-Between mouth of Damariscotta River and Muscongus Bay, Lincoln County.

Brooklin.-Between Sedgwick and Bluehill Bay, at eastern entrance of Eggemoggin Reach.

Brooksville._Between Sedgwick and Penobseot Bay, western entrance to Eggemoggin Reach, Hancock County.

Brunswick.-On Androscoggin River and Casco Bay, Cumberland County.

Bucksport.-On east side of Lower Penobscot River, Hancock County.

Bustin's Istand._Casco Bay, near mouth of Freeport River, off southwest point of Bibber's Island.

Culais River.-Same as St. Croix River.

Cambridge River.--Tributary Umbagog Lake, Oxford County, Upton.

Campobello._-Island, New Brunswick, Passamaquoddy Bay, near Eastport.

C'upe Elizabeth._Marks outer western limit of Casco Bay, Cumberland County.

C'ape Porpoise.-York County, Kennebunkport.

Cupe Rosier.-Upper east side of Penobscot Bay, opposite Islesborough.

Carter Brook.-Tributary Harraseeket River, Cumberland County, Freeport.

Carry Ponds.-Tributary Kennebec River, Somerset County. 
Casco Bay:-A large bay limited on the west by Cape Elizabeth, Cumberland County, and on the east by Cape Small Point, Sagadahoc County.

Castine.-West side of mouth of Penobscot River, Hancock County.

Cathance River.-Tributary Kennebec River, or Merrymeeting Bay, Sagadaboc County, Bowdoinham.

Cathance Stream.-Outlet of Cathance Lake, tributary Dennys River, Washington County.

Center Harbor.-Brooklin, Hancock County.

Chatfin Pond:-Tributary Sebago Lake, Cumberland County, North Windham.

Chamberlain Lake.-Head of Allagash River; also flowing through Telosmis, Telos and Webster Lakes and Webster Brook into East Branch of Penobscot River.

Chandler River.-Small stream in Washington County flowing through Columbia Falls, Centerville and Jonesborough into Mason Bay.

Chepednic Lake.-Grand Lake, East Branch St. Croix, same as Chepednecticook.

Cherryfield.-On Narraguagus River, Washington County.

Chickawaka Lake.-Linox County, Rockland.

Churchill Lake.-One of the Allagash River Lakes.

Clapboard Istand.-Near Falmouth shore, Casco Bay.

Clearwater Pond.-Tributary Kennebec River, through Sandy River, Franklin County, Industry.

Cobbosseecontee Lake.-Tributary Kennebec River through Cobbosseecontee River, Kennebec County, Monmouth.

Cochnewagan Lake.-Tributary Cobbosseecontee Lake, Kennebec County, Winthrop. 
Cod Ledges.-A rocky ridge having an average depth of seven fathoms of water, beginning about three miles east of Cape Elizabeth lights and extending northeastward about four miles. Cumberland County.

Craig's Pond.-Tributary Alamoosook Lake, through Craig's Brook, Hancock County, East Orland.

Cranberry Isles. - South of Mount Desert Island, Hancock County.

Crooked River.-_Tributary Sebago Lake, Cumberland County, joining Songo River at Songo Lock; outlet Songo Pond, Albany, Oxford County.

Cross Island.-East of mouth of Machias Bay, Cutler, Washington County.

Cross Lake.-One of the Eagle Lakes, tributary Fish River, and St. John, northern Aroostook County, Guerrette.

Cross Lake Thoroughfare.-Stream connecting Salmon Lake with Cross Lake, Aroostook County.

Cross Rock Rupids.-Rapids in St. John River, northern Aroostook County, St. Francis.

Cumberland Mills. - In Westbrook, situated at Ammoncongin Falls on the Presumpscot River. Cumberland County.

Cumberland and Oxford Canal.-Referred to in the catalogue as Old Canal Presumpscot. A canal constructed 18281830, connecting Sebago Lake at "The Basin" with Portland Harbor at Fore River, Stroudwater.

Cupsuptic.-One of Rangeley Lakes, Franklin County.

Cushmen Pond.-Tributary Saco River, Oxford County, Lovell.

Drisy Brook. - Outlet Daisy Pond.

Daisy Pond.-Tributary First Hurd Pond, Piscataquis County. 
Damariscotta.-... On Damariscotta River, Lincoln County.

Damariscotta River.-Lincoln County, Damariscotta.

Debsconea! Lake.-Tributary West Branch of Penobscot River, Piscataquis County.

Deer Isle._Big and Little, in Hancock County, bounded on the north by Eggemoggin Reach, on the east by Jericho, and on the west by East Penobscot Bay; directly north of Isle au Haut.

Dennys River.-Outlet of Meddybemps Lake into Cobscook Bay, Washington County, Meddyluemps, Charlotte and Dennysville.

Dixmont.—Southwest corner Penobscot County.

Donnell's River.-Outlet of Donnell's Pond into Sullivan River, Hancock County, Franklin.

Duck Islends. - South of Mit. Desert, and east of Swan's Island, Hancock County.

Duck Pond.-Tributary through Mill Brook, of Presumpscot River, Cumberland County, now known as Highland Lake, bounded by Westbrook, Windham and Falmouth.

Dyer River.-Tributary Sheepscot River, Lincoln County.

Eagle Istand.-Casco Bay, Cumberland County, Harpswell.

Eagle Lake.--One of Allagash River Lakes, next below Chamberlain, Piscataquis County.

Eagle Lakes._East Branch of Fish River Lakes, tributary St. John River, northern Aroostook County; include Long; Mud, Salmon, Bear, Cross, Square and Eagle Lakes.

East Branch of Penobscot.-Joins Penobscot River at Medwaly, Penobscot County, same as Matagamon River.

East Branch of Royals River.-Tributary Royals River, flowing through Durham and Pownal, commonly known as "The Branch", Androseoggin and Cumberland Counties. 
Eastern River.-Same as Orland River, Hancock County. Eastern Schoodic Lakes.-Tributary St. Croix River, same as East Branch Saint Croix River, Eastern Schoodic chain, etc., North Lake, Grand or Chepednecticook, First Lakes, etc., Aroostook and Washington Counties, near Vanceboro.

East Machias.-A town northeast of and adjacent to Machias, Washington County.

East Muchias River.-Joins Machias River-in Machias not far above Machias Bay, Washington County.

Eastport.-On Moose Island, near Cobscook Bay; most eastern town in State, Washington County.

Ellsworth-On Union River, Hancock County.

Farmington.-On Sandy River, tributary Kennebec River, Franklin County.

Fiddlers Reach.-Narrow place in Kennebec River between the northeast point of Phippsburg, and Daubling Point on the Island of Arrowsic, Sagadahoc County.

First Debsconeag Lake.-See Debsconeag Lakes.

First Hurd Pond.-Tributary West Branch Penobscot River, near Debsconeag Lakes and "Deadwater", Piscataquis County.

Five Islands.-Casco Bay, Cumberland County.

Fla, Island.-Caseo Bay, Cumberland County, Harpswell.

Floods Pond.-Tributary Union River, Haneock County, ()tis.

Freeport.-On Harraseeket River, Cumberland County.

Freeport River.-Sime as Harraseeket River.

Frenchman's Bay._East of Mount Desert, West of Gouldsborough.

Gardne.r's Pond.-Tributary Eastern River, Lincoln County, Wiscasset. 
Georges Banks.-Between Cape Cod, Mass., and Cape Sable, N. S.

Georges Kiver, or St. Georges River.-Waldo and Knox Counties, emptying into St. Georges Bay.

Georgetown.-Between mouths of Kennebec (Sagadahoc) and Sheepscot Rivers, southwest of Boothbay.

Glasier Lake.-Lower of the St. Francis River lakes.

Glenburn.-Eight and one-half miles northwest of Bangor, Penobscot County; Pushaw Pond.

Goddard Brook.--.Tributary Square Lake; Eagle Lakes, A roostook County.

Goose Islands.-Casco Bay, Cumberland County, Harpsivell.

Gott's Istand.-Between Swan's Island and Cranberry Islands, south of Mt. Desert.

Grand Lake.-Tributary West Branch St. Croix River, Washington County.

Grand Lake Stream.-Outlet of Grand Lake, Washington County, Hinkley.

Great Brook.-Tributary Green Lake, Hancock County, Otis.

Great Pond.-One of the Belgrade Lakes, Kennebec County, Belgrade.

Great Spring Brook.-Tributary Eust Branch Penobseot River, one mile below Bowlin Falls, Penobscot County.

Green Lake.-Tributary Union River, Hancock County, Green Lake, etc.

Gulf of Maine.-The great gulf, south of Maine, between Cape Cod, Mass., and Cape Sable, N. S.

Gun Point Ice Company's Pond.-Casco Bay, Cumberland County, Great Island, Harpswell. 
Hale Pond.--Aflluent west Branch of Penobscot River, Piscataquis County.

Hampden.-- West side of Penobscot River below Bangor, Penobscot County.

Hurlow Brook.--Tributary Lake Auburn (?) Auburn.

Harpswell.-A long neck jutting southwest in Caseo Bay, dividing it into Casco Bay proper on the west side, ancl Quahog Bay on the east side.

Harraseeket River.-Same as Freeport River, an arm of Casco Bay, Cumberland County, Freeport. Tributary Brooks are Carter, Hillside, Frost Gulley or Mast Landing, Porter's Landing and Spar Creek.

Herrington River.-Rises in Cherryfield and Columbia, Washington County, flowing into Narraguagus Bay.

Harrison.-On Long Lake, Sebago system, Cumberland County.

Harvey Brook.-Rises in Pownal, entering Caseo Bay in Freeport, Cumberland County.

Hey Brook.-Tributary to Thorough fare connecting Matag. amonsis and Matagamon Lake, Piscataquis County.

Herrin, Gut.--Western mouth St. Georges River to Mosquito Island, between Port Clyde and Georges Islands.

High Gully Brook. - Tributary Maquoit Bay, Casco Bay, Brunswick.

Hillside Brook.-Tributary Harraseeket River, Cumberland Cumty, Freeport.

Hosmer Pond.-Penobscot Bay, Ḱnox County, Rockport.

Hurd Pond.-Same as First Hurd Pond.

Indiun Pond.--Tributary Sebasticook River, Sonterset County, St. Albans.

Industry-OOn Clearwater Pond, tributary Sandy River, a tributary Kennebec, Franklin County. 
Iste au Haut.-A large, high island; the southeastem boundary of east Penobscot Bay. That part of the latter adjoining, between the island and Vinal Haven, or Fox Island, and its approaches is sometimes called Isle au Haut, or Isle of Holt Bay. The island is bounded on the east by Jericho Bay, and to the north it is separated from Deer Isle by a rocky, island-studded passage known as Merchant's Row.

Isle of Holt.--Same as Isle au Haut.

Islesborough.--Long Island, Upper Penobseot Bay, Waldo County.

Jaquish Island.-In Casco Bay, about two miles southeast of South Harpswell.

Joe True Brook.-Branch of Harvey Brook, Cumberland County, Freeport.

Jonesport.--On Mooseabec Reach, between Englishman's and Pleasant Bays, Washington County.

Katahdin Brook.--Tributary Penobseot River, West Branch, Piscataquis County, on west slope of Katahdin Mountain, entering upper end Pokwokamus Deadwater.

Keazer's Lake or Pond.--Tributary Saco River, Oxford County, Lovell.

Kenduskeng River.-Tributary Penobscot River at Bangor.

Kennebago Luke.-Tributary of Mooselnemeguntic.

Kennebago Stream.-Tributary Rangeley Stream, outlet Kennebago Lake, Franklin County.

Kennebec River.--Outlet of Moosehead Lake; second largest river in Maine.

Kittery.---Mouth Piscataqua River, York County; most western coast town in the State.

Lake Aubum.--Tributary Androscoggin River, Androscoggin County, Auburn. 
Lake Richardson.--One of the Rangeley chain, same as Welokenebacook.

Leweys Lake.--West Branch of St. Croix. Most eastern of "Western Schoodic Chain," Washington County, Me., and Princeton, N. B.

Lincolnville.--West side Penobscot Bay, south side Duck Trap Harbor.

Little Beaver Pond.--Tributary Rainbow Lake, Piscataquis County.

Little Goddard Brook.-T'ributary Square Lake, Aroostook County.

Little Pushaw Pond.-Tributary Penobscot River, Penobscot County, Corinth.

Little Sebaryo Lake.-'Tributary Presumpseot River, Cumberland County, North Windham and Gray.

Little Spring Brook.- Tributary Matagamon River on East Branch of Penobscot, Penobscot County, not far below Great Spring lirook.

Lony Pond.- Same as Long Lake, tributary Sebago Lake, through Songo River.

Lubec.-South of Cobscook Bay and Eastport, Washington County.

Lumbo Ledge.-Fishing ground off southeastern part of Casco Bay.

Lunkasoos Lake.- Tributary East Branch Penobseot, Penobscot County, four miles below the Spring Brooks.

Machias River.-Rises in Machias Lakes, and enters Machias Bay at Machiasport, Washington County.

Marpurrowock Stream.- Tributary St. Croix River, outlet to Magurrowock Lake, Washington County, Robbinston and Calais. 
Manchester Forks.-Forks of Kennebee.

Mamn Brook.-W'Tributary Green Lake, Hancock County, Dedham.

Maranacook Lake.-Tributary Cobbosseecontee Lake, Kennebec County, Winthrop.

Matargamon Lake.-Grand Lake or head waters of main Matagamon or East Branch of Penobseot River, Penobseot County.

Mategamonsis Lake.-Second Matagamon Lake, next lake above Matagamon Lake, Piscataquis County.

Matagamon Thoroughfare.-Connects Matagamonsis and Matagamon Lakes.

Matinicus Istand.-O Off mouth of Penobseot Bay, linox County, about southeast of Metinic Island.

Meadow Brook.-A small stream connecting Boyden and Pennamaquan Lakes.

Meddybemps Lake.-Head waters of Dennys River, Washington County, Meddybemps.

Medomac River.-Same as Medomak River, Knox and Lincoln Counties, entering Muscongus Bay.

Medomak River.-Same as Medomac River.

Merrymeeting Bay.-Bay formed by junction of Kennebec, Androscoggin, and several minor rivers, Sagadahoc County.

Metinic Island.--Off western entrance to Penobscot I3ay, Knox County, St. George.

Midale Bay.-Caseo Bay, between Mere Point and Harpswell.

Monthegan Island.-Off Muscongus Bay, Lincoln County.

Mooseubec Ligh,t.-Southeast of Jonesport, Washington County. 
Moosehead Lake.--Hearl water's of Kemnebec River, Somerset and Piscataquis Counties; largest lake in State.

Moosehemayntic Lake.-Second Rangeley Lake, Franklin County.

Moose Pond.-Tributary Sebasticook River, Somerset County, Hartland.

Dorym Bay.-Bluehill, Hancock County.

Mount Desert.-Between Union River, Bluehill and Frenchman's Bays, Hancock County.

Mount Desert Region.-Union River Basin.

Mount Desert Rock.-About twenty miles southward of Nount Desert.

Mousum River.-Rises in Mousim Pond, enters the sea between Kiennebunk and Crescent Beaches, York County.

Mud Brook.-Tributary of Mud Lake, of Eagle Lakes, Aroostook County.

Mud Lake.-Same as Salmon Lake or Bear Iake, Eagle Lakes chain, Aroostook.

Muddy River.-Northern tributary Sebago Lake, Cumberland County.

Muscongus Bay.-Between Pemaquid Point, Lincoln Comnty, and St. George, Knox County. See IVescongus.

Nahmakuntı Stream.-Connects Nalmmakanta Lake with Pemadumcook Lake, Piscataquis County.

Nurraguagus River.--Rises in Narraguagus Lake, entering Narraguagus Bay at Milbridge, Washington County.

New Hurbor.--In town of Bristol, near Pemaquid, Lincoln County.

New Meadows River.--A tidal arm of Casco Bay, between West Bath, Sagadahoc County, and Brunswick, Cumberland County. 
North, Bridgton..... On Long Lake, Sebago system, Cumberland County.

Northport.--West side of Upper Penobscot Bay, Waldo County.

Norway Luke.--Same as Pennesseewassee Lake, tributary Little Androseoggin River, Norway, Oxford County.

Old Canal Presumpscot.--See Cumberland and Oxford Canal.

Old Orchurd.--Beach in York County, east of Saco River.

Oquassa Lake.--Same as Oquossoc Lake.

Oquossoc Lake.-C Uper Rangeley Lake, Franklin County.

Orland.-On Alamoosook Lake and Orland River, Hancock County.

Oiland Falls.--On Orland River, Hancock County.

Orland River.--Outlet Alamoosook Lake into Penobscot River, Hancock County, Orland.

Orrington.--East side of Penobscot River, opposite Hampden, Penobscot County.

Orr's Island.-Casco Bay, Cumberland County, Harpswell.

Owl's Head.--West side Penobscot Bay, South Thomaston, Knox County, at entrance to Rockland Harbor.

Penther Pond.--'Tributary Sebago Lake, through Jordan River, Cumberland County, Raymond.

Passamaquoddy Bay.-Most eastern Maine bay, west part of Bay of Fundy, chiefly in New Brunswick. In Main washes the shores of Lubec, Eastport, Perry and Robbinston.

Patten Bay.--East side of mouth of Union River, Surry, Hancock County.

Patten River.--Outlet of Patten Pond into Union River. Hancock County, Ellsworth.

Patten Stream.--Same as Patten River. 
Pemaquid.--The southeastern promontory of Bristol, between Johns and Muscongus Bays, Lincoln County, Bristol.

Pembroke.--On western side of Cobscook Bay, Washington County.

Pennamaquan Lake.-Empties into Cobseook Bay through Pennamaquan River, Washington County, Perry.

Pennamaquan River.--Outlet Penmamaquan Lake.

Penobscot.--East side of mouth of Penobscot River, Hancock County.

Penobscot River.--Largest river in the State; four principal tributaries are the W est Branch, East Branch, Mattawamkeag and Piscataquis Rivers.

Petit Manan Island.--Directly south of Petit Manan Point, town of Steuben, western Washington County.

Pettenyill Pond.--Tributary Sebago Lake, Cumberland County, North Windham.

Pierce Pond.--Tributary liennebec River, Somerset County.

Pine Point.--Scarborough, Cumberland County.

Piscatupu River.-Boundary river between Maine and New Hampshire, same as Salmon Falls River, York County.

Piscatapuis River.--Tributary Penobscot River at Howland.

Pleasant Lake.--'Tributary Scraggly Lake, Washington County, IVest Branch of St. Croix.

Polwokamus Deadwater.--Dead water of West Branch of Penobscot River, in Katahdin region, Piscataquis County.

Pocumpus Lake.-Between Sysladobsis and Grand Iake, W ashington County.

Pocumpus Thoroughtare.- Thoroughfare between Sysladobsis and Pocumpus Iake, Washington County. 
Pond Island.-MIouth of Kennebec or Sagadahoc River.

Porter's Landing.-On Harraseeket River, an inlet of Casco Bay, Cumberland County, Freeport.

Porter's Landing Brook.-Tributary Harraseeket River at Porter's Landing.

Portland.-On Casco Bay, Cumberland County.

Presumpscot River._-Outlet of Sebago Lake and its system of lakes and ponds, emptying into Casco Bay, between Portland and Falmouth, Cumberland County.

Prospect.-West side of Penobscot River, opposite Bucksport, Waldo County.

Pushaw Pond.-Tributary Penobscot River, Penobscot County, Glenburn or near Old Town.

Ragged Istand.-The southernmost of the two principal Matinicus Islands, known also as South Matinicus and Criehaven.

Rainbow Lake.-A remote lake in a tributary system of the West Branch of Penobscot River, Piscataquis County.

Rainbow Lake Stream.-OUtlet Rainbow Lake.

Rangeley Lake.-Same as Oquossoc Lake, the upper lake of the Rangeley Lakes.

Rangeley Lakes._- Head waters of Androscoggin River, the main chain consisting of Oquossoc, Mooselucmaguntic, Molechunkamunk, Welokenebacook and Umbagog, Franklin and Oxford Counties.

Rangeley Stream. -Connecting Oquossoc with Mooselucmaguntic Lake.

Rankin Rapids._Rapids below (ross Rock in Upper St. John, Aroostook County, near St. Francis.

Rapid River.-Connecting Welokenebacook and Umbagog Lakes, Oxford County. 
Rattlesnake Pond.- Tributary to Panther Pond, Cumberland County, Ratymond.

Reed's Lake.-Same as Green Lake or Reed's Pond.

Reed's Pond.-Same as Green Iake or Reed's Iake.

Richurdson Luke.-Same as Welokenebacook Lake, Rangeley Lakes, Oxford County.

Rishmond's Island.-Off Bowery Beach, Cape Elizabeth, Cumberland County.

Robbinston.--On Passimaquoddy Bay, Washington County.

Rockland.-On Penobscot Bay, Knox County.

Rockland Harbor.-Same as Rockland.

Round Lake.--Or Round Pond, sometimes on maps as Siquare Pund, Allagash system; lowermost lake, Aroostook, County.

Round Pond.--An arm of Muscongus Bay, Bristol.

Royals River.-Tributary Casco Bay, at Yarmouth.

Sabattus Pond.-Tributary Androscoggin River, Androseoggin County, IVales.

S'aco.-Opposite Biddeford, east side of month of Saco River, York County.

Saco $B a y .-$ A slight indentation of the coast line, marked on the northeast by Cape Elizabeth and the southwest by IVood Island and Fletcher's Neck, in Biddeford; washes the shores of Biddeford, Old Orchard, Scarborough and Cape Elizabeth, receiving the waters of Saco and several minor rivers.

Suco River.--Rises in White Mountain of New Hampshire, flows through Maine, entering the ocean at Saco and Biddeford, York County.

St. Francis Lakes.-Expansion of St. Francis River, bounding Maine, Quebec and New Brunswick chiefly; Aroostook 
County bounded by Pobenagamook, Beau and Glasier Lakes.

St. Francis River.-Tributary St. Jolnn River, boundary river of Maine, New Brunswick and Quebec; extreme northern Aroostook County.

St. Croix River.-Rises by two branches east and west in large systems of lakes respectively, forming east boundary of Maine and New Lirunswick, flowing into Passamaquoddy Bay.

St. Georges River.-Rises in St. George Lake or Pond, and flows into St. Georges Bay, between Knox and Lincoln Counties.

Salmon Lake.--One of the East Branch of Fish River, Eagle Lakes, Aroostook County. Same as Mud or Bear Iake.

Sand Bank Brook.--Tributary East Branch of Penobscot about one mile below Hunt Rapids, Penobscot County.

Sandy Point.--West side Penobscot River near mouth, Stockton Springs, Waldo County.

Sandy River.-Tributary Kennebec River in Franklin County.

Sargentville.--On Penobscot Bay, Hancock County.

Schoodic Grand Lake.-Same as Grand Lake of West Branch of St. Croix, Washington County, Hinkley.

Schoodic Lake.-Near Brownville, Penobscot County ; tributary Penobscot River.

Schoodic Lakes.-Series of lakes between Washington County and New Brunswick, head of East Branch of St. Croix River.

Schoodic Point.-Gouldsborough, Hancock County.

Schoodic Istand.-Off Schoodic Point.

Searsport.-On Searsport Harbor, west side of upper Penobscot Bay, Waldo County. 
Scraggly Lake.-Tributary Junior Lake, Penobscot County, near Washington County line, flowing thence into Syslarlobsis lake.

Sebago Lake.-Head waters of Presumpscot River, second largest lake in State, receiving the waters of numerous other lakes and ponds, Cumberland County.

Seliasticook River._Outlet of Sebasticook Lake, Moose and Indian Ponds, Somerset County; tributary Kennebec River.

Sebec Lake.-Tributary Penobscot River, Penobscot County, through Piscataquis River.

Sebec Pond.-Same as Sebec Lake.

Sebec River.-Outlet of Sebec Lake, tributary to Piscataquis River.

Sebois River.-Tributary East Branch of Penobscot River, at head of Wessataquoik Deadwater, outlet of Scraggly Lake, Penobscot County.

Second Hurd Pond.-Tributary first Hurd Pond.

Seguin Istand.-Off mouth Kennebec River, Sagadahoc County.

Sheepscot Bay.-A deep fjord like bay between Georgetown, Sagadahoe County, and Southport, Lincoln County, east of the Kennebee entrance.

Sheepscot River.-Heading principally in Sheepscot Grand Pond, and emptying into Sheepscot Bay near Southport, Lincoln County.

Ship Pond.-Tributary Sebec Lake, Penobscot County, Elliotsville.

Ship Pond Stream._Connecting Ship Pond and Sebec Lake.

Sidney.-On Messalonskee Lake and Kennebec River, Kennebec County.

Simpson Brook.-Tributary Androscoggin River, Cumberland County, Brunswick. 
Skiff Lake.-A New Brunswick lake tributary to First Lake of Schoodic chain.

Skowhegan.-On Kennebec River, Somerset County.

Stillwater River.-Outlet of Pushaw Pond and other waters, tributary Penobscot River, Penobscot County.

Stockton Springs.-West side of mouth of Penobscot River, Waldo County.

Small Point.-Eastern cape or headland of Casco Bay. Same as Phippsburg, Sagadahoc County.

Smith Brook.-Outlet of Haymock Lake, tributary of Eagle Lake, of Allagash River, Piscataquis County.

Somes Sound.-A long estuary in south side Mt. Desert Island.

Songo River.-O (Otlet of Long Lake, tributary Sebago Lake, Cumberland County.

Southard's Pond.-Small tributary of Hale Pond, a tributary of West Branch Penobscot River, Piscataquis County.

South Brewer.-East side Penobscot River, opposite Bangor, Penobscot County.

South Fork of East Branch of Royal River.-Tributary of "The Branch", almost wholly in Freeport, known in various parts of its course by different names, as Davis Mill Stream, Collins Mill Stream, ete.

Square Lake.-One of the Fish River Eagle Lakes, next above Eagle Lake, Aroostook County.

Square Lake Thoroughfare.-Connecting Cross Lake and Square Lake, Aroostook County.

Sturdivant's Island.-Near the Cumberland shore, Caseo Bay.

Sullivan River.-A long, narrow arm of Frenchman's Bay, 
receiving the waters of several groups of ponds, Hancock County, Sullivan.

Surry.-East side of mouth of Union River, Hancock County.

Swan Lake.-Tributary Lower Penobscot River, Waldo County, Swanville, near Belfast.

Sysladobsis Lake.--One of the western St. Croix system, Washington County, otherwise known as Dobsis or Dobsy.

Sysladobsissis Lake.-Little Sysladobsis, same as Little Dobsis or Little Dobsy.

Tuylur Pond.-Tributary Androscoggin River, Androseoggin County, Auburn.

Telos Lake.-Connected with Chamberlain Lake by thoroughfares, as Telosmis or Round Pond, and with Webster Lake by a stream called "The Cut-Out", Piscataquis County.

Thomas Pond.-Tributary Sebago Lake, Cumberland County, South Casco.

Thompson Pond.-Tributary Little Androscoggin River, Oxford, Cumberland and Androscoggin Counties, Oxford, Otisfield and Poland.

Toddy Pond.-Tributary Alamoosook Lake, Hancock County, Bluehill, Penobscot and Orland.

Tomah Stream.-Tributary West Branch of St. Croix River, Washington County.

Trip Pond.-Tributary Little Androscoggin River, Androscoggin County, Poland.

Tunk Lake.-Same as Tunk Pond, tributary Gouldshorough Bay through Tunk Stream, Haneock County, Tunk Pond Station.

Thnk River.-Same as Tunk Stream, outlet of Tunk Lake.

L'mbagry Lake.-Lowest or southernmost of Rangeley Lakes chain, head of Androseoggin River, Oxford County, Maine, and Coos County, New Hampshire. 
Umbagog System of Lakes.-Same as Rangeley Lakes.

Umsaskis Lake.-One of the Allagash River series next below Churchill Lake, Aroostook County.

Union River.-Rising by three branches, East Branch in Spectacle Pond, Middle Branch in ponds in Aurora, and the main branch or West Branch, in a group of lakes in Great Pond Plantation, empties into Union River Bay, Hancock County.

Varnum Pond.-Tributary Sandy River, Franklin County, Farmington.

Verona.-On an island, at mouth of Penobscot River, south of Bucksport, Hancock County.

Vinal Haven.-The southernmost of two large islands in Penobscot Bay, originally known as the Fox Islands as named by Martin Pring, in 1603 (June 7). The Fox Islands divide Penobscot Bay into East and West Penobscot Bays. The islands belong to Knox County.

Waldoboro.-On Medomak River, Lincoln County.

Wescongus River.--Same as Muscongus River, flowing into Muscongus Bay, Lincoln County.

Wroster Lake.-Tributary East Branch of Penobscot River, through Webster Brook into Matagamonsis, or Second Lake, Piscataquis County.

West Bay.-West part of Gouldsborough Bay, Hancock County, Gouldsborough.

West Branch of St. Croix River.-Draining Western Grand Lake system, tributary St. Croix River, Washington County.

West Carry Pond.-See Carry Ponds.

West Gouldsborough.--On easterly side of Frenchman's Bay, Hancock County.

West Musquash Lake.-One of the Western Grand Lake system, through West Musquash Stream emptying into Big Lake, Washington County, Talmadge. 
Whaldiout Island.-Casco Bay, Cumberland County, Harpswell.

White Head.-An island in St. George, ten miles south of Rockland, at the southwestern entrance to Mussel Ridge Cbannel, on the southern passage to and from Rockland harbor. "The Mud", a local fishing ground, is a large tract of muddy bottom, in sixteen to twenty-one fathoms of water, and directly south of the island one mile distant.

Wild River.-Tributary Androseoggin River, rising in mountains of New Hampshire, and Oxford County, Maine.

Wilton Pond.-.Same as Wilson Pond; tributary Sandy River, Franklin County, Wilton.

Winkempangh Brook.-Tributary Branch Pond, Hancock County, Dedham.

Winnegance Creek.-A brackish tributary of the lower Kiennebee Iiver, between West Bath and Phippsburg, Sagadahoc County.

Winterport. - Lower Penobseot River, Waldo County.

Wissataquoik Deadwater.-East Branch of Penobscot River, between mouth of Wissataquoik River and mouth of Sebois River, Penobscot County, east Mount Katahdin region.

Wissataquoik River.-Rises on north slope of Katahdin Mountain; tributary of East Branch of Penobscot River, just above Hunt Rapids.

Wolf's Neck.-Point of land south side of Harraseeket River, Cumberland County, Freeport.

Wood Island.-Casco Bay, Sagadahoc County, near Small Point.

York River.-Rises in York Pond, flows into York Harbor, York County, York.

Yellow Rock.-Near Eastport, Washington County. 


\section{BIBLIOGRAPHY AND RECORDS.}

References with the authors' names appearing in small capitals are based upon published records. Those with the authors names appearing in italics are based upon records heretofore unpublished. The species named in the various records are numbered and named in the nomenclature of the present catalogue, followed by the word "as" and the nomenclature of the author, or the label of the specimen.

\section{Josselyn, John.}

New England's Rarities Discovered. In Birds, Beasts, Fishes, Serpents and Plants of that Country. Together with the Physical and Chyrurgical Remedies wherewith the Natives constantly use to Cure their Distempers, Wounds and Sores. Also a perfect Description of an Indian squa, in all her Bravery; with a Poem not improperly conferr'd upon her. Lastly a Chronological Table of the most remarkable Passages in that Country amongst the English. Illustrated with Cuts. By John Josselyn, Gent.

London, Printed for G. Widdowes at the Green Dragon in St. Paul's Churchyard, 1672.

The list of fishes, a nominal catalogue in the vernacular of the period, begins at page 23, under the caption, "Thirdly, of Fishes." A sub-heading gives the nature of the list in the following terms: "A Catalogue of Fish, that is, of those that are to be seen between the English Coast and America, and those proper to the Country." The list, which includes several mammals, mollusks, and crustaceans, is followed by a compendium of imagined or traditional medicinal virtues of many species. 
A reprint of the first edition, edited by Edw. Tuckerman, 1860. Transactions and Collections American Antiquarian Society, Vol. IV, pp. 105-238.

Another reprint by Tuckerman. Boston, William Veazie, 1865.

A second edition. London, 1675.

1674. JOSSELYN, JoHs.

An Account of Two Voyages to New England. Wherein you have the setting out of a Ship, With the charges; the prices of all necessaries for furnishing a Planter \& his Family at his first coming; a Description of the Country, Natives and Creatures, with their Mercantile and Physical use; the Government of the Countrey as it is now possessed by the English, \&c. A large Chronological Table of the most remarkable passages from the first discovering of the Continent of America to the year 1673. By Jolm Josselyn, Gent. [Quotation, six lines.]

London, Printed for Giles Widdowes at the Green Dragon in St. Paul's Churchyard, 1674.

Fishes are treated, pages 103-115. At pages 113-115, a list of 66 New England fishes is given. This list, like that of New England Rarities, 1672, contains several mammals, mollusks, crustaceans and echinoderms, and abounds in medicinal allusions.

Second edition. London, 1675.

A reprint of the 1675 edition occurs in Massachusetts Historical Society's Collections, Third Series, Vol. III, 1833 [pp. 211-396]. Here the list of fishes appears on pages 271277.

1675. Josselyn, John.

New England's Rarities Discovered, etc.

Second edition. London. See 1672. 
1675. Josselyn, JoHn.

An Account of Two Voyages to New England, etc.

Second edition. See 1674 .

In this edition "Creatures" is followed by a semicolon; the words, "with their Mereantile and Physical use," are omitted. After "John Josselyn, Gent." are the words "The Second Addition". Otherwise same title as 1674.

\section{Suldivan, James.}

The History of the District of Maine. Illustrated by a new correct map of the district.

Boston, 17.95.

Scattered notes on the salmon, sturgeon and alewife fisheries at Kittery, Saco, Kennebec and Sheepscot Rivers, and the cessation of the salmon fishery with damming of the rivers.

List of species:

Salmo salar

as Salmon

Acipenser sturio as Sturgeon

Pomolobus pseudoharengus as Alewife

Aloșa sapidissima as Shad

Osmerus mordax as Smelt

Microgadus tomeod as Tomeod or frostfish

1804. Peck, Willian D.

Descriptions of four remarkable fishes taken near the Piscataqua in New Hampshire.

Memoirs American Academy of Arts and Sciences, Vol. II, Part 2, p. 48.

List of species: Cryptacanthodes maculatus as Ophidium imberbe Zoarces anguillaris as Blennius anguillaris Poronotus triacanthus as Stromateus triacanthus

Catostomus commersonii as Cyprinus catostomus 
1818. Mitchill, Sanuel I.

Original communications.

American Monthly Magazine and Critical Review, Vol. II, Part 2, February, 1818, p. 244.

[Lota maculosa as Gadus lacustris (type) collected in Sebago Pond by Henry A. S. Dearborn, Esq.]

1832. M.

Salmon Trout--Sebago Lake.

American 'Turf Register and Sporting Magazine, Vol. III, No. 10, June, 1832, pp. 526-529.

The writer of this article, a captain (?) at Fort Preble, has given the first known account of Salmo sebago. He said: "This fish partly resembles in habit and appearance, as the name imports, both the salmon and the brook trout, being perhaps an intermediate species, and varies from two to fourteen pounds weight."

"The fish of this beautiful lake are, so far as my observation extends, essentially different from those of any other."

\section{Williamson, Williand D.}

The History of the State of Maine, from its First Discovery, A. D. 1602, to the Separation, A. D. 1820, inclusive, by William D. Williamson, in two volumes, published by Glazier, Masters \& Co., Hallowell.

The chapter on fishes occurs in Vol. I, pp. 150-164. 
NOMINAL SPECIES.

1. Blennius Chætodon

2. Blennius Anguillarius

3. Anarbichas lupus

4. Gadus Morrhua

5. Gadus æglesinus

6. Gadus polachius

7. Gadus virens

8. Gadus molva

9. Gadus luscus

10. Gadus

11. Freshwater cusk

12. Petromyzon Fluviatalis

13. Petromyzon Marinus

14. Muræna Anguilla

15. Muræna Conger

16. Pleuronectes Flesus

17. Pleuronectes Platessa

18. Pleuronectes Hippoglassus

19. Pleuronectes Papillosus

20. Pleuronectes Squatma

21. Clydopterus Lumpus

22. Scomber scombrus

23. Scomber lanis

-24. Scomber rostratus

25. Cyprinus

26. Cyprinus catostomus forstor

27. Lophius piscatorius

28. Perca fluviatilis

29. Perca lucioperca

30. Perca undulata

:31. Perca alburnus

32. Perca ocellate

33. Perea nobilis

:34. Perca philadelphica

35. Perca chrysoptera

36. Esox lucius

37. Silurus felis

:38. Rubellio fluviatilis

39. Salmo Salar

40. Salmo Trutta

41. Salmo Eperlanus

42. Clupea Aloso

43. Clupea Serrata

IDEN'TIFICATION.

Anarhichas lupus (?)

Zoarces anguillaris (?)

Cryptacanthodes maculatus

Gadus callarias

Melanogrammus æglifinus

Pollachius virens

Pollachius virens

Urophycis tenuis or chuss (?)

Microgadus tomeod

Brosmius brosme

Lota maculosa

Petromyzon marinus

Petromyzon marinus

Anguilla rostrata

Zoarces anguillaris

Pseudopleuronectes americanus

Liopsetta putnami

Hippoglossus hippoglossus

Limanda ferruginea

Raia stabuliforis

Cyclopterus lumpus

Scomber scombrus

Thunnus thynnus

Tylosurus marinus

Various Cyprinidæ

Catostomus commersonii

Lophius piscatorius

Perca flavescens

Morone americana

Morone americana

Merluccius bilinearis

Roccus lineatus

Abramis crysoleucas (?)

Semotilus bullaris

Lepomis gibbosus

Esox reticulatus

Ameiurus nebulosus

Semotilus bullaris

Salmo salar

Salvelinus namaycush (?)

Osmerus mordax

Alosa sapidissima

Pomolobus pseudoharengus 
44. Clupea Harengus

45. Clupea Dura Mystax

4i. Clupea Minima

47. Clupea Menida (?)

4.. Atherina

49. Squalus Stellaris

50. Squalus Acanthias

51. Squalus Xiphias

52. Gasterosteus Solatrix

5:). Gasterosteus Aculeatus

54. Acipenser sturio

5.). Cottus quadricornis

56. Clydopterus (?)

57. Raja Fullonica

58. Pisces rana

59. Troeta
Clupea harengus

Pomolobus mediocris (?)

Clupea harengus (Young)

Brevoortia tyrannus

Menidia menidia notata

Alopias vulpes

Squalus acanthias

Xiphias gladius

Poronotus triacanthus

Gasterosteus aculeatus

Acipenser sturio

Myox ocephalus octodecimspinosus Orthagoriscus mola

Tautogolabrus adspersus

Hemitripterus americanus

Salvelinus fontinalis

\section{Josselya, JònN.}

An Account of 'Two Voyages to New England, etc.

Massachusetts Historical Society's Collections, Vol. III, Third Series [pp. 211-396].

A reprint of the second edition of 1675 . See Josselyn, 1674 , of this bibliography.

List of fishes occurs on pp. 271-277.

1837. Storer, D. Humphreys.

Deseription of a New Species of the Genus Gasterosteus.

Boston Journal of Natural History, Vol. I, 1837, p. 464. [Pungitius punyitius as Gasterosteus Mainensis (type).]

1844. Lindsley, Rev. Jayes H., A. M.

Catalogue of the Fishes of Connecticut, arranged according to the natural families. Prepared for the Yale Natural History Society.

American Journal of Sciences and Arts, Vol. XLVII, pp. $55-80$.

[Black-nosed spotted dace, Semotilus atromaculatus as Leuciscus atromaculata, is mentioned from Maine, pp. 67-68.] 
1845. BatcheLdeR, J. M.

A Description of a New Species of Argyreiosus.

Proceedings Boston Society of Natural History, Vol. II, 1845, p. 78.

[Vomer setapinnis as Argyreiosus unimaculatus (Young), type from Saco, Maine.]

1845. StORER, Dr. [D. H.].

Proceedings Boston Society of Natural History, Vol. II, p. 72 .

Abstract of verbal remarks on Alutera schopfii as Balistes aurantiacus in Massachusetts, and exhibiting drawing of a specimen taken by Dr. Bates, in Portland Harbor, Maine.

18t5. Storer, D. H.

A New Species of Leptocephalus.

Proceedings Boston Society of Natural History, Vol. II, 1845 , p. 76 .

[Leptocephalus conger as Leptocephalus gracilis. 'Type from Cherryfield, Maine.]

1845. Wrinan, Dr. [Jeffries].

Proceedings Boston Society of Natural History, Vol. I, p. 196.

Abstract of verbal communication on chub's nests observed in Magalloway River.

1846. Storer, David Humphreys.

A Synopsis of the Fishes of North America.

Memoirs American Academy of Arts and Sciences, New Series, Vol. II, pp. 253-550 (Cambridge, 1846).

Reissued, repaged 1-298. Cambridge: Metcalf and Company, 1846. 
List of species:

Myoxocephalus groenlandicus as Cottus Groenlandicus

Pungitius pungitius

Scomber scombrus

Zoarces anguillaris

Anarbichas lupus

Lophius piscatorius

Batrachus tau

Tautogolabrus adspersus

Tautoga onitis

Ameiurus nebulosus

Salmo salar

Salvelinus fontinalis

Osmerus mordax

Alosa sapidissima

Brevoortia tyrannus

Gadus callarias

Melanogrammus reglefinus

Microgadus tomeod

Hippoglossus hippoglossus

Cyclopterus lumpus

Alutera schœpfii

Vomer setapinnis

Leptocephalus conger as Gasterosteus Mainensis

as Scomber vernalis

as Zoarces anguillaris

as Anarrhicas lupus

as Lophius Americanus

as Batrachus tau

as Ctenolabrus ceruleus

as Tautoga Americana

as Pimelodus catus

as Salmo salar

as Salmo fontinalis

as Osmerus viridescens

as Alosa sapidissima

as Alosa menhaden

as Morrhua Americana

as Morrhua æglefinus

as Morrhua pruinosa

as Hippoglossus vulgaris

as Lumpus anglorum

as Monocanthus aurantiacus

as Argyreiosus unimaculatus

as Leptocephalus gracilis

1846. WoOd, Dr. William.

A description of a species of shark supposed by him to be hitherto undescribed.

Proceedings Boston Society of Natural History, Vol. II, 1. 174 .

Dr. Wood proposed the name Leiodon echinatum [Somniosus brevipinna] for the specimen, taken about eighty miles east of Portland, regarding it as the type of a new genus and species. 
1848. Storer, Dr. [H. D.].

Abstract of verbal communication identifying the shark described by Dr. Wood [Wood, 18t6] with Sommiosus brevipinna (LeSueur).

Proceedings Boston Society of Natural History, Vol. III, pp. 15-16.

1849. Girard, Mr.

On the Genus Cottus.

Proceedings Boston Society of Natural History, Vol. III, pp. 183-190.

Acanthocottus Gronlandicus.

1851. Eaton, Crrus, A. M.

Annals of Warren with the Early History of St. George's, Broad Bay, and the neighboring settlements on the Waldo Patent.

Hallowell, Masters, Smith \& Co.

Scattered notes on the importance and regulation of the fisheries, their early destruction and protective measures, the earliest fish ways, and fish wardens, with a table of vernal progress in the different seasons from 1805-1850, showing the appearance of the alewives in 1810, and from 1820 to 1850 inclusive. Pickerel said to have been introduced a few years prior to 1832 .

List of species :

Petromyzon marinus

Acipenser sturio

as Lamprey

A.meiurus nebulosus

as Sturgeon

Catostomus commersonii as Sucker

Cyprinidæ and

Poeciliidae as

as $\left\{\begin{array}{l}\text { Roach, chub, } \\ \text { Shiners and minnows }\end{array}\right.$

Anguilla rostrata

as Eel 


\begin{tabular}{|c|c|c|}
\hline Pomolobusp seudoharengus & & Alewife \\
\hline Pomolobus restivalis & as & Blueback \\
\hline Alosa sapidissima & as & Shad \\
\hline Brevoortia tyrannus & as & Menhaden \\
\hline Salmo salar & as & Salmon \\
\hline Salvelinus fontinalis & as & Trout \\
\hline Osmerus mordax & as & Smelt \\
\hline Esox reticulatus & as & Pickerel \\
\hline Perca flavescens & as & Yellow perch \\
\hline Roccus lineatus & as & Bass \\
\hline Morone americana & as & White perch \\
\hline Microgadus tomeod & as & Frostfish or tomcod \\
\hline Pseudopleuronectes & & \\
\hline $\begin{array}{l}\text { americana (?) and } \\
\text { Liopsetta putnami }\end{array}$ & as & Flounders \\
\hline Tylosurus marinus & as & Garfish \\
\hline
\end{tabular}

1852. Perley, M. H.

Descriptive Catalogue (in part) of the Fishes of New Brunswick and Nova Scotia.

Second edition, 1852, pp. 1-50.

List of species :

Sebastes marinus

Tautogolabrus adspersus

Tautoga onitis

Ameiurus nebulosus

Salvelinus namayeush

Coregonus labradoricus

Pomolobus mediocris

Melanogrammus æglifinus

Pollachius virens

Lota maculosa

as Sebastes norwegicus

as Ctenolabrus cæruleus

as Tautoga americana

as Pimelodus catus

as Salmo ferox

as Coregonus albus

as Alosa mattawaca

as Morrhua aglefinis

as Merlangus carbonarius

as Lota maculosa

Hippoglossus hippoglossus as Hippoglossus vulgaris 
1852. Wheatland, Henry.

Notice on Several Fishes of Rare Occurrence.

Journal Essex County Natural History Society, Vol. I, p. 124.

[Leptocephahus conger as Leptocephatus gracilis, Cherryfield, Maine. "From a basin formed in a timber raft."]

1853. Girard, Charles.

Notice of a New Species of Salmonidæe from Maine.

Proceedings Boston Society of Natural History, Vol. IV, 1851-1854, p. 262. (Read October 20, 1852; published 1830.)

[Salvelinus oquassa as Salmo oquassa (type.)]

1853b. Girard, Charles.

Description of a Supposed New Species of Salmo.

Proceedings Academy of Natural Science, Philadelphia, Vol. VI, 1853, p. 380.

[Salmo sebago as Salmo sebago (type).]

\section{3 (?). Hamlin, Augustus C.}

Brochure on the togue. [Title unknown.]

Holmes' discussion of the togue, under the name of "Salmo toma, Hamlin", in Natural History and Geology of Maine (1862), pp. 109-112, is therein stated to be copied from a brochure on the togue, published by A. C. Hamlin, M. D., Bangor, but the date of publication is not given. Hamlin, however (1903), refers to his brochure on the togue of "about 50 years ago". The present author has tried in vain to find a copy of this privately printed paper, therefore the date is taken from Hamlin's statement, which may not be exact.

1853. Storer, D. Humphrey.

A History of the Fishes of Massachusetts. Parts 1 and 2. 
Memoirs American Academy of Arts and Sciences, New Series, Vol. V.

Part 1, pp. 49-92, pls. 1-8; Part 2, pp. 122-168, pls. 9-16.

In reprint $1867 \mathrm{~A}$. Comprised in pp. 1-91.

List of species :

Perca flavescens

Roceus lineatus

as Perca flavescens

Morone americana

as Labrax lineatus

as Labrax rufus

Myoxocephalus grœnlandicus as Acanthocottus variabilis

Hemitripterus americanus

Sebastes marinus

Pungitius pungitius

Scomber scombrus

Scomberomorus maculatus

Vomer setapinnis

Pomatomus saltatrix

Menidia menidia notata as Hemitripterus Acrdianus

as Sebastes Norvegicus

as Gasterosteus Dekayi

as Scomber vernalis

as Cybium maculatum

as Argyreiosus unimaculatus

as Temnodon saltator

as Atherina notata

\section{U. S. Nutional Museum.}

Record Book, Department of Fishes, U. S. N. M., Vol. I. A wrymouth (Cryptacanthodes maculatus) is recorded as collected in Maine by Wm. Stimpson, but there is no date. The probability is that it was collected at Eastport about 1852 or 1853.

\section{Girard, Charles.}

Notice of a New Species of Salmonidæ, from the northeastern part of the United States.

Proceedings Academy of Natural Science, Philadelphia, Vol. VII, 1854, pp. 85-86.

[Salmo salar (Young) as Salmo gloveri. Type from Union River, Maine.] 
1855. Storer, D. Humphreys.

A History of the Fishes of Massachusetts. Part 3, 1855. Memoirs American Academy of Arts and Sciences, New Series, Vol. V, pp. 257-296, pls. 17-23.

In reprint $1867 \mathrm{~A}$. Comprised in pp. 92-131.

List of species:

Pholis gunneilus

Zoarces anguillaris

as Gunnellus mucronatus

Anarhichas lupus

Lophius piscatorius as Zoarces anguillaris

as Anarrhichas vomerinus

Opsanus tau

as Lophius Americanus

as Batrachus tau

Tautogolabrus adspersus

Tautoga onitis

as Cteriolabrus ceruleus

as Tautoga Americana

Ameiurus nebulosus

as Pimelodus atrarius

1856.

Donations to the Museum.

Proceedings Boston Society of Natural History, Vol. V, p. 399.

Four specimens of Salmo erythrogaster, lake trout, as Salvelinus fontinalis, from Moosehead Lake, by Dr. Augustus C. Hamlin, of Bangor.

\section{7. [KNEELAND.]}

Donations to the Museum.

Proceedings Boston Society of Natural History, Vol. VI, p. 45 .

Fishes from Moosehead Lake, Great Schoodic Lakes, Penobscot River and sea near its mouth, by Dr. Kneeland, jr.

List of species:

Salvelinus fontinalis

Salvelinus fontinalis

Osmerus mordax

(?) as Salmo erythrogaster

as Salmo fontinalis

as Smelts

as Alosa, three species, 
1858. STORER, D. HumphreYs.

A History of the Fishes of Massachusetts. Part 4, 1858. Memoirs American Acadeny of Arts and Sciences, New Series, Vol. VI, pp. 309-372, pls. 24, 29.

In reprint $1867 \mathrm{~A}$. Comprised in pp. 132-195.

List of species:

Esox reticulatus

Salmo salar

Salvelinus fontinalis

Osmerus mordax

Alosa sapidissima

Brevoortia tyrannus

Gadus callarias

Melanogrammus aglefinus

Microgadus tomcod

Pollachius virens

Urophycis tenuis

Ilippoglossus hippoglossus

as Esox reticulatus

as Salmo salar

as Salmo fontinalis

as Osmerus viridescens

as Alosa prestabilis

as Alosa menhaden

as Morrhua Americana

as Morrhua æglefinus

as Morrhua pruinosa

as Merlangus purpureus

as Phycis Americanus

as Hippoglossus vulgaris

\section{Herbert, William Henry.}

Frank Forester's Fish and Fishing of the United States and British Provinces of North America. Illustrated from nature. New edition, revised and corrected, with ample supplement by the author, together with a Treatise on Fly Fishing, by "Dinks", 1859, pp. i-xxiv, 1-512.

[Salmo sebago.]

1860 .

Donations to the Museum.

Proceedings Boston Society Natural History, Vol. VII, p. 429.

A young salmon from Sebago Lake, by Walter Brackett. [Salmo sebago.] 
1860. Josselyn, JoHN.

New England's Rarities Discovered [etc.] With an Introduction and Notes by Edward Tuckerman.

Transactions and Collections American Antiquarian Society, Vol. IV, pp. 105-238.

A reprint of the first edition (1672) edited by Edward Tuckerman.

1861. Holmes, E.

Notes and Sketches of the Wild Land Explored.

Preliminary Report upon the Natural History and Geology of the State of Maine, 1861, pp. 331-360.

[Coregonus labradoricus as Coregonus albus, collected by Manly Hardy and Louis Ketchum, p. 353.]

\section{2. Нгтснсоск, С. Н.}

Geology of Maine.

Second Annual Report upon the Natural History and Geology of the State of Maine, 1862, pp. 323-430. The following list of fishes oçcurs at p. 328.

List of species :

Salvelinus oquassa

Semotilus bullaris (?)

Catostomus catostomus as Salmo oquassa

as Uncommon variety of dace as $\mathrm{A}$ red-sided sucker

1862. Holnes, Dr. Ezekiel.

Report on the Fishes of Maine, including some of the Elementary Principles of Ichthyology.

Natural History and Geology of Maine, Second Annual Report, 1862, pp. 11-117. 


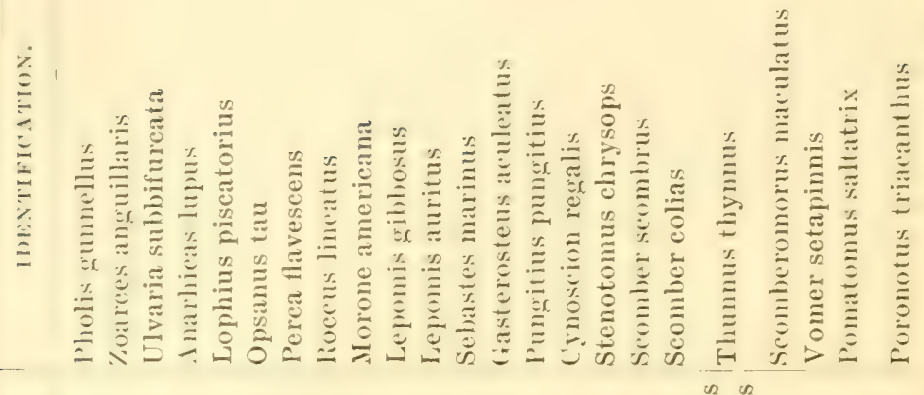

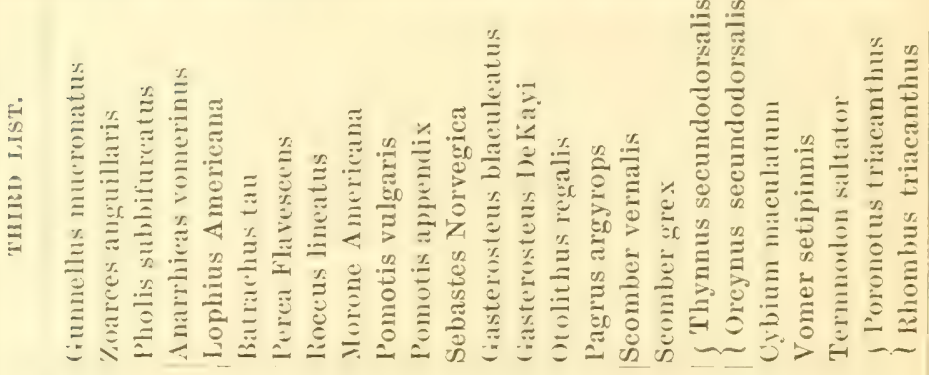

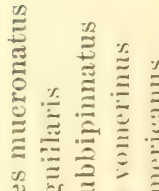

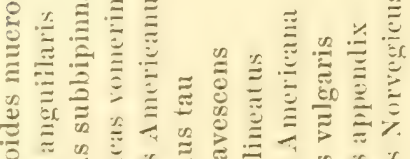

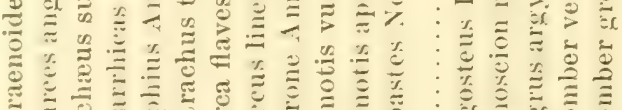

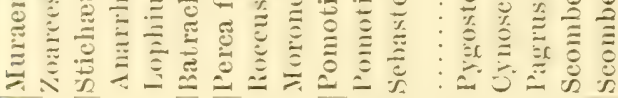

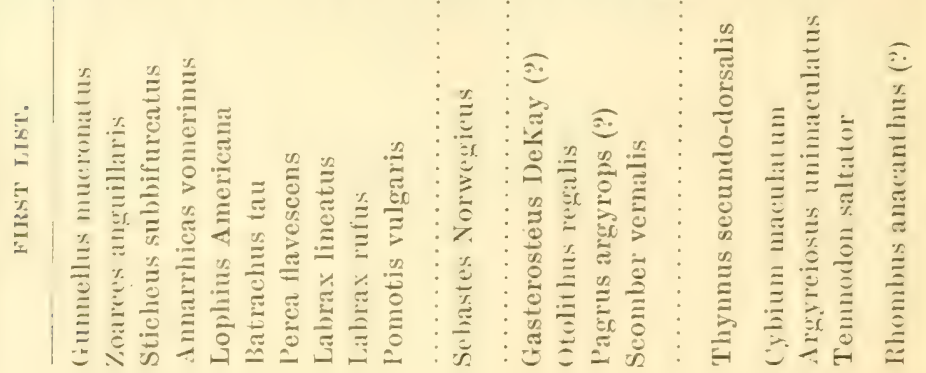


Kendall: Fishes of Maine.

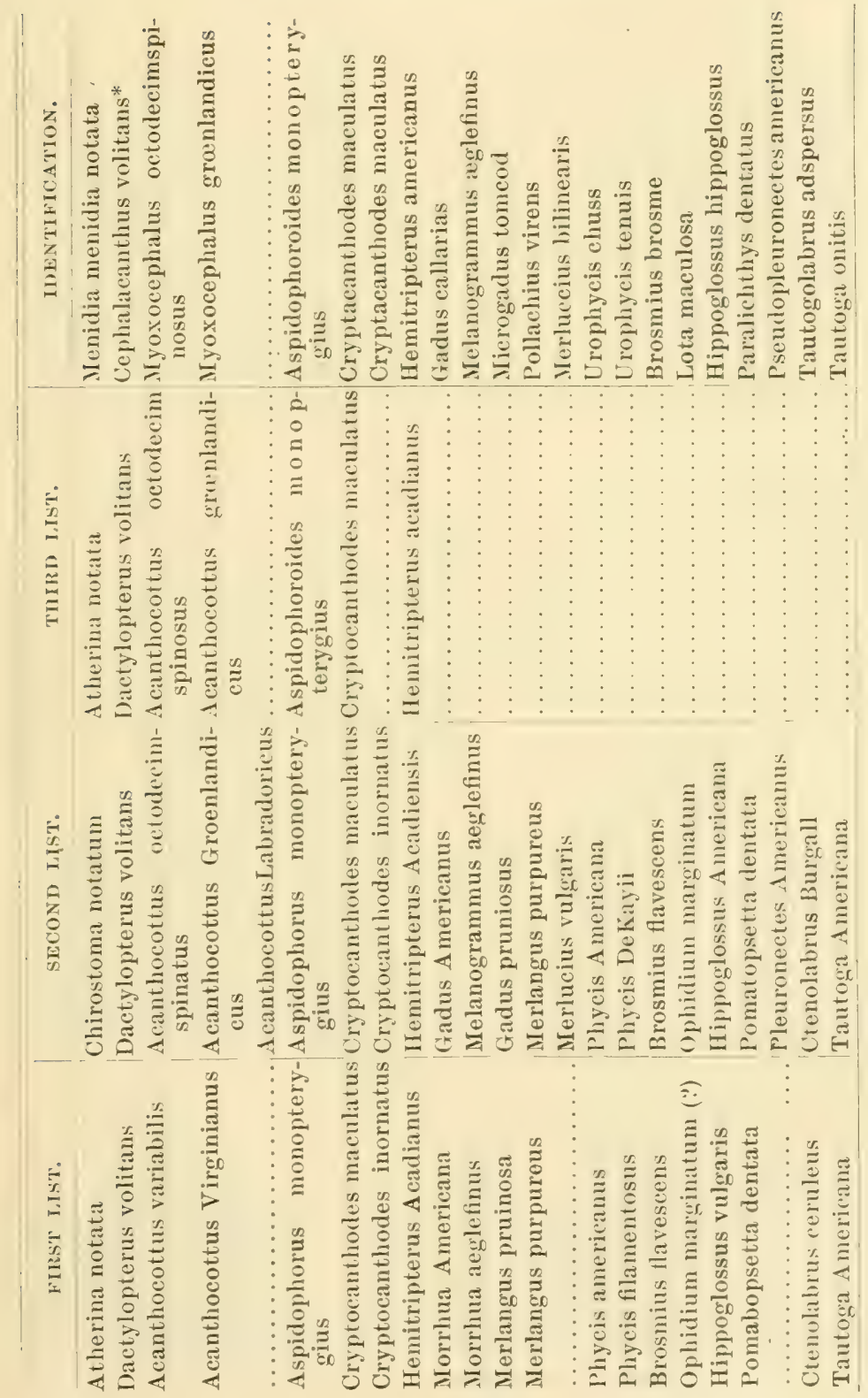




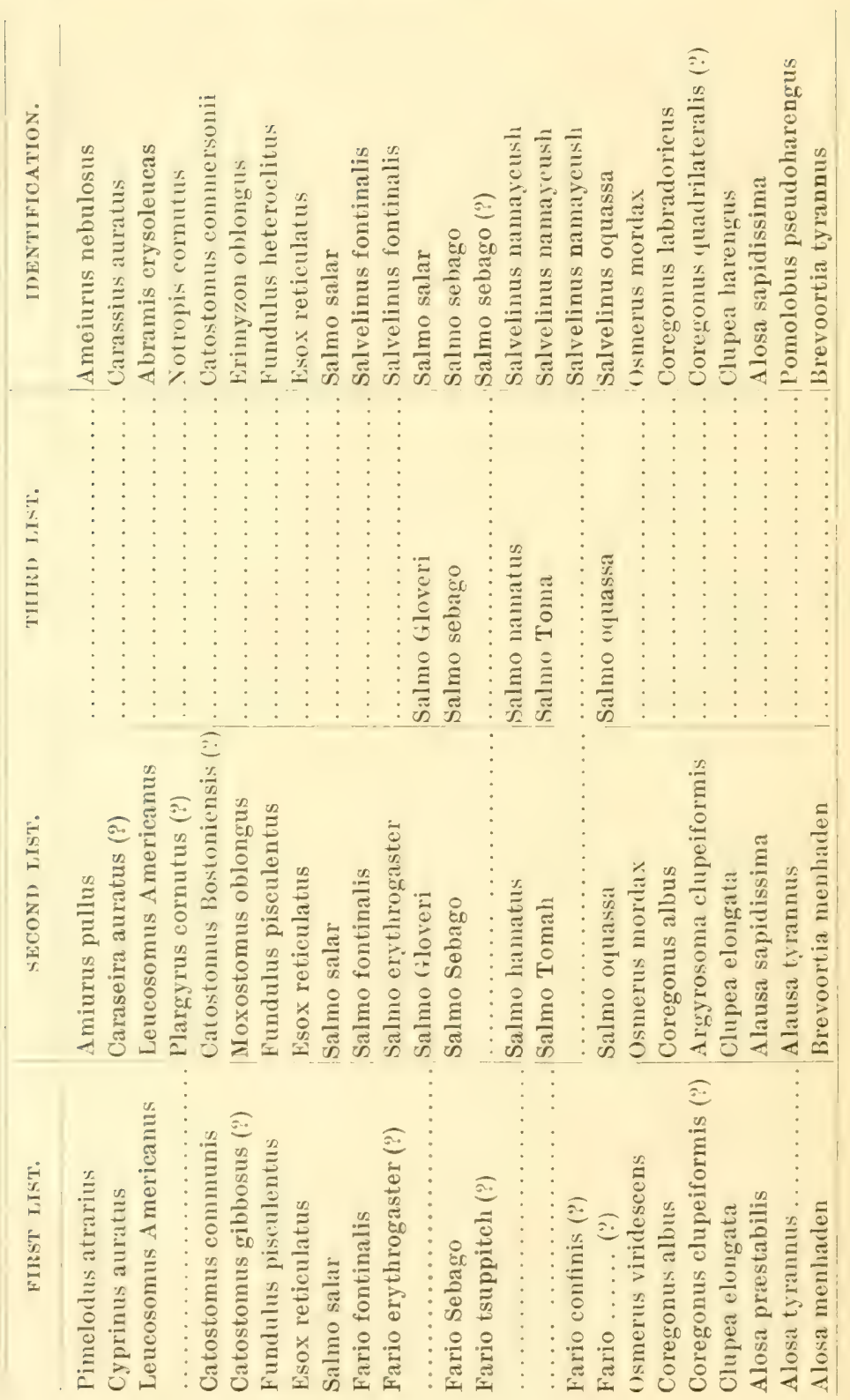




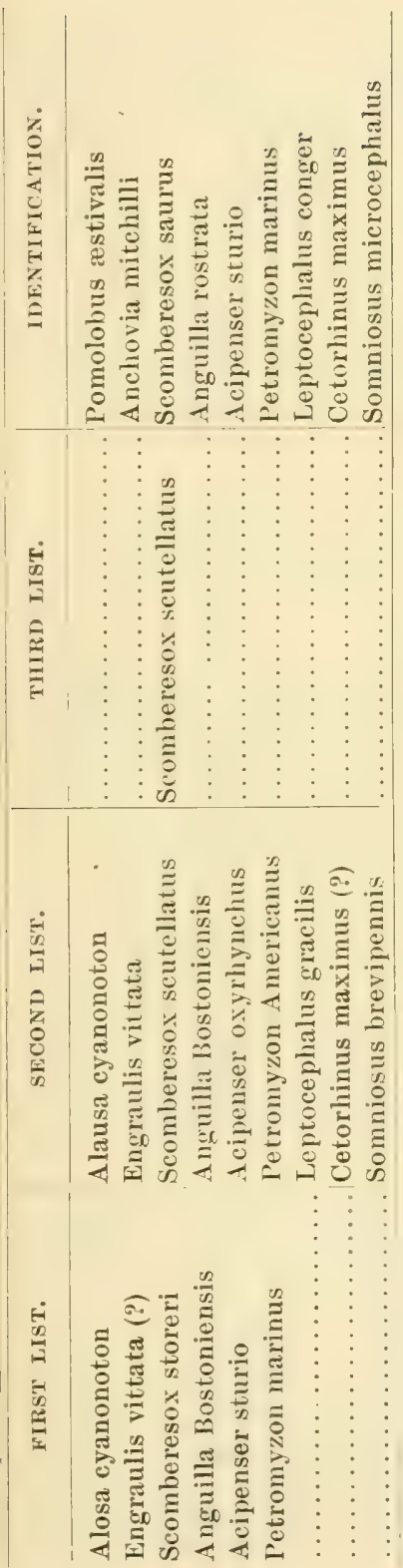


1863. STORER, J. HUMPHREYS.

A History of the Fishes of Massachusetts. Part V, 1863. Memoirs American Academy of Arts and Sciences, New Series, Vol. VIII, pp. 389-434, pls. 30, 35.

In reprint $1867 \mathrm{~A}$. Comprised in pp. 196-241.

List of species :

Cyclopterus lumpus

Alutera schœpfii

Acipenser sturio

as Lumpus Anglorum

as Monacanthus aurantiacus

as Acipenser oxyrinchus

1865. [ATWOOD, N. E.]

[Meeting] October 19, 1864.

Proceedings Boston Society of Natural History, Vol. X, pp. 65-67.

Abstract of address by Capt. N. E. Atwood, upon Habits of Salt Water Fishes, especially of Mackerel and Menhaden.

List of species:

Scomber scombrus

Scomber colias

as Scomber vernalis

as Scomber grex

1865. JOSSELYN, JOHN.

New England's Rarities Discovered. In Birds, Beasts, Fishes, Serpents and Plants of that Country. With an Introduction and Notes by Edward Tuckerman, M. A. Boston, William Veazie, MDCCCLXV.

A reprint of Josselyn's first (1672) edition. See Josselyn, 1672 , this bibliography.

1865. [PUtxam AxD Pickering.]

[Meeting] October 5, 1864.

Proceedings Boston Society of Natural History, Vol. X, pp. $64-65$.

Abstract of remarks by F. W. Putnam and Dr. Pickering 
on distribution of fishes, Great Lakes, Richardson Chain, Sebago Lake and Androseoggin River.

List of species:

Semotilus bullaris

Notropis cornutus

Lota maculosa

Salmo sebago

as Chub

Esox reticulatus

Anguilla rostrata

as Red fin

as Lota

as Salmo

as Pickerel

as Eel

1866. [Putnan, F. W.]

Donations to Museum.

Proceedings Boston Society of Natural History, Vol. X, p. 164.

Among a large number of specimens presented to the Boston Society of Natural History, January 4, 1865, are mentioned "nine hundred fish . . . from Northern Maine by Mr. F. W. Putnam". (See this bibliography, 1865. [Meeting] October 5, 1864.) Though no names are given, some of the specimens are referred to in the present catalogue as B. S. N. H., Putnam coll.

1866A. [Putnam.]

[Meeting] May 17, 1865.

Proceedings Boston Society of Natural History, Vol. X, p. 181.

Remarks by F. W. Putnam on trout [Salvelinus namaycush (?)] found in Thompson's Pond, Norway, Me.

1867. Atwood, Capt. [N. E.]

"Addressed the Society upon the habits of our native species of the Gadidae."

Proceedings Boston Society of Natural History, Vol. XI, pp. 100-102. 
Mentions the cusk (Brosmius brosme as Bromius vulgaris) off Wells Bay, about Cape Porpoise and. Cashes' Ledge as "not infrequent."

\section{Storer, David HuMPhreys.}

A History of the Fishes of Massachusetts. Part 6.

Memoirs American Academy of Arts and Sciences, New Series, 1867, Vol. IX, pp. 217-263, pls. 36-39.

In the reprint $1867 \mathrm{~A}$, comprised in pp. 242-287.

List of species :

Isurus punctatus

Cetorhinus maximus

Somniosus microcephalus

Neoliparis atlanticus as Lamna punctata

as Selachus maximus

as Scymnus brevipinna

as Liparis (sp. ?) allied to $\mathrm{I}$. arctica

1867A. Storer, David Humphreys.

A History of the Fishes of Massachusetts.

Reprinted from the Memoirs of the American Academy of Arts and Sciences, repaged 1-287, pls. 1-39.

This work was issued in six parts, duly cited in this bibliography. See Storer, 1853, Parts 1 and 2, 1855, 1858, 1863 and 1867.

List of species :

Perca flavescens

as Perca flavescens

Roccus lineatus

Morone americana

as Labrax lineatus

Myoxocephalus gronlandicus as Acanthocottus variabilis

Hemitripterus americanus as Hemitripterus Acadianus

Sebastes marinus as Sebastes norvegicus

Pungitius pungitius

Scomber scombrus

as Gasterosteus Dekayii

as Scomber vernalis

Scomberomorus maculatus

as Cymbium maculatam 
Vomer setapinnis

Pomatomus saltatrix

Menidia menidia notata

Pholis gunnellus

Zoarces anguillaris

Anarhichas lupus

Lophius piscatorius

Opsanus tau

'Tautogolabrus adspersus

Tautoga onitis

Ameiurus nebulosus

Esox reticulatus

Salmo salar

Salvelinus fòntinalis

Osmerus mordax

Alosa sapidissima

Brevoortia tyrannus

Gadus callaris

Melanogrammus æglefinus

Microgadus tomeod

Pollachius virens

Urophycis tenuis

Hippoglossus hippoglossus

Cyclopterus lumpus

Aleutera schœpfii

Acipenser sturio

Isurus punctatus

Cetorhinus maximus

Somniosus microcephalus

Neoliparis atlanticus as Argyreiosus unimaculatus

as Temnodum saltator

as Atherina notata*

as Gunnellus mucronatus

as Zoarces anguillaris

as Anarrhicas vomerinus

as Lophius Americanus

as Batrachus tau

as Ctenolabrus ceruleus

as Tautoga Americana

as Pimelodus atrarius

as Esox reticulatus

as Salmo salar

as Salmo fontinalis

as Osmerus viridescens

as Alosa prestabilis

as Alosa menhaden

as Morrhua Americana

as Morrhua æglefinus

as Merlangus pruinosa

as Merlangus purpureus

as Phycis Americanus

as Hippoglossus vulgaris

as Lumpus Anglorum

as Monacanthus aurantiacus

as Acipenser oxyrinchus

as Lamna punctata

as Selachus Maximus

as Scymnus brevipinna

as Liparis (sp. ?) allied to L. aretica

"Piscataqua River, according to Prof. Peck (?), of "Kittery, N. H." [Maine]. 
1868.

Additions to the museum and library during October, November and December, 1867.

Proceedings Essex Institute, Vol. V, p. 207.

E. Bicknell, Salem. A mackerel shark from Portland Harbor [Isurus nasus (?)].

1868. Foster, Nathan W., and Atkins, Charles G.

First Report of the Commission of Fisheries of the State of Maine, 1867 (1868).

Also issued as Senate Document, No. 7, 1868, and in one volume with the second report, 1869.

Cited as Me. F. C. Report, 1868.

List of species:

Salmo salar

Osmerus mordax

Alosa sapidissima

Pomolobus pseudoharengus

Roceus lineatus

as Salmo salar

Salmo sebago

as Osmerus viridescens

Salvelinus fontinalis

Salvelinus namaycush

Salvelinus oquassa

Osmerus mordax (?)

Coregonus labradoricus

Morone americana

Esox reticulatus

as Alausa prestabilis

as Alausa tyrannus

as Roceus lineatus

as Salmo sebago

as Salmo fontinalis

as Salmo toma

as Salmo oquassa

as Fresh water smelt

as Coregonus

as Morone americana

as Esox reticulatus

1869. Foster, Nathan W., and Atkins, Charles G. Second Report of the Commissioners of Fisheries of the State of Maine, 1868 (1869).

The first and second reports were also issued in one volume, 1869.

Cited as Me. F. C. Report, 1869. 
List of species :

Salmo salar

Salmo salar

Alosa sapidissima

Pomolobus pseudoharengus

Roccus lineatus

Osmerus mordax

Clupea harengus

Pomolobus restivalis

Brevoortia tyrannus

Scomber scombrus

Pomatomus saltatrix

Salmo sebago

Osmerus abbottii

Osmerus mordax

Morone americana

Anguilla rostrata

Salmo sebago as Salmo gloveri

as Salmon

as Shad

as Alewife

as Roceus lineatus

as Smelt

as Herring

as Blueback

as Porgie

as Mackerel

as Bluefish

as Sebago salmon

as Little smelt of Monmouth

as Large smelt of Sidney and Belgrade

as White perch

as Eel

as Schoodic salmon

1870.

Additions to the Museum of the [Essex] Institute and Peabody Academy of Science.

Bulletin Essex Institute, Vol. I, p. 35.

Portland Society of Natural History. Three specimens of Liparis (sp. ?) found among the eelgrass, Portland Harbor, collected by C. B. Fuller.

Charles G. Atkins, living young salmon and eggs of Salmo fontinalis from Grand River, Maine.

1870. Atkins, Charles G.

Third Report of the Commissioner of Fisheries of the State of Maine, 1869 (1870).

This report shows the manner, time and places of the first introduction of black bass into Maine.

Cited as Me. F. C. Report, 1870. 
List of species:

Micropterus dolomieu

Salmo sebago

as Black bass

Pomolobus pseudoharengus as Schoodic salmon

Osmerus mordax

Esox reticulatus

Alosa sapidissima as Alewife as Smelt as Pickerel as Shad

1870a. Atkins, Charles G.

Fourth Report of the Commissioner of Fisheries of the State of Maine for the year 1870 (1870).

Reports a survey of Penobscot River and Matagamon or East Branch for breeding grounds of salmon (Sidmen sula ${ }^{\circ}$ ).

Cited as Me. F. C. Report, 1870A.

List of species:

Pomolobus pseudoharengus as Alewife

Salmo salar as Salmon

Salvelinus fontinalis as Trout

Coregonus labradoricus Semotilus bullaris as Whitefish as Chub

1870. Cope, E. D.

A Partial Synopsis of the Fishes of the Fresh Waters of North Carolina.

Proceedings American Philosophical Society, Vol. XI, 1870, pp. 448-495.

List of species :

Osmerus spectrum

Osmerus abbottii

Osmerus mordax

as Osmerus spectrum (type)

as Osmerus Abbottii (type)

as Osmerus viridescens

18\%0. U. S. National Museum.

Record Books of the Department of Fishes, U. S. N. M. Squalus acanthias. 
1871. REviEWS.

The American Naturalist, Vol. V, pp. 412-414.

Mr. Atkins' Report as Commissioner of Fisheries of the State of Maine.

Salmon, shad and alewife [Salmo salar, Alosa sapidissima and Pomolobus pseudoharengus].

1871. Verrill, A. E.

On the Food and Habits of Some of our Marine Fishes.

The American Naturalist, Vol. V, No. 7, September, 1871, pp. 397--400.

List of species :

Anarhichas lupus as Anarrhichas vomerinus

Myoxoeephalus

Myoxocephalus gronlandicus octodecimspinosus

Melanogrammus rglifinus Pollachius virens Gadus callarias Urophycis tenuis

Sebastes marinus

Clupea harengus

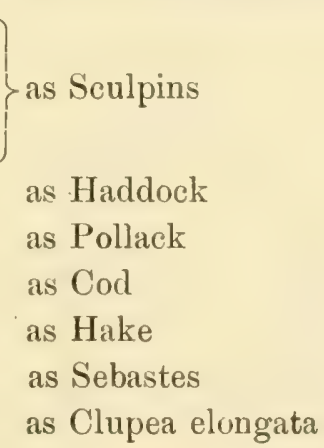

\section{Atrins, Charles G.}

Fifth Report of the Commissioner of Fisheries of the State of Maine, 1871 (1872).

Cited as Me. F. C. Report, 1872.

List of species :

Salmo salar as Salmon

Alosa sapidissima as Shad 
1872. C. G. A[tikins].

Propagation of Salmon.

The American Naturalist, Vol. VI, pp. 170-172.

First attempt to obtain eggs of Salmo salar.

1872A. Stilfell, E. M., and Stanley, Henir O.

Sixth Report of the Commissioners of Fisheries of the State of Maine for the year 1872 (1872).

Contains report of C. G. Atkins on collecting salmon eggs at Bucksport.

Cited as Me. F. C. Report, $1872 \mathrm{~A}$.

List of species :

Salmo salar

as Salmon

Micropterus dolomieu

as Black bass

Pomolobus pseudoharengus as Alewife

18\%. U. S. National Museum.

Fishes from Eastport, Maine, collected by U. S. Fish Commission in 1872 .

Record Books of the Department of Fishes, U. S. N. M., Vol. III.

List of species :

Clupea hatengus

/soarces anguillaris

Hippoglossus hippoglossus

Melanogrammus reglifinus

Myoxocephalus groenlandicus as Cottus gronlandicus

Gymnocanthus tricuspis

Sebastes marinus

Sebastes marinus

Pollachius virens

Pollachius virens

Microgadus tomeod as Clupea elongata

as \%oarces anguillaris

as Hippoglossus americanus

as Melanogrammus reglifinus

as Gymnocanthus patris

as Sebastes norwegicus

as Sebastes viviparus

as Pollachius vulgaris

as Pollachius carbonarius

as Microgadus tomeod 
Scomber scombrus

Cyclopterus lumpus

Poronotus triacanthus

Urophycis tenuis

Raia sp. (?)

Gadus callarias

Lophius piscatorius

Hemitripterus americanus

Pholis gunnellus

Stenotomus chrysops

Osmerus mordax

Salmo salar

Alosa sapidissima

Pomolobus pseudoharengus

Pseudopleuronectes

americanus as Pseudopleuronectes americanus

Merluccius bilinearis

Raia diaphanes

Raia erinacea

Fundulus heteroclitus

Fundulus heteroclitus

Petromyzon marinus

Lumpenus lampatræformis

Aspidophoroides

monopterygius as Aspidophoroides monopterygius

Pomolobus restivalis

Pungitius pungitius

Gasterosteus aculeatus

Squalus acanthias

Apeltes quadracus as Scomber vernalis

as Cyclopterus lumpus

as Poronotus triacanthus

as Phycis tenuis

as Rair maculata? (lævis?)

as Gadus morrhua

as Lophius americanus

as Hemitripterus acadianus

as Murænoides mucronatus

as Stenotomus argyrops

as Osmerus mordax

as Salmo salar

as Alosa sapidissima

as Pomolobus pseudoharengus

as Merlucius bilinearis

as Raia ocellata

as Raia erinacea

as Fundulus heteroclitus

as Hydrargyra majalis

as Petromyzon americanus

as Leptoblennius serpentinus as Pomolobus rstivalis

as Pygosteus occidentalis

as Gasterosteus biaculeatus

as Squalus americanus

as Apeltes quadracus

\section{8'\%2. U. S. National Museum.}

Fishes collected by Sen. Edmonds at Grand Lake Stream, 1872. 
Record Books of the Department of Fishes, U. S. N. M., Vol. III.

List of species:

Salmo sebago

as Salmo sebago

Salvelinus namayeush

as Salmo toma

1872. VERRILL, A. E.

Marine Fauna of Eastport, Me.

Bulletin Essex Institute, Vol. III, pp. 2-6.

A report on the abundance and nature of the invertebrate fauna. The following fishes are mentioned: Clupea harengus as herring, Clupea elongata; Urophycis (sp. ?) as hake; Melanoyrammus aglifinus as haddock; Pollachius virens as pollock; Anarhicas lupus as wolf-fish, Anarhicas vomerinus; Cetorhinus maximus as basking shark, Cetorhinus maximus.

1873. ADAis, A. Leith.

Field and Forest Rambles.

List of species:

Esox reticulatus

Salvelinus namaycush

Salmo sebago

Salmo sebago

Semotilus bullaris

Semotilus bullaris (?)

Rhinichthys atronasus

Notropis cornutus (?)

Gasterosteus atkinsii

Pungitius pungitius

Salvelinus fontinalis

Semotilus sp. (?)

Notropis cornutus

Anguilla rostrata

Catostomus catostomus

Salvelinus oquassa

as Esox reticulatus

as Togue

as Salmo sebago

as Salmo Gloveri

as Silvery dace

as Roach dace

as Brook minnow

as A red-banded species

as Two-spined stickleback

as Nine-spined stickleback

as Trout

as Chub

as Redfin

as Eel

as Catostomus longirostris as Salmo oquassa 
1873. Atkins, Charles G.

On the Salmon of Eastern North America and its Artificial Culture.

Report U. S. Fish Commission, 1872 (1873), pp. 226-337. [Salmo salar.]

1873. Gill, Theodore.

Catalogue of the Fishes of the East Coast of North America.

Smithsonian Miscellaneous Collection, 1873, Vol. XIV, Article II, pp. 1-50.

List of species:

Lophius piscatorius

Limanda ferruginea

Liopsetta putnani

as Lophius americanus

as Myzopsetta ferruginea

as Pleuronectes glaber

Glyptocephalus cynoglossus as Glyptocephalus acadianus

Urophycis tenuis

as Phycis tenuis

Merluccius bilinearis

as Merlucius bilinearis

Zoarces anguillaris

Cryptacanthodes maculatus

Ulvaria subbifureata

as Zoarces anguillaris

as Cryptacanthodes inornatus

as Eumesogrammus

subbifurcatus

Sebastes marinus

as Sebastes viviparus

Vomer setapinnis

as Vomer setipinnis

Palinurichthys perciformis

Poronotus triacanthus

as Palinurichthys perciformis

Menidia menidia notata

as Poronotus triacanthus

Fundulus heteroclitus

as Chirostoma notata

Pomolobus pseudoharengus

Carcharias taurus

as Fundulus pisculentus

as Pomolobus pseudoharengus

as Eugomphodus littoralis

1873. Hallock, Charles.

The Fishing Tourist; Anglers' Guide and Reference Book, 1873. 
List of species:

Salmo sebago

as Salmo gloveri

Salvelinus namayeush

as "Toag"

Salmo sebago (?)

as Salmo sebago

Salvelinus fontinalis

as Salmo fontinalis

1873. Handix, A. C.

On the Salmon of Maine.

Report U. S. Fish Commission, 1872, pp. 338-356.

[Salmo selago as Salmo salar.]

1873. Suchley, Geo.

On the North American Species of Salmon and T'rout.

Report U. S. Fish Commission, 1872 (1873), pp. 91-160.

List of species :

Salmo salar

as Salmo salar

Salvelinus fontinalis

as Salmo fontinalis

Salmo sebago

as Salmo sebago

Salvelinus oquassa

as Salmo oquassa

Salvelinus namaycush

as Lake trout

18\%3. U. S. Netionel Huseum.

Fishes from Casco Bay, Maine, collected by U. S. Fish Commission in 1873.

Record Books of the Department of Fishes, U. S. N. M., Vol. III.

List of species :

Raia sp.

Tautogolabrus adspersus

Isurus tigris

Cyclopterus lumpus

Pholis gunnellus

Pomatomus saltatrix

Hemitripterus americanus

as Raia

as Tautogolabrus adspersus

as Isuropsis dekayi

as Cyclopterus lumpus

as Murænoides mucronatus

as Pomatomus saltatrix

as Hemitripterus acadianus 
Fundulus heteroclitus

Fundulus beteroclitus

Fundulus heteroclitus

Myoxocephalus æneus

Myoxocephalus

octodecimspinosus

Lophopsetta maculata

Paralichthys dentata

Menidia menidia notata

Apeltes quadracus

Gasterosteus aculeatus

Anguilla rostrata

Gadus callarias

Sebastes marinus

Osmerus mordax

Ulvaria subbifurcata

Raia diaphanes (?)

Melanogrammus xeglifinnus

Merluccius bilinearis

Urophycis tenuis

Mierogadus tomeod

Lophopsetta maculata

Liopsetta putnami

Limanda ferruginea

Myoxocephalus grœenlandicus as Cottus grœnlandicus

Scomber scombrus

Alosa sapidissima as Fundulus pisculentus

as Fundulus heteroclitus

as Hydrargyra majalis

as Cottus mitchilli

as Cottus octodecimspinosus

as Lophopsetta maculata

as Pomatopsetta dentata

as Chirostoma notata

as Apeltes quadracus

as Gasterosteus biaculeatus

as Anguilla bostoniensis

as Gadus morrhua

as Sebastes norwegicus

as Osmerus mordax

as Eumesogrammus

subbifurcatus

as Raia eglanteria (ocellata)

as Melanogrammus itglitimnis

as Merlucius bilinearis

as Phycis tenuis

as Microgadus tomeod

as Liopsetta maculata

as Pleuronectes glaber

as Myzopsetta ferruginea (?)

as Scomber scombrus

as Alosa sapidissima

\section{8\%3a. U. S. National Museum.}

A salmon (Salmo sebago) collected by A. H. Leonard at Sebec Lake, Me., October 24, 1873, is recorded here as Salmo sebago.

Record Books of the Department of Fishes, U. S. N. M., Vol. III. 
18\%3b. U. S. National Museum.

Salvelimus oquassa, recorded here as Salmo oruassa, collected by "Sen. Edmonds, and E. G. Blackford". No dates given but probably about 1873 .

Record Books of the Department of Fishes, U. S. N. M., Vol. III.

1874. Stilwell, E. M., and Stanlex, Hexry O.

Seventh Report of the Commissioners of Fisheries of the State of Maine for the year 1873 (1874).

Cited as Me. F. C. Report, 1874.

List of species :

Salmo salar

as Salmon

Oncorhynchus tschawytscha as Salmo quinnat

Alosa sapidissima as Shad

Pomolobus pseudoharengus as Alewife

1874A. Stilwell, E. M., and Stanley, Henry O.

Eighth Report of the Commissioners of Fisheries of the State of Maine for the year 1874 (1874).

Also contains report on Bucksport salmon breeding works, by C. G. Atkins.

Cited as Me. F. C. Report, 1874A.

List of species :

Salmo salar

as Salmon

Salmo sebago

as Landlocked salmon

Salvelinus oquassa

as Salmo oquassa

18\%46. U. S. National Museum.

A smelt (Osmerus) collected at Industry, Me., March 31, 1874 , is perhaps referable to Osmerus spectrum.

Record Books of the Department of Fishes, U. S. N. M., Vol. III. 
18\%46. U. S. National Museum.

A lake trout (Salvelinus namaycush) collected by E. M. Stilwell is recorded as Salmo toma. The date is uncertain, but it was probably about 1874 .

Record Books of the Department of Fishes, U. S. N. M., Vol. III.

1875. [Boardman, Samuel L., and Atrins, Charles G.]

The Menhaden and Herring Fisheries of Maine in Connection with Agriculture.

Maine Board of Agriculture, 1875, with plate, pp. 1-64.

List of species :

Brevoortia tyrannus

Merluccius bilinearis

Pollachius virens

Thunnus thynnus

Pomatomus saltatrix

Clupea harengus

Sebastes marinus

as Brevoortia menhaden

as Merlucius bilinearis

as Pollachius carbonarius

as Orcynnus secundo-dorsalis

as Pomotomus saltatrix

as Clupea elongata

as Sebastes

1875. Goode, G. Brown.

Albino Fishes.

American Naturalist, Vol. IX, p. 517.

Mention of Gadus callarias as the rosy "rock-cod" of the coast of Maine, and its environment.

1875. Stillwell, E. M., and Stanley, Henry O.

Ninth Report of the Commissioners of Fisheries of the State of Maine for the year 1875 (1875).

Cited as Me. F. C. Report, 1875.

List of species:

Salmo salar

as Salmon

Salmo sebago

as Fresh water salmon

Micropterus dolomieu

as Black bass 
Salvelinus oquassa

Salvelinus namaycush

Coregonus labradoricus

Salvelinus fontinalis as Salmo oquossa

as Togue

as Whitefish

as Trout

\section{8\%5. U. S. Nitional Muserm.}

The nurse shark (Sommiosus microcepluchus) is recorded from Lastport, Me., in 1875.

Record Books of the Department of Fishes, U. S. N. M., Vol. IV.

\section{8\%5. U. S. National Museum.}

A salmon (Salmo sebayo) collected by Jos. R. Dillingham and Sumner Plummer in Sebago Lake, Raymond, Me., December 10, 1875, is recorded as Salmo gloveri.

Record Books of the Department of Fishes, U. S. N. M., Vol. III.

\section{8\%,b. U. S. National Museum.}

A smelt collected at Belgrade Mills, Me., by H. W. Golder, February 27, 1875, is recorded as Osmerus mordax.

Record Books of the Department of Fishes, U. S. N. M., Vol. III.

1876. Stilwell, E. M., and Stanlex, Hexry O.

Tenth Report of the Commissioners of Fisheries of the State of Maine for the year 1876 (1876).

Cited as Me. F. C. Report, 1876.

List of species:

Salmo salar

Salmo sebago

Micropterus dolomieu

Salmo salar

Salmo sebago as Salmon

as Salmo sebago

as Black bass

as Penobscot salmon

as Schoodic salmon 
1877. Eaton, Crrus, A. M.

Annals of the Town of Warren, in Knox County, Me., with the Early History of St. George's, Broad Bay, and the neighboring settlements on the Waldo Patent.

Second edition, Masters \& Livermore, Hallowell.

The matter relating to fishes is apparently similar to that contained in the first edition (see 1851). The table of vernal progress is brought up to 1876 .

1877. Stilwell, E. M., and Stanlex, Henri O.

Eleventh Report of the Commissioners of Fisheries of the State of Maine for 1877 (1877).

Cited as Me. F. C. Report, 1877.

List of species:

Salmo salar

as Salmon

Salmo sebago

as Salmo gloveri'or

Salmo sebago

Micropterus dolomieu as Black bass

\section{8\%\%. U. S. National Museum.}

Fishes from Grand Lake Stream, Maine, collected by the U. S. Fish Commission in 1877.

Record Books of the Department of Fishes, U. S. N. M., Vol. IV.

List of species:

Salmo sebago

Anguilla rostrati

Coregonus litbradoricus

Morone americana

Semotilus bullaris

Eupomotus gibbosus

Catostomus commersonii as Salmo sebago

as Anguilla bostoniensis

as Coregonus

as Morone americana

as Semotillus bullaris

as Eupomotis aureus

as Catostomus commersonii 
18\%7a. U. S. National Museum.

Fishes from Gulf of Maine, collected by U. S. Fish Commission in 1877.

Record Books of the Department of Fishes, U. S. N. M., Vol. IV (?)

List of species:

Leptoclinus maculatus as Leptoclinus aculeatus

Limanda ferruginea as Limanda ferruginea

1878. Athins, Charles G.

On the Collection of Eggs of Schoodic Salmon in 1875 and 1876.

Report U. S. Fish Commission, 1875-1876 (1878), pp. $910-919$.

List of species :

Salmo sebago

as Salmo sebago

Salmo sebago

as Salmo gloveri

Salmo salar

as Salmo salar

Salvelinus fontinalis

as Salmo fontinalis

Salvelinus namaycush

as Salmo tomit

Osmerus mordax

as Smelt

Anguilla rostrata

as Eel

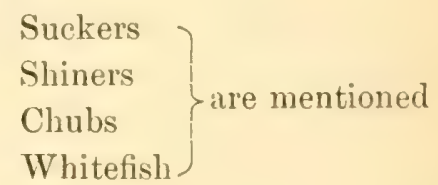

1878. MADDOCKS, LUTHER.

The Menhaden Fishery of Maine with Statistical and Historical Details, its Relations to Agriculture and as a Direct Source of Human Food, New Processes, Products and Discoveries. 
Report of the Secretary of the Association of the Menhaden Oil and Guano Manufactures of Maine, pp. 1-48, 1878 .

[Brevoortiu tyrannus as Clupea Menhaden, and Thumms thynnus as Abicore.]

1878. Stiliveli, E. M., and Stanley, Henry O.

Trvelfth Report of the Commissioners of Fisheries of the State of Maine for the year 1878 (1878).

Cited as Me. F. C. Report, 1878.

List of species:

Salvelinus oquassa

Notropis cornutus

Salino sebago

Salvelinus fontinalis

Salvelinus namaycush

Lota maculosa

Micropterus dolomieu

Pomolobus pseudoharengus as Alewife

\author{
as Salmo Oquossa \\ as Small redfin \\ as Landlocked salmon \\ as Brook trout \\ as Togue \\ as Cusk \\ as Black bass
}

18\%8. U. S. National Museum.

Fishes from Bucksport, Maine, collected by U. S. Fish Commission in 1878.

Record Books of the Department of Fishes, U. S. N. M., Vols. IV and V.

List of species :

Pseudopleuronectes

americanus as Pseudopleuronectes americanus

Liopsetta putnami as Pleuronectes glaber Myoxocephalus grœnlandicus as Cottus groenlandicus Hemitripterus americanus as Hemitripterus acadianus Zoarces anguillaris as Zoarces anguillaris Cyclopterus lumpus Osmerus mordax as Cyclopterus lumpus as Osmerus mordax 
Microgadus tomeod

Clupea harengus

Myoxocephalus

octodecimspinosus

Petromyzon marinus

Pomolobus pseudoharengus

Pomolobus restivalis as Microgadus tomeod

as Clupea harengus

as Cottus octodecimspinosus

as Petromyzon americanus

as Pomolobus vernalis

as Pomolobus restivalis

\section{WASSON, SAMUEL.}

Survey of Hancock County.

Annual Reports Agricultural Societies of Maine for $1877-$ 1878. Bound with Twenty-second Annual Report of the Naine Board of Agriculture for 1877, separately titled and paged. Fisheries at pp. 220-225.

List of species:

Gadus callarias

as Cod

Pollachius virens

as Pollack

Urophycis tenuis and chuss (?)

as Hake

Scomber scombrus

Clupea harengus

Brevoortia tyrannus

Osmerus mordax

Anguilla rostrata

Microgadus tomeod

Pseudopleuronectes

americanus

Pomolobus pseudoharengus

Salmo salar

Alosa sapidissima as Mackerel

as Herring

as Porgie

as Smelt

as Eel

as Frostfish

as Flounder

as Alewife

as Salmon

as Shad

\section{Beas, Tarleton $H$.}

On the Identity of Euchalarodus putnami, Gill, with Plenronectes yluber (Storer), Gill, with notes on the habits of the species. 
Proceedings U. S. National Museum, 1878, Vol. I, pp. 345348.

List of species:

Liopsetta putnami

as Pleuronectes glaber

Pseudopleuronectes

americanus as Pseudopleuronectes americanus

1879. Goode, G. Brown, and Bean, Tarleton H.

A list of the Fishes of Essex County, Mass.

Bulletin Essex Institute, 1879, Vol. XI, pp. 2-38.

List of species:

Myoxocephalus scorpius

Anarhichas minor

Lycenchelys verrillii

Scomberomorus maculatus

Scomberesox saurus

Raia diaphanes as Cottus scorpius

as Anarrhichas minor

as Lycodes Verrillii

as Cybium maculatum

as Scomberesox saurus

as Raia ocellata

1879. Goode, G. Brown.

The Natural and Economical History of the American Menhaden.

Report U. S. Fish Commission, 1876-1877, pp. 1-529. [Brevoortia tyrannus.]

1879. Stilwell, E. M., and Sinth, Everett.

Report of the Commissioner [s] of Fisheries of the State of Maine for the year 1879 .

Cited as Me. F. C. Report, 1879.

List of species:

Salmo salar

Osmerus mordax

Salvelinus fontinalis

Salmo sebago

Pomolobus pseudoharengus as Salmon

as Smelt

as Trout

as Landlocked salmon

as Alewife 
18\%9. T. S. National Museum.

A butterfish (Poronotus triacanthus) collected off Seguin, Maine, 50 fathoms, by Charles Buckley.

Record books of the Department of Fishes, U. S. N. M., Vol. V.

18\%91. U. S. National Museum.

Whitefish (Coregonus labradoricus) collected at Moosehead Lake, Maine, by E. G. Blackford, 1879.

Record books of the Department of Fishes, U. S. N. M., Vol. V.

1880. Atkins, Charles G.

Report on an Attempt to Collect Eggs of Sebago Salmon in 1878.

Report U.S. Fish Commision, 1878 (1880), pp. 775-787.

List of species:

Salmo sebago

Salvelinus fontinalis

Catostomus commersonii

Anguilla rostrata as Salmo sebago

as Salmo fontinalis

as Suckers

as Eel

1880. BAIRD, SPENCER F.

Report of the Commissioner.

Report U. S. Fish Commission, 1878, pp. xviii-xxxv. [Salmo salar as Salmo salar and Salmo sebago as Salmo salar. Sebago.]

1880. Bean, TARleton H.

Description of an Apparently New Species of Gasterosteus (G. Atkinsii), from the Schoodic Lakes, Maine.

Proceedings U. S. National Museum, 1879, Vol. II, pp. 67-69. 
1880. Kendall, W. C.

Collection made at Sabattus Pond, summer of 1880.

List of species :

Ameiurus nebulosus, Salvelinus fontinalis, Lepomis gibbosus.

1880. LEE, L. A.

Occurrence of the Web-fingered Sea Robin [Prionotus carolinus] on the coast of Maine.

American Naturalist, Vol. XIV, p. 896 (December, 1880).

1880. Stilwell, E. M., and Sinth, Everett.

Report of the Commissioners of Fisheries and Game of the State of Maine, 1880 (1880.)

Cited as Me. F. C. Report, 1880.

List of species:

Salmo salar

as Salmon

Salvelinus fontinalis

as Trout

Coregonus elupeformis

as Michigan whitefish

Pomolobus

Alosa sapidissima as Alewife

Petromyzon marinus

as Shad

Anguilla rostrata

as Lamprey

as Eel

Salmo irridea*

Osmerus mordax

as California trout

as Smelt

Lota maculosa

as Cusk or ling

1880. U. S. National Museum.

Miscellaneous records.

Record Books of the Department of Fishes, U.S. N. M., Vol. VI.

List of species:

Salmo sebago

Lepomis auritus as Salmo salar

as Ichthelis appendix

-Introduced. 
1881. Bean, TARLeton H.

Check-list of Duplicates of North American Fishes, distributed by the Smithsonian Institution in behalf of the United States National Museum, 1877-1880.

Proceedings U. S. National Museum, 1880, Vol. III, pp. $75-116$.

List of species :

Liopsetta putnami

Lophopsetta maculata

Pollachius virens

Microgadus tomeod

Urophycis tenuis

Merluccius bilinearis

\%oarces anguillaris

Pholis gunnellus

Myoxocephalus octodecimspinosus

Myoxocephalus scorpius

Hemitripterus americanus

Sebastes marinus

'Tautogolabrus adspersus

Scomber scombrus

Poronotus triacanthus

Menidia menidia notata

Osmerus mordax

Salmo sebago

Alosa sapidissima

Pomolobus pseudoharengus

Squalus acanthias

Clupea harengus

Anguilla rostrata as Pleuronectes glaber

as Lophopsetta maculata

as Pollachius carbonarius

as Microgadus tomcodus

as Phycis tenuis

as Merlncius bilinearis

as \%oarces anguillaris

as Murrenoides gunnellus

as Cottus octodecimspinosus

as Cottus scorpius

as Hemitripterus americanus

as Sebastes marinus

as Tautogolabrus adspersus

as Scomber scombrus

as Poronotus triacanthus

as Chirostoma menidium

as Osmerus mordax

as Salmo salar sebago

as Alosa sapidissima

as Pomolobus pseudoharengus

as Squalus acanthias

as Clupea harengus

as Anguilla rostrata

1889 and 1883. Benner, Captain.

While purse-seining mackerel, caught a lot of this species (Prionotus carolinus) off Monhegan Island, 1882 and 1883. 


\section{Stanley, Henry O.}

Report of the Commissioner of Fisheries and Game of the State of Maine for the year 1881 (1882).

Cited as Me. F. C. Report, 1882.

List of species:

Salmo salar

Alosa sapidissima

Micropterus dolomieu

Pomolobus pseudoharengus

Coregonus as Salmon

as Shad

as Black Bass

as Alewife

as Whitefish

\section{2a. Stanley, Henry O.}

Report of the Commissioner of Inland Fisheries and Game of the State of Maine, 1882 (1882).

Cited as Me. F. C. Report, 1882A.

List of species:

Salmo salar

Salmo sebago as Salmon

as Landlocked salmon

1883. Harsa, S. IV.

Description of an Eel-like Creature taken in a Net at New Harbor, Maine, in 1880.

Bulletin U. S. Fish Commission, 1883, Vol. III, pp. 407409.

[The animal described is doubtfully referred to as Chlamydoselacus anguineus.]

1889. Rendall, W. C.

S'motilus bullaris and Esox reticulatus were collected by . W. C. Kendall in Umbagog Lake in 1883. 
1883. Stilwelil, E. M., and Stanley, Henri O.

Report of the Commissioners of Fisheries and Game of the State of Maine for the year 1883 (1883).

Cited as Me. F. C. Report, 1883.

List of species:

Salmo salar

as Salmon

Salmo sebago

as Landlocked salmon

Micropterus dolomieu as Black bass

1853. U.S. National Muserm.

Fishes from Auburn, Maine, collected by G. P. Merrill in August, 1883.

Record Books of the Department of Fishes, U. S. N. M., Irol. VII.

List of species:

Ameiurus nebulosus

as Ameiurus nebulosus

Perca flavescens

as Perca americana

Lepomis gibbosus

Cottus gracilis

Rhinichthys atronasus

Semotilus bullaris

Abramis crysoleucas

Chrosomus erythrogaster

Semotilus atromaculatus

as Lepomis gibbosus

as Uranidea gracilis

as Rhinichthys atronasus

as Semotilus bullaris

as Notemigonus chrysoleucas

as Chrosomus erythrogaster

as Semotilus corporalis

1884. Atrins, Charles G.

Memoranda Relative to Inclosures for the Confinement of Salmon [Salmo salar] Drawn from Experience at Bucksport, Penobscot River, Maine.

Bulletin U.S. Fish Commission, 1884 (1884), Vol. IV, pp. $170-17 t$.

1884a. Atmins, Charles G.

Memoranda on Landlocked Salmon. 
Bulletin U.S. Fish Commission, 1884, Vol IV, .pp. $341-344$ [Salmo sebago].

1884в. Atisins, Charles G.

Ten Questions Concerning the Habits of and Breeding of Landlocked Salmon, with Replies.

Bulletin U. S. Fish Commission, 1884 (1884), Vol. IV, pp. 383, 384. [Salmo sebago.]

1884c. AtKins, Chaliles G.

Notes on Landlocked Salmon.

Transactions of the American Fish-Cultural Association, 1884, pp. 40-54. [Salmo sebago.]

1884. Goode, G. Brown.

Fisheries and Fishery Industries of the United States, Section I, Text, 1884.

List of species:

Lophius piscatorius

Pseudopleuronectes

americanus as Pseudopleuronectes americanus

Lophopsetta maculata

as Rhombus maximus

Hippoglossus hippoglossus

Gadus callarias

as Hippoglossus vulgaris

as Gadus morrhua

Melanogrammus æeglefinus

as Melanogrammus rglefinus

Pollachius virens

as Pollachius carbonarius

Brosmius brosme

as Brosmius brosme

Urophycis

Lota maculosa

as Hake, Phycis chuss, ete.

as Lota maculosa

Koarces anguillaris

Anarhichas lupus

Myoxocephalus

as Zoarces anguillaris

as Anarrhicas lupus

octodecemspinosus as Cottus octodecemspinosus

Sebastes marinus as Sebastes marinus 
Tautogolabrus adspersus

Scomber scombrus

Scomberomorus maculatus

Poronotus triacan thus

Xiphias gladius

Lepomis gibbosus

Lepomis auritus

Pomatomus saltatrix

Salmo salar

Salvelinus namayeush

Salvelinus fontinalis

Salvelinus oquassa

Osmerus mordax

Clupea harengus

Brevoortia tyrannus

Pomolobus pseudoharengus

Alosa sapidissima

Pomolobus mediocris

Erimyzon oblongus

Cetorhinus maximus

Careharodon carcharias

Squalus acanthias as Ctenolabrus adspersus as Scomber scombrus as Scomberomorus maculatus as Stromateus triacanthus as Xiphias gladius as Lepomis gibbosus as Lepomis auritus as Pomatomus saltatrix* as Salmo salar as Salvelinus namaycush as Salvelinus fontinalis as Bluebacked or Oquassa trout as Osmerus mordax as Clupea harengus as Brevoortia tyrannus as Pomolobus pseudoharengus as Clupea sapidissima as Clupea mediocris as Erimyzon sucetta as Cetorhinus maximus as Carcharodon carcharias as Squalus acanthias

1884. Goode, G. Brown, Colduns, Joseph W., Ealill, R. E., and Clark, A. Howard.

Material for a History of the Mackerel Fishery.

Report U. S. Fish Commission, 1881 (1884), pp. 91-531. [Scomber scombrus.]

1884. Jordan, David S., and Gilbert, Charles H. A Review of the American Carangine.

Proceedings U. S. National Museum, 1883, Vol. VI, pp. 188-207. [Vomer setapinnis as Curenx setipinnis.]

'Cited on the authority of Josselyn, $16 \imath^{2}$. 
1884. Page, George Shephard.

Black Bass in Maine.

Transactions of American Fish-cultural Association. Thirteenth Annual Meeting, 1884, pp. 57-60. [Micropterus rolomier.]

1884. Stilweld, E. M., and Stanley, Henry O.

Report of the Commissioners of Fisheries and Game of the State of Maine for the year 1884 (1884).

Cited as Me. F. C. Report, 1884.

List of species :

Salmo salar

Salmo sebago

Salvelinus fontinalis

Coregonus

Pomolobus pseudoharengus

Brevoortia tyrannus as Salmon

as Landlocked salmon

as Trout

as Whitefish

as Alewife

as Porgie

\section{U. S. National Museum.}

Miscellaneous records.

Record Books of the Department of Fishes, U. S. N. M., Vol. VI.

List of species :

Salvelinus oq uassa

Salmo sebago

Salvelinus fontinalis as Salvelinus oquassa as Salmo salar sebago as Salvelinus fontinalis

1885. Lee, Leslie A.

The Fishes of Casco Bay.

Read before Portland Society of Natural History.

Portland Advertiser, March 3, 1885, and Brunswick Telegraph, Friday, March 13, 1885. 


\begin{tabular}{|c|c|}
\hline XOMINAT, SPECIES. & IIDENTIFICATION. \\
\hline 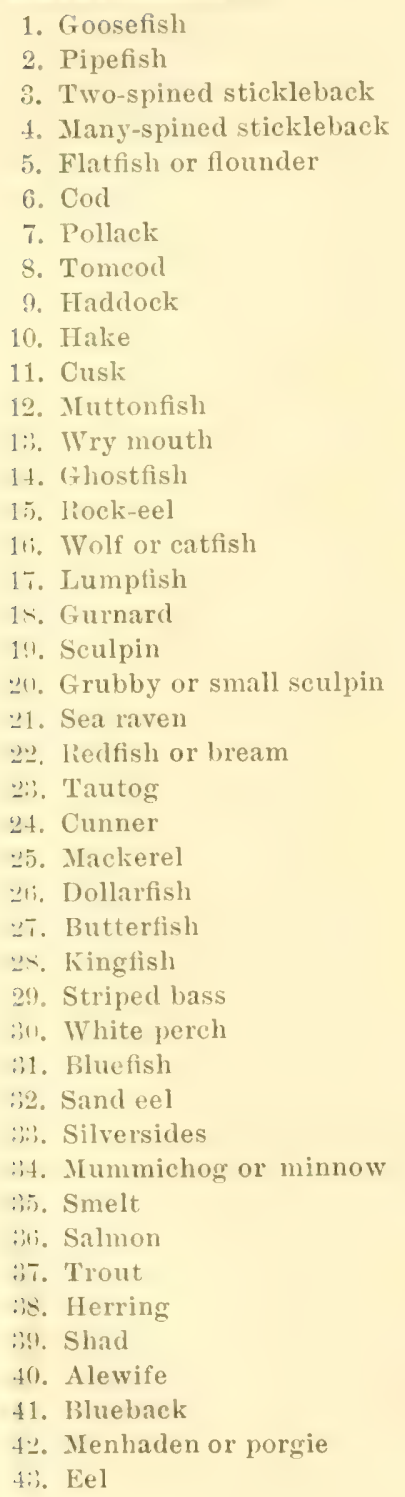 & $\begin{array}{l}\text { Lophius piscatorius } \\
\text { Siphostoma fuscum } \\
\text { Gasterosteus aculeatus } \\
\text { Pungitius pungitius } \\
\text { Pseudopleuronectes americanus } \\
\text { Gadus callarias } \\
\text { Pollachius virens } \\
\text { Microgadus tomeod } \\
\text { Melanogrammus rglefinus } \\
\text { Europhycis tenuis or chuss or both } \\
\text { Brosmius brosme } \\
\text { \%oarces anguillaris } \\
\text { Cryptacanthodes maculatus } \\
\text { Cryptacanthodes maculatus } \\
\text { Pholis gunnellus } \\
\text { Anarhichas lupus } \\
\text { Cyclopterus lumpus } \\
\text { Prionotus carolinus } \\
\text { Myoxocephalus octodecimspinosus } \\
\text { Myoxocephalus rneus } \\
\text { Hemitripterus americanus } \\
\text { Sebastes marinus } \\
\text { Tautoga onitis } \\
\text { Tautogolabrus adspersus } \\
\text { Scomber scombrus } \\
\text { Poronotus triacanthus } \\
\text { Pholis gunnellus } \\
\text { Menticirrhus saxatilis } \\
\text { Roccus lineatus } \\
\text { Morone americana } \\
\text { Pomotomus saltatrix } \\
\text { Ammodytes americanus } \\
\text { Menidia menidia notata } \\
\text { Fundulus heteroclitus } \\
\text { Osmerus mordax } \\
\text { Salmo salar } \\
\text { Salvelinus fontinalis } \\
\text { Clupea harengus } \\
\text { Alosa sapidissima } \\
\text { Pomolobus pseudoharengus } \\
\text { Pomolobus aestivalis } \\
\text { Brevoortia tyrranus } \\
\text { Anguilla rostrata }\end{array}$ \\
\hline
\end{tabular}



44. Sharp-nosed sturgeon
45. Skate
46. Spiny skate
47. Dusky shark
48. Dogfish
49. Lamprey eel

Acipenser sturio
Raia erinacea
Raia radiata
Carcharias littoralis
Squalus acanthias
Petromyzon marinus

1885. Mather, Fred.

Protecting and Hatching the Smelt.

Transactions of the American Fisheries Society, 1885, pp. $17-32$.

[Mentions "the big smelts", "little smelts", and "Osmems viridescens or saltwater smelt", making an article entitled, "Torching for Smelts", in Forest and Stream by "A gentleman from North Bridgton".]

1886. Counce, B. W.

Report of the Commissioner of Sea and Shore Fisheries of the State of Maine, 1886.

Cited as Me. S. and S. F. Report, 1886.

List of species:

Scomber scombrus

as Mackerel

Osmerus mordax as Smelt

Pomolobus pseudoharengus as Alewife

1886. Eigmanann, Carl H.

A Review of the American Gasterosteidie.

Proceedings Academy of Natural Sciences of Philadelphia, 1886, pp. 233-252. [Gusterosteus atkinsii.]

\section{Goold, Wildian.}

Portland in the Past, with Historical Notes of Old Falmouth.

Printed for the author by B. Thurston \& Company, Portland, Maine. 
Scattered notes on the extent, value and history of the early fisheries, particularly the sturgeon fishery, which was once of some importance in southwestern Maine.

1886. Stillwell, E. M., and Stranley, Henri O.

Report of the Commissioners of Fisheries and Game of the State of Maine for the year 1886 (1886).

Cited as Me. F. C. Report, 1886.

List of species:

Salmo salar

as Sea salmon

Salmo sebago as Landlocked salmon

Micropterus dolomieu as Black bass

1887. Аткия, C. ('.

The River Fisheries of Maine.

The Fisheries and Fishery Industries of the United States, 1887, Section V, Part I, pp. 673-728.

List of species:

Acipenser sturio

Anguilla rostrata

Clupea harengus

Pomolobus pseudoharengus

Pomolobus restivalis

Alosa sapidissima

Salmo salar

Osmerus mordax

Perea flavescens

Roccus lineatus

Microgarlus tomcod

Gadus callarias

as Acipenser sturio

as Anguilla rostrata

as Herring

as Clupea vernalis

as Blueback

as Clupea sapidissima

as Salmo salar

as Osmerus mordax

as Perch

as Roccus lineatus

as Tomeod

as Cod

1887. Collins, Joseph W., and Ratubun, Richard.

The Sea Fishing Grounds of the East Coast of North America from Greenland to Mexico. 
The Fisheries and Fishery Industries of the United States, 1887, Section. III, pp. 5-78.

List of species:

Urophycis tenuis

as Hake

Gadus callarias

as Cod, rock cod

Pollachius virens

Melanogrammus aglefinus as Pollack

Brosmius brosme as Haddock

as Cusk

Clupea harengus

as Herring

Scomber scombrus

as Mackerel

\section{8\%. U. S. National Museum.}

Fishes from Casco Bay, Maine, collected by Capt. Geo. Douglass, Schooner Constitution.

Record Books of the Department of Fishes, U. S. N. M., Vol. IX.

List of species:

Cyclopterus lumpus

Shipostoma fuscum

as Cyclopterus lumpus

Poronotus triacanthus as Siphostoma fuscum

Selene vomer as Stromateus triacanthus as Selene vomer

\section{Counce, B. W.}

Report of the Commissioner of Sea and Shore Fisheries of the State of Maine, 1888.

Cited as Me. S. and S. F. Report, 1888.

List of species:

Scomber. scombrus

Osmerus mordax

Brevoortia tyrannus

Pomolobus

Salmo salar

Clupea harengus (Young) as Mackerel

as Smelt

as Menhaden

as Alewife

as Sea salmon

as Sardine 
1888. Struwell, E. M., and Stanley, Henry O.

Report of the Commissioners of Fisheries and Game of the State of Maine for the year 1888 (1888).

Cited as Me. F. C. Report, 1888.

List of species :

Salmo salar

Salmo sebago

Misropterus dolomieu

Morone americana as Sea salmon

as Landlocked salmon

as Black bass

as White perch

1890. Hatch, Dr. William C.

A specimen of Coregonus quadritateralis from Clear-water Pond, Industry, Maine, April 9, 1890, was received from Dr. Hatch by the U. S. Fish Commission for identification.

1890. U. S. Fish Commission.

In the reserve series of the U. S. Fish Commission there is a very large specimen of a female pipefish (Siphostomu fuscum), sent from Eastport by Mr. C. W. Hume. No date is on the label, but it was probably about 1890. It is the largest specimen of pipefish we have ever seen on the Atlantic coast of the United States.

1891. Counce, B. W.

- Report of the Commissioner of Sea and Shore Fisheries of the State of Maine, 1889-1890 (1891).

Cited as Me. S. and S. F. Report, 1891.

List of species:

Scomber scombrus

Brevoortia tyrannus

Pomolobus

Osmerus mordax as Mackerel

as Menhaden

as Alewife

as Smelt 
1891. Stilwell, E. M., and Stanley, Henry O.

Report of the Commissioners of Fisheries and Game of the State of Maine, for the years 1889-1890 (1891).

Cited as Me. F. C. Report, 1891.

List of species:

Salmo salar

as Salmon

Salmo sebago

as Landlocked salmon

1892. Garman; S.

The Discoboli. Cyclopteridie, Liparapsidæe, and Liparidide, with 13 plates.

Memoirs of the Museum of Comparative Zoölogy, 1892, Vol. XIV, No. 2, pp. 1-96.

List of species:

Eumicrotremus spinosus

as Eumicrotremus spinosus

Neoliparis atlanticus

Liparis liparis

as Liparis montagui

as Liparis liparis

1892. Kendall, W. C.

During the summer of 1892, a small collection of the fishes of Casco Bay was made by W. C. Kendall, while making a special study of menhaden. The following species were taken :

Anguilla rostrata, Clupea harengus, Pomolobus pseudoharenyus, Pomolobus cestivalis, Alosa sapidissima, Brevoortia tyrannus, Fundulus heteroclitus, Menidiu menidia notata, Scomber scombrus, T'autogolabrus adspersus, Myoxocephahus scorpius, Myoxocephalus græentandicus, Myoxoceptulus octodecimspinosus, Pholis gunnellus, Pollachius virens, Gadus callarias, Pseudopleuronectes americanus, Liopsetta putnami.

\section{GodLd, EdWIN W.}

[Report of the Commissioner of Sea and Shore Fisheries for the years 1891-1892, pp. (17)-44 in,] 
Report of the Commissioners of Fisheries and Game of the State of Maine for the years 1891-1892 (1892).

Cited as Me. S. and S. F. Report, 1892.

List of species :

Scomber scombrus

Brevoortia tyrannus

Roceus lineatus

Alosa sapidissima as Mackerel

as Menhaden

as Roceus lineatus

as Shad

1892. Stilwell, E. M., and Stayley, Hexry O.

Report of the Commissioners of Fisheries and Game of the State of Maine for the years 1891-1892 (1892).

Cited as Me. F. C. Report, 1892.

List of species:

Salmo salar

as Sea salmon

Salmo sebago

as Landlocked salmon

1892. U. S. National Museum.

Record Books of the Department of Fishes, U. S. N. M., Vol. IX.

[Fundulus heteroclitus.]

1893. Kendall, W. C.

Collections made at Eastport, Maine, Summer of 1893.

List of species:

Myxine glutinosa, Alopias vulpes, Clupea harengus, Pseudopleuronectes americamus, Pomolobus pseudoharengus, Pomolotus astivalis, Alosa sapidissima, Salmo salar (Denny's River), Osmerus mordax, Fundulus heteroclitus, Gasterosteus aculeatus, Menidia menidia notata, Ammodytes americanus, Thunnus thynmus, Sebastes marinus, Myoxocephalus octodecimspinosus, Myoxocephalus scorpius, Myoxocephalus gronlandicus, Hemitripterus americams, Aspidophoroides monopterygius, Cyclopterus lumpus, Pholis gunnellus, Cryptacanthodes maculatus, Anarhichas 
lupus, Zoarces anguillaris, Merluccius bilinearis, Pollachius virens, Microgadus tomcod, Gadus callarias, Melanogrammus aglefinus, Urophycis tenuis, Urophycis chuss, Enchelyopus cimbrius (at Jonesport), Brosmius brosme, Macrourus bairdi, Pseudopleuronectes americanus, Lophius piscatorius.

1894. Kendall, W. C.

Notes on the Fresh-water Fishes of Washington County, Maine.

Bulletin U. S. Fish Commission, $189 \pm$ (1895), Vol. XIV, pp. $43-54$.

List of species:

Catostomus commersonii

as Catostomus teres

Notropis cornutus

Semotilus bullaris

Fundulus diaphanus

Anguilla rostrata

Lepomis gibbosus

Perca flavescens

Abramis crysoleucas

Osmerus mordax

Esox reticulatus

Micropterus dolomieu

Rhinichthys atronasus

Pomolobus restivalis

Salmo salar

Salmo sebago

Salvelinus fontinalis

Pungitius pungitius

Ameiurus nebulosus

Salvelinus namayeush

Coregonus labradoricus

Morone americana

as Notropis megalops

as Semotilus bullaris

as Fundulus diaphanus

as Anguilla chrysypa

as Lepomis gibbosus

as Perca flavescens

as Notemigonus chrysoleucas

as Osmerus mordax

as Lucius reticulatus

as Micropterus dolomieu

as Rhinichthys atronasus

as Clupea restivalis

as Salmo salar

as Salmo salar sebago

as Salvelinus fontinalis

as Pygosteus pungitius

as Ameiurus nebulosus

as Togue

as Whitefish

as White perch 
1894. Kendall, IV. C., and Simth, Hugh M.

Extension of the Recorded Range of Certain Marine and Fresh-water Fishes of the Atlantic Coast of the United States.

Bulletin U. S. Fish Commission, 1894 (1895), Vol. XIV, pp. 15-21.

List of species:

Chrosomus erythrogaster

Couesius plumbeus

Semotilus atromaculatus

Fundulus diaphanus

Salvelinus fontinalis

Catostomus commersonii

Notropis cornutus

as Catostomus teres

as Notropis megalops

Rhinichthys atronasus

Semotilus bullaris

Pungitius pungitius

as Pygosteus pungitius

1894. Wextworth, Thomas H., and Stanley, Henry O.

Report of the Commissioners of Inland Fisheries and Game of the State of Maine for the years 1893-1894 (1894).

Cited as Me. F. C. Report, 1894.

List of species :

Salmo sebago

Salvelinus fontinalis

as Landlocked salmon

Salmo salar

as 'Trout

as Sea salmon

1894. Whittex, Orin B.

[Report of the Commissioner of Sea and Shore Fisheries for the years 1893-1894, pp. (29)-38 in,]

Report of the Commissioners of Fisheries and Game of the State of Maine for the years 1893-1894 (1894).

Cited as Me. S. and S. F. Report, 1894. 
List of species:

Clupea harengus

Scombèr scombrus

Osmerus mordax

Brevoortia tyrannus as Herring

as Mackerel

as Simelt

as Menhaden

1895. НАтсн, G. M.

Big Fish in Franklin County.

Maine Sportsman, 1895, Vol. II, August 7. [Salvelimus namaycush as Salmo namaycush.]

1895a. Kendall, W. C:

A small collection of fishes made in Chickawaka Lake and tributaries, Rockland, August 24, 1895, is referred to in the catalogue as Kíndall Coll., 1895a.

List of species:

Misropterus dolomien, Lepomis gibbosus, Fundulus diaphanus, Apeltes quadracus, Rhinichthys atronasus, Anguillu rostrata, Esox reticulatus, Catostomus commersonii, Abramis crysoleucas, Notropis cornutus.

\section{5b. Keridall, W. C.}

A collection of marine fishes made off the coast of Maine, while the writer was serving as naturalist of the U. S. Fish Commission, Schooner Grampus, summer of 1895, is mentioned in the catalogue as Kendall Coll., 1895b.

List of species:

Gasterosteus aculeatus, Gasterosteus bispinosus, Cyclopterus lumpus, Gadus callarias, Scomber scombrus, Scomber colias, Pomolobus mediocris, Pomolobus pseudoharenyus, Pomolobus cestivalis, Alos! sapidissima, Siphostoma fuscum, Urophycis cluss or tenuis, Tulpecula marina, Isurus punctatus. 
1895. Shrgent, H. IV.

Big Fish at Schoodic.

Maine Sportsman, 1895, Vol. II, p. 1.

[Salvetinus namayeush as togue.]

1896a. Carletor, Leroy T., Stanley, Hexry O., and OAK, CHARLES L.

Report of the Commissioners of Inland Fisheries and Game for the State of Maine for the year 1896 (1896).

Cited as Me. F. C. Report, 1896A. See 1896. Wentworth et als.

List of species:

Salmo sebago

as Salmon

Salvelinus fontinalis

as Trout

Salmo gairdneri

as Steelhead trout

Salmo salar

as Atlantic salmon

Salmo sebago

as Landlocked salmon

Salmo fario*

Morone americana

as Brown trout

Micropterus dolomieu as IVhite perch

as Black bass

1896. Evermans, Barton W., and Simth, Hugh M. The Whitefishes of North Anerica.

Report U. S. Fish Commission, 1894 (1896), pp. 283324. [Coregonus labradoricus and Coregonus quadrilateratis.]

1896. Goode, George Browy, and Bean, Tarleton H.

Oceanic Ichthyology, A Treatise on the Deep-sea and Pelagic Fishes of the IVorld, based chiefly upon the collections made by the Steamers Blake, Albatross and Fish Hawk in the Northwestern Atlantic, with an Atlas containing 417 figures (1895).

"Introduced. 
List of species :

Chlumydoselachus anyuineus (?), Cetorhinus maximus, Anarhichas minor, Glyptocephalus cynoglossus, Argentina silus.

1896. Jordan, David Starr, and Evermann, BarTON WARREN.

The Fishes of North and Middle America [four parts].

Bulletin 47, U. S. National Iuseum, 1896, Part I, pp. 1-1240.

List of species :

A meiurus nebulosus

Chrosomus erythrogaster

Semotilus atromaculatus

Anguilla rostrata

Clupea harengus

Salmo sebago

Salvelinus aureolus

Salvelinus oquassa

Osmerus spectrum

Osmerus abbottii

Argentina silus

Fundulus heteroclitus

Gasterosteus atkinsii

Apeltes quadracus

Scomber colias

Vomer setapinnis

Lampris luna

Poronotus triacanthus

Lepomis auritus

Lepomis gibbosus

as Ameiurus nebulosus

as Chrosomus erythrogaster

as Semotilus atromaculatus

as Anguilla chrysypa

as Clupea harengus

as Salmo salar sebago

as Salvelinus alpinus aureolus

as Salvelinus oquassa

as Osmerus mordax spectrum

as Osmerus mordax abbotti

as Argentina silus

as Fundulus heteroclitus

as Gasterosteus bispinosus

atkinsii

as Apeltes quadracus

as Scomber colias

as Vomer setipinnis

as Lampris luna

as Rhombus triacanthus

as Lepomis auritus

as Eupomotis gibbosus 
1896. Kendall, W. C.

Collections made at Small Point, Casco Bay, from June 23 to July 15, at Rockland and Vinal Haven, July 22, and off Monhegan Island, August 17, 1896, by W. C. Kendall, while serving as naturalist on board the U. S. Fish Commission Schooner Grampus.

List of species :

Petromyzon marimes, Curcharias turus, Raia erinacea, Raia diaphanes, Narcacion nobitians, Acipenser sturio, C'lupea havengus, Pomolobus mediocris, Pomolobus pseudoharengus, Pomolobus astivatis, Alosa supidissima, Brevoortiu tyramm, Salmo salar, Osmerus mordux, Scomberesox saurus, Ammodytes americamus, Scomber scombrus, Scomber colias, Pomatomus saltatrix, Poronotus triacunthus, Roccus lineatus, Centropristes striutus, Stenotomus chrysops, Tautogolabrus adspersus, Tautoga onitis, Spheroides maculatus, Myoxocephalus octodecimspinosus, Hemitripterus americanus, Cyclopterus lumpus, Zoarces anguillaris, Prionotus carolimus, Merluccius bitinearis, Pollachius virens, Gudus callarias, Melanogrammus ceplefinus, Urophycis tenuis, Urophycis chuss, Lophopisettu maculutu, Pseudoplenronectes americans, Lophius piscatorius, Gasterostens aculeatus, Gusterosteus bispinosus.

1896. Kendalt, IV. C.

Description of a New Stickleback, Gasterosteus gladiuncuhes, from the Coast of Maine.

Proceedings U. S. National Museum, 1895 (1896), Vol. XVIII, pp. 623,624 .

List of species:

Gasterosteus bispinosus

as Gasterosteus gladiunculus

(tyle)

Gasterosteus aculeatus

as Gasterosteus bispinosus

Urophycis chuss or tenuis as Phycis chuss or tenuis Siphostoma fuscum as Siphostoma fuscum 
1896. Wentworth, Thomas H., Stanley, Hexry O., and OAK, Charles E.

Repart of the Commissioners of Inland Fisheries and Game of the State of Maine for the year 1895 (1896).

Cited as Me. F. C. Report, 1896. See 1896A. Carleton et als.

List of species:

Salmo salar

Salmo sebago

Salvelinus fontinalis

Salmo fario*

Osmerus mordax as Atlantic salmon

as Landlocked salmon

as Brook tront

as Brown trout

as Smelt

1897A. Kíndald, Willian C.

Notes on the Food of Four Species of the Cod Family.

Report L. S. Fish Commission, 1896 (1897), pp. 177-186.

List of species:

Gadus callarias, Pollachius virens, Urophycis tenwis, Metanogrammus ceglefinus.

1897. MoORE, H. F.

Observations upon the Herring and Herring Fisheries of the Northeast Coast, with Special Reference to the Vicinity of Passamaquoddy Bay.

Report U. S. Fish Commission, 1896 (1897), pp. 387-442.

List of species:

Clupea harengus

Gadus callarias

as Clupea harengus

Melanogrammus reglefinus as $\mathrm{Cod}$

Pollachius virens

as Haddock

Urophycis tenuis

as Pollack

as Hake

Merluccius bilinearis

as Silver hake

Squalus acanthias

as Dogfish

Thunnus thynnus

as Albacore

*Introduced. 
1897. Rathiun, Richard, and IVAKehAi, Wv.

Preservation of the Fisheries in the IVaters Contiguous to the United States and Canada.

House of Representatives Document, 54th Congress, 2nd Session, 1897, pp. 1-178.

I ist of species:

Salmo salar

Pomolobus pseudoharengus

Salvelinus fontinalis

Salvelinus namaycush

Salmo sebago

Alosa sapidissima

Esox reticulatus

Morone americana

Catostomus commersonii

Coregonus labradoricus

Clupea harengus

Urophycis tenuis

Urophycis chuss

Pollachius virens

Melanogrammus reglefinus

Gadus callarias

Osmerus mordax as Salmo salar

as Pomolobus pseudoharengus

as Salvelinus fontinalis

as Cristivomer namaycush

as Salmo salar sebago

as Shad

as Lucius

as White perch

as Suckers

as Whitefish

as Clupea harengus

as Phycis tenuis

as Phycis chuss

as Pollachius virens

as Melanogrammus rglefinus

as Gadus callarias

as Osmerus mordax

\section{WhitTeN, OrIN B.}

Report of the Commissioner of Sea and Shore Fisheries of the State of Maine for the year 1896 (1897).

Cited as Me. S. and S. F. Report, 1897.

List of species:

Clupea harengus

Alosa sapidissima

as Herring

Brevoortia tyrannus

as Shad

Osmerus mordax

as Menhaden

as Smelt 
Śalmo salar

Pomolobus

Xiphiàs gladius

Anguilla rostrata

Acipenser sturio

Roccus lineatus

Mierogadus tomeod as Salmon

as Alewife

as Swordfish

as Eel

as Sturgeon

as Bass

as Tomeod

1898. Carleton, Leroy T., Stanlex, Hexry O., and OAK, Charles E.

Report of the Commissioners of Inland Fisheries and Game for the State of Maine for the year 1897 (1898).

Cited as Me. F. C. Report, 1898.

List of species:

Salmo sebago

Salvelinus aureolus

Oncorhynchus tschwytscha* as Landlocked salmon

as Golden trout

as Quinnat salmon

1898. Kendall, W. C'.

Collections of, in Sebago Lake and Neighboring Waters. List of species :

Ameiurus nebulosus, Catostomus commersonii, Erimyzon oblongus, Semotilus bullaris, Abramis crysolencas, Notropis bifrenatus, Notropis cormutus, Anguilla rostrata, Salmo sebayo, Salvelinus fontinalis, Osmerus mordax, Esox reticulatus, Lepomis gibbosus, Wicropterus dolomien, Perca flavescens, Morone mericana.

1898. Jordan, David Stari, and Everiany, BarTON WARREN.

The Fishes of North and Middle America.

Bulletin 47, U. S. National Museum, 1898, Part II, pp. 1241-2183. 
List of species :

Tantoga onitis, Sebastes marimus, Myoxocephulus scorpius, Eumicrotremus spinosus, Liparis liparis.

1898A. JOIDAN, DAYID STARR, and EvERMAYN, BARTOY IVAREN.

The Fishes of North and Middle America.

Bulletin 47, U. S. National Miseum, 18:9, Part III, pp. 218t-3136.

List of species :

Anarhichas minor, Lycenchelys verrillii, Lophopsetta maculata, Liopsetta putnami, Gasterosteus bispinosus as Gusterosteus gladiunculus.

1898. Merrilt, Elamer D.

Collection of, sent to U. S. National Museum. Designated here as Merrill Coll., 1898.

List of species:

Cutostomus catostomus, Fundulus diuphanus, Coussius plumbeus, Osmerus mordux (?), Osmerus abbottii, Lepomis auritus, Gasterosteus atkinsii.

1898. Nickelison, Alonzo R.

Report of the Commissioner of Sea and Shore Fisheries of the State of Maine, 1898 (1898).

Cited as Me. S. and S. F. Report, 1898.

List of species:

Clupea harengus

Brevoortia tyrannus

as Herring

Osmerus mordax

as Menhiden

Pomolobus pseudoharengus

as Sinelt

Roceus lineatus

as Alewife

Anguilla rostrata

as Bass

as Eel 
Pseudopleuronectes

americanus as Flounder

Scomber scombrus

as Mackerel

Salmo salar

as Salmon

Alosa sapidissima

as Shad

Xiphias gladius

as Swordfish

\section{Smith, Hugh M.}

The Salmon Fishery of Penobscot Bay and River in 1895 and 1896.

Bulletin U. S. Fish Commission, 1897 (1898), Vol. XVII, pp. 113-124. [Salmo salur as "salmon".]

1898. Simth, Hugh M., and Kexdali, Wilitam C.

Notes on the Extension of the Recorded Range of Certain Fishes of the United States Coast.

Report U.S. Fish Commission, 1896 (1898), pp. 169-176.

List of species:

Narcacion nobilianus

Lophopsetta maculata

Spheroides maculatus

Apeltes quadracus

Centropristes striatus

Stenotomus chrysops

Prionotus carolinus
as Tetronarce occidentalis
as Bothus maculatus
as Spheroides maculatus
as Apeltes quadracus
as Centropristes striatus
as Stenotomus chrysops
as Prionotus carolinus

1899. Carleton, leroy 'T., Stanley, Henry O., and Oat, Charles E.

Report of the Commissioners of Inland Fisheries and Game for the State of Maine for the year 1898 (1899).

Cited as Me. F. C. Report, 1899.

List of species:

Salvelinus fontinalis

as Trout

Oncorhynchus tschawytscha* as Quinnat salmon

*Introduced. 
Salmo salar

Morone americana

Micropterus dolomieu as Penobscot salmon as White perch as Black bass

1899. Kendall, W. C.

List of species collected in Sebago Lake and neighboring waters, 1899. One species, Couesius plumbeus, was added to the list of 1898 .

1899a. Kendall, W. C.

Collections of, made at Cobbosseecontee Lake and neighboring waters in 1899, referred to in the catalogue as Kendall Coll., 1899a.

List of species:

Ameiurus nebulosus, Catostomus commersonii, Chrosomus erythrogaster, Abramis crysoleucas, Semotilus bullaris, SemotiTus atromaculatus, Notropis cornutus, Rhinichthys atronasus, Salmo sebago, Salvelinus fontinalis, Fundulus diaphanus, Esox retioulatus, Eucalia inconstans, Gasterosteus atkinsii, Lepomis auritus, Lepomis gibbosus, Micropterus dolomieu, Perca flavescens, Morone americana.

1899. Merrill, Elmer D.

Notes furnished to W. C. Kiendall, 1899. Referred to here as Merrill Coll., 1899.

List of species:

Fundulus diaphanus, Alosa sapidissima, Ameiumes nebulosus, Catostomus commersonii, Semotilus bullaris, Chrosomus: erythrogaster, Abramis crysoleucas, Notropis comutus, Osmerus mordax (?), Osmerus abbottii, Lepomis gibbosus, Lepomis auritus, Couesius plumbeus, Petromyzon marimis, Salmo sebayo, Morone americana, Lote muculosa, Catostomus catostomus, Gasrost eus atkinsii, Rhinichthys atronasus. 
1900. Bowdoin College.

Collections of. In the collections in the Museum of Bowdoin are specimens from many parts of the State, collected by Prof. L. A. Lee, students and others. Dates of many of these collections are not given, but they run from the seventies up to date. During the fall of 1900 , Prof. Lee kindly allowed the writer to examine the specimens, and they are referred to in this paper as Bowdoin College Coll., 1900, followed by the actual date of the collection when known. The following are the names of some of the collectors: Prof. Leslie A. Lee, Mr. James Johnson, Dr. G. W. Knowlton, Mr. S. M. Preble, Mr. J. C. Mead, Mr. H. N. Whittier, Mr. O. A. Gilbert, Mr. Z. W. Kemp, Mr. W. W. Kilgore, Mr. WV. C. Kendall, and others whose names we were unable to ascertain.

List of species :

Petromyzon marinus, Isumes punctatus, Raiu erinacea, Ameiurus nebulosus, Semotilus bullaris, Semotilus atromaculatus, Catostomus commersonii, Cottus gracilis, Rhinichthys atronasus, Salvelinus oquassa, Gasterosteus aculeatus, Gasterosteus bispinosus, Cyclopterus lumpus, Urophycis temis, Prionotus carolimus, Salvelinus fontinalis, Coregonus quadrilateralis, Osmerus mordax, Fundulus heteroclitus, Fundulus diaphanus, Lepomis auritus, Sarda sarda, Neoliparis atlanticus, Pholis gumnellus, Scomberesox saurus, Selene vomer, Menticirrhus saxatilis, Pungitius pungitius, Pollachius virens, Morone americana, Perca flavescens, Lota maculosa, Naucrates ductor, Scomber colias, Siphostoma fuscum, Cryptacanthodes maculatus.

1900. Carleton, Leroy 'T., Stanley, Henty O., and Oak, Charles E.

Report of the Commissioners of Inland Fisheries and Game for the State of Maine for the year 1900 (1900).

Cited as Me. F. C. Report, 1900. 
List of species:

Salmo sebago

as Landlocked salmon

Salvelinus fontinalis

as Trout

Salmo fario*

as Brown trout

1900. Doniels, Line.

A whitefish (Coregonus labrudoricus) was caught by Line. Daniels in Sebago Lake in August, 1900, on a troll.

1900. Kendall, W. C.

List of the fishes collected in Sebago Lake basin in 1900, containing the same species, excepting Couesius plumbeus, as Kendall, 1898 and 1899.

1900. Kendill, W. C', and Gould, Thos. B.

Collections made in ILaine, 1900.

During the summer and fall of 1900, Dr. IV. C. Kendall and Col. Thos. B. Gould were engaged upon lobster and clam experiments in Casco Bay and incidentally did some collecting of fishes. In October, they were instructed to make a study of the geographical distribution of Maine freshwater fishes. Accordingly they visited Lake Auburn, Rangeley and Sebec Lakes and the East Branch of the Penobscot River waters, which regions their collections represent.

List of species :

Ameinus nebulosus, Cutostomus commersonii, Abramis crysolencas, Semotihus bulleris, Semotilus atromaculatus, Leuciscus curletoni, Lenciscus neogcus, Notropis muskoka, Notropis cornutus, Rhinichthys atronasus, Anguilla rostrata, Onocorhynchus tschawytscha, $\dagger$ Salmo salai, Salmo sebago, $\dagger$ Salmo gairdneri, ${ }^{\dagger}$ Salmo irideus, ${ }^{*} \dagger$ Salmo fario, ${ }^{\dagger}$ Salvelimus fontinalis, Salvelinus aureolus, Salvelinus oquassa, Fundulus diephanus, E'sox

*Int roduced.

-Observed or obtained at State Hatchery Pond, Auburr. 
reticulatus, Gasterosteus atkinsii, Micropterus dolomieu, Pereu flavescens, Tautoga onitis, Gadus callaris, Pollachins virens, Melanògrammus ceglefinus.

1900. Pettengill, A. $H$.

Collections of, in 1900 and previous years. Mr. Pettengill for a number of years has had a brush-weir at Wolf's Neck, Freeport, Maine, principally for the purpose of catching smelts. The law permits of the use of such fishing contrivances only from September 20th. Accordingly, Mr. Pettengill's collections represent the months of October, November and December. Occasionally fishes unknown to him are taken in the weir, which he has usually presented to the writer for identification.

List of species :

Ammodytes americanus, Morone americana, Urophycis tenuis, Urophycis chuss, Osmerus mordax, Gasterosteus aculeatus, Brevoortia tyrannus, Gasterosteus bispinosus, IVyoxocephalus ceneus, Chupea harengus, Pomatomus saltatrix, Mugit cephalus, Pungitius pungitius, Microgadus tomeod, Merlucaius bitinearis, Myoxocephalus octodecimspinosus, Fundulus heteroclitus, Psendopleuronectes americanus, Pollachius virens, Pomolobus pseudoharengus, Alosa sapidissima, Anguille rostrata, Roccus lineatus.

1900. SмITH, Hugh M.

The Sebago Lake Basin, in Report on the Inquiry Respecting Food-fishes and the Fishing-grounds.

Report U. S. Fish Commission, 1899 (1900), pp. cxxicxxiii.

List of species :

Salmo sebago

as Salmo sebago

Salmo sebago (?)

as "Jumper" 
Osmerus mordax (?)

Salvelinus fontinalis

Lisox reticulatus

Catostomus commersonii

Anguilla rostrata

Lepomis gibbosus

Micropterus dolomieu

Perca flavescens

Morone americana

Lota maculosa as Smelt

as Salvelinus fontinalis

as I ucius reticulatus

as catostomus commersonii

as Anguilla chrysypa

as Eupomotus gibbosus

as Micropterus dolomieu

as Perca flavescens

as Morone americana

as Lota maculosa

1900. Spinney, Herbert L.

Assistant light keeper at Seguin Island, sent a specimen of Neoliparis atlanticus to the writer for identification. It was picked up in a cove on Seguin Island, April, 1900.

1901. Kendall, W. C:

Collection of Cathance River, tributary of the Kennebec at Bowdoinham, May, 1901.

List of species:

Acipenser sturio, Pomolobus psendoharengus, Alosa sapidissima.

1901a. Kendall, W. C.

No additional species were collected in Sebago Lake and neighboring waters in 1901.

See Kendall, 1898, 1899 and 1900.

19016. Kendall, W. U.

Collection of fishes made in Casco Bay, tributary brooks in Freeport and tributaries of Royals River in Durbam during summer of 1901, mentioned in catalogue as Kendall Coll., $1901 \mathrm{~b}$. 
List of species:

Catostomus commersonii, Semotilus bullaris, Semotilus atromaculatus, Notropis cornutus, Cousius plumbeus, Anguilla. rostrata, C'lupea harengus, Salvelinus fontinalis, Osmerus mordax, Esox reticulatus, Fundulus heteroclitus, Pungitius pungitius, Apeltes quadracus, Morone americana.

1901. Kendall, W. C., and Gould, Thos. B.

Collections made in northern Maine, summer and fall of 1901. Most of the month of August was passed at the Debsconeag Lakes and neighboring waters, September and October on the East Branch of Penobscot River, Allagash, St. Francis, St. John River, and Eagle Lakes of Aroostook County. The latter form the eastern branch of Fish River, a tributary of the St. John.

List of species:

Ameiurus nebulosus, Catostoms catostomus, Catostomus commersonii, Pimephales anuti, Chrosomus erythrogaster, Semotilus bullaris, Semotilus atromaculatus, Leuciscus carletoni, Leuciscus neogous, Abramis crysoleucas, Notropis kendalli, Notropis cornutus, Couesius plumbeus, Rhinichthys atronasus, Anguilla rostrata, Coregonus quadrilateralis, Coregonus labridoricus, Coregonus stanleyi, Salmo salar, Salmo sebayo, Salvelinus namaycush, Salvelimes fontinatis, Esox reticulatus, Fundulus diaphanus, Pungitius mungtius, Gusterosteus atkinsii, Lepomis auritus, Lepomis gibbosus, Perca flavescens, Morone americana, Cottus aracilis, Lota maculosa.

1901. Nickerson, Alonzo R.

Report of the Commissioner of Sea and Shore Fisheries of the State of Maine, 1900 (1901).

Cited as Me. S. and S. F. Report, 1901. 
List of species:

Clupea harengus

Brevoortia tyramus

Osmerus mordax

Pomolobus pseudoharengus

Scomber scombrus

Alosa sapidissima

Roceus lineatus

Tautogolabrus adspersus

Anguilla rostrata

Pseudopleuronectes

americana (?) as Flounder

Xiphias gladias

as Herring

as Menhaden

as Smelt

as Alewife

as Mackerel

as Shad

as Bass

as Cunner

as Eel

as Swordfish

1901. Parker, Fred.

Caught a large tautog ('Tautoga onitis) at mouth of Harraseeket River, Casco Bay, and presented it to the writer.

1901. SNITH, HשGH M.

Cobbosseecontee and Sebago Lakes, Maine, in Report on the Iny uiry Respecting Food-fishes and the Fishing-grounds.

Report U. S. Fish Commission, 1900 (1901), pp. 128, 129.

List of species:

Micropterus dolomien

Iorone americana

Salvelinus fontinalis

Salmo sebago

Eucalia inconstans

Ameiurus nebulosus

Catostomus commersonii

Semotilus bullaris

Semotilus atromaculatus

Abramis erysoleucas

Anguilla rostrata as Micropterus dolomieu

as Morone americana

as Salvelinus fontinalis

as Salmo sebago

as Eucalia inconstans

as Ameiurus nebulosus

as Catostomus commersonii

as Semotilus corporalis

as Semotilus atromaculatus

as Abramis crysoleucas

as Anguilla chrysypa 
Osmerus abbottii

Esox reticulatus

Lepomis auritus

Lepomis gibbosus

Perca flavescens as Osmerus abbotti

as Lucius reticulatus

as Lepomis auritus

as Eupomotis gibbosus

as Perca flavescens

1902. Kendall, W. C.

The following list of fishes represents a collection made during the spring and early summer, Sebago Lake, Little Sebago, Freeport, Casco Bay and Lower Penobscot River waters, referred to as Kiendall Coll., 1902.

List of species:

Petromyzon marinus, Acipenser sturio, Ameiurus nebulosus, Catostomus commersonii, Semotilus atromaculatus, Semotilus bullaris, Notropis cornutus, Couesius plumbeus, Rhinichthys atronasus, Anguilla rostrata, Pomolobus pseudoharengus, Pomolobus cestivalis, Salmo salar, Salmo sebago, Salvelinus fontinalis, Osmerus mordax, Esox reticulatus, Fundulus heteroctitus, Micropterus dolomieu, Perca flavescens, Morone americana, Tautogolabrus adspersus, Pungitius pungitius, Gasterosteus aculeatus, Apeltes quadracus, Myoxocephalus octodecimspinosus, Pollachius virens, Microgadus tomcod, Urophycis chuss (?), Merluccius bilinearis, Microgadus tomeod, Pseudopleuronectes americanus.

1902A. KENDALL, W. C.

Notes on the Silversides of the genus Menidia, of the east coast of the United States, with descriptions of two new sub-species.

Report U. S. Fish Commission, 1901 (1902), pp. 241-267. [Menidia menidia notata.]

1902. Kendall, W. C., and Gould, Thos. B.

Collectors of, in Moosehead Lake and East Branch of Penobscot River waters during summer and fall of 1902. 
List of species:

C'atostomus commersonii, Pimephales anuli, Semotilus bullaris, Semotilus atromaculutus, Abramis crysolencas, Notropis cormutus, Lenciscus noyaus, Cousius plumbeus, Rhinichthys atronasus, Anguilla rostrata, Salmo salar, Salmo sebago, Salvelinus namaycush, Salvelims fontinalis, Esox reticulatus, Gasterosteus, athinsii, Lepomis auritus, Lepomis gibbosus, Nicropterus dolomien, Perca flavescens.

1902. Sinth, Hugh M.

River and Lake Fishes of Maine, in Report on the Inquiry Respecting Food-fishes and the Fishing-grounds.

Report U. S. Fish Commission, 1901 (1902), pp. 111-112.

List of species :

Salmo silar

Salmo sebago

Osmerus mordax (?)

Salvelinus oquassa

Leuciscus carletoni

Leuciscus neogreus

Notropis kendalli

Fundulus diaphanus

Gasterosteus atkinsii

Semotilus atromaculatus

Pomatomus saltatrix

Brevoortia tyrannus

Morone americana

Mugil cephalus

as Salmon-like fish

as Salmo sebago

as Fresh-water smelt

as Salvelinus oquassa

as Leuciscus sp. (?)

as Leuciseus sp. (?)

as Notropis muskoka

as Fundulus diaphanus

as Gasterosteus atkinsii

as Semotilus atromaculatus

as Pomatomus (young)

as Brevoortia (young)

as Morone

as Mugil cephalus

1903. Atkins, Charles $G$.

Collector and observer. List submitted to Bureau of Fisheries, February 5, 1903.

List of species :

Petromyzon marinus (?)

Ameiurus nebulosus

as Lampetra wilderi

as Ameiurus nebulosus 
Catostomus catostomus

Catostomus commersonii

Erimyzon oblongus

Semotilus bullaris

Semotilus atromaculatis

Abramis crysoleucas

Notropis cornutus

Rhinichthys atronasus

Anguilla rostrata

Coregonus quadrilateralis

Coregonus labradoricus

Osmerus mordax

Osmerus spectrum

Osmerus abbottii

Salmo sebago

Salvelinus namayeush

Salvelinus fontinalis

Salvelinus oquassa

Salvelinus aureolus

Esox reticulatus

Fundulus diaphanus

Garsterosteus atkinsii

Gasterosteus atkinsii

Lepomis auritus

Lepomis gibbosus

Micropterus dolomieu

Perca flavescens

Morone americana

Cottus gracilis

Lota maculosa as Catostomus catostomus

as Catostomus commersonii

as Erimyzon sucetta

as Semotilus corporalis

as Semotilus atromaculatus

as Abramis crysoleucas

as Notropis cornutus

as Rhinichthys atronasus

as Anguilla chrysypa

as Coregonus quadrilateralis

as Coregonus labradoricus

as Osmerus mordax

as Osmerus mordax spectrum

as Osmerus mordax abbottii

as Salmo salar sebago

as Cristivomer namayeush

as Salvelinus fontinalis

as Salvelinus oquassa

as Salvelinus alpinus aureolus

is I ucius reticulatus

as Fundulus diaphanus

as Gasterosteus bispinosus

atkinsii

as Gasterosteus bispinosus

$$
\text { cuvieri (?) }
$$

as Lepomis auritus

as Eupomotis gibbosus

as Micropterus salmoides (?)

as Perca flavescens

as Morone americana

as Uranidea quiescens

as Lota maculosa 
19) Beriy, II. L.

A fine collection of Osmerus alibottii was made by $\mathrm{Mr}$. Berry and sent to the Bureau of Fisheries by request of State Commissioner, Hon. H. O. Stanley.

1908. BoARDMAN, SAMUEL LANE.

The Naturalist of the St. Croix. Memoir of George A. Boardman. A selection from his Correspondence and Published Writings. Notices of Friends and Contemporaries, with his Lists of the Birds of Maine and New Brunswick.

Bangor, privately printed.

Contains a few scattered notes on the occurrence of a number of fishes in his letters to S. F. Baird, and at pages 316319 , a nominal list of ninety-three alleged species of Maine and New Brunswick fishes. The list is very erroneous and valueless.

1903. Carleton, L. 'T., Stanley, Henry O., and Ring, Eugali E.

Report of the Commissioners of Inland Fisheries and Game for the State of Maine for the year 1902 (1903).

Cited as Me. F. C. Report, 1903.

List of species:

Coregonus sp.

Śalmo sebago

Salvelinus fontinalis

as Whitefish

as Landlocked salmon

as 'Trout

\section{Garland, C. C.}

In Rainbow Lake and Rainbow Stream, in May, 1903, twenty-five or thirty saibling were said by Mr. Garland to have been caught in the pool below the dam at foot of the lake. He secured one from the anglers; another specimen was caught in the upper end of Rainbow Lake. [Salvelims oquassa (?) and Rhinichthys atronasus.] 
1903. Hamlin, Augustus C., M. D.

Salmo toma or togue [Salvelinus namaycush].

Maine Sportsman, May, 1903.

See Hamlin, 1853 (?).

190\%. Kendall, W. C.

Collector of, in Sebago, Royals, Androseoggin, Penobscot, Union and St. John river basins, and in Caseo Bay, Me., season of 1903 .

List of species:

Ameiurus nebulusis., Catostomus commersonii, Catostomus "utustomus, Chrosomus erythrogaster, Pimephales anuli, Semotilus bullaris, Semotilus atromuculatus, Lencisens carletoni, Phoximus nengens, Abramis arysolencas, Notropis comutus, Notropis kendalli, Coniesius plumbeus, Rhinichthys atronasus, Angnilla rostrata, Chupea harengus, Pomolobus psendoharengus, Essox reticulatus, Coregonus labradoricus, Coregomus stanleyi, Coregonus quadrilateralis, Salmo salar, Salmo sebago, Salvelinus namaycush, Salvelinus, fontinalis, Salvelinus oquassa, Salvelinus: anvenlus, Fundulus diaphanus, Fundulus heteroctitus, Pungitins pungitius, Gasternstens andeatus, Gasterostens bispinusus, Apeltes quadracus, Osmeruss mordax, Lepomis auritus, Lepmis gibbosus, Mirroptems dolomien, Perea flavescens,

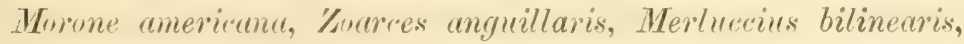
Lrophycis temuis, Pollachins virens, Gadus callarias, MelanoIrcemmus aglefinus, Lota maculosa, Tantogolabrus adspersus, Psendopleurmectes americans, Hemitripterns ameriramis, My"xoncephalus octudecimspinusus.

1903A. Kendali, W. C.

Notes on some fresh-ivater fishes from Maine.

Bulletin U. S. Fish Commission, Vol. XXII, 1902 (1904), pp. 355-368. 
List of species :

Chrosomus erythroyaster, Semotilus atromaculatus, Notropis kendalli as Votropis muskoka, Conesius plumbens, Fundulus diaphanus, Eucaliu incmstans, Nerracion mbilianus as Narrine meridentalis, Gasterosteus bispinosus as Gusterwsteus whentlandi, Mugil cephalus as Musil anema, Stenotomus chrysopss, Centropmistes striatus, Wenticirhus suxatilis, Prionotus carolinus, Spheroides maculatus, Lophopsetta maculate, Macrourus bairdi, Catostomus ratostomus, C'atostomus rommersonii, Pleoximes nengens, Lenciscus rurletmi (type), Pimephales amuli (type), Notropis bitivenutus, Cottus gracilis, Coregonus labradoricus, Coregonus quadrilaterulis, Coregumus stanleyi (type), Coresumus labradoricus.

19():). Lee, Leslie A.

A small collection made in a ditch connected with the l'enobscot River' at Bangor, October 1, and one species at Dixmont, October 10,1903 , are recorded here as I.ee Coll., 1908.

List of species:

Chrosmmus erythrogaster, Leneiscus carletwni, Rhinichthys: atronessus, Pungitius mongitins.

\section{Nickelison, Alonzo R.}

Report of the Commissioner of Sea and Shore Fisheries of the State of Maine, 1902 (1903).

Cited as Me. S. and S. F. Report, 1903.

List of species:

Clupea harengus

Brevoortia tyranuus

Osmerus mordax

Pomolobus pseudoharengus

Scomber scombrus
as Herring
as Menhaden
as Smelt
as Alewife
as Mackerel 
Alosa sapidissima

Salmo salar

Roceus lineatus as Shad

as Salmon

as Bass

\section{Norton, A. H.}

Observed a few fishes, and secured specimens of one or two more, brought ashore by Aretic terns as food for their young, at Matinicus Rock. The species eited in this paper are Anguilla rostrata and Ulvaria subbifurcuta.

\section{SiITH, Hugh M.}

Report on the Inquiry Respecting Food-fishes and the Fishing-grounds.

Report U. S. Fish Commission, 1902 (1903), pp. 132-134.

List of species:

Salvelinus fontinalis

Salvelinus namayeush

Semotilus bullaris

Semotilus atromaculatus

Salmo salar

Coregonus stanleyi

Coregonus quadrilateralis Coregonus labradoricus

Gasterosteus atkinsii

Conesius plumbeus as Brook trout

as Cristivomer namayeush

as Semotilus corporalis

as Semotilus atromaculatus

as Small salmon

as Coregonus

as Coregonus quadrilateralis

as Coregonus labradoricus

as Gasterosteus atkinsii

as Conesius plumbeus

\section{0\%. Stanley, H. O.}

The Bureau of Fisheries at Washington received six whitefish from M. Alva Cooledge, Upton, Me., whom Mr. Stanley got to secure the fish. Upon examination they seemed to be Coregonus clupeaformis.*

*Introduced. 
1903. T'ownsend, Will.

Caught a fair-sized tautog ('T'autoga onitis) in tidal portion of fresh water brook, Porter's Landing, while dipping smelts in the spring.

\section{9)0.4. Bowman, A. C.}

In a letter to Mr. T. E. B. Pope, of the U. S. Bureau of Fisheries, dated Feb. 1, 1904, Mr. Bowman, of Hartland, enumerates the fishes of Moose Pond, Indian Pond and Sebasticook River.

List of species:

Ameiurus nebulosus

Catostomus commersonii

as Hornpout

Semotilus bullaris

(?)

Anguilla rostrata

Anguilla rostrata

Salmo sebago

as Suckers

as Chub

as Shiners

as Common eel

as Silver eel

as Landlocked salmon

Salvelinus fontinalis

as Square-tail trout

Osmerus abbottii

as Fresh-water smelt

Esox reticulatus

as Pickerel

Lepomis auritus or

Lepomis gibbosus or both

Micropterus dolomieu

as Sunfish

Perca flitvescens

as Black bass

Morone americana

I ota maculosa

as Yellow perch

as White perch

as Cusk

\section{EVERMANN, BARTON W.}

The Salmon Fisheries of Penobscot River and Bay in Report of the Division of Statistics and Methods of the Fisheries.

Report U. S. Fish Commission for year ending June 30, 1903 (190t), pp. 110-114. 
List of species:

Petromyzon murinus, Squalus acuntlias, Acipenser sturit, Anguilla rostrata, C'lupea harengus, Pomolobus psendoharengus, Pomolobus cestivalis, Alosa sapidissima, Brevoortia tyranmus, Salmon [Salmo salar], Osmerus mordax, Fundulus heternrlitus, Scomber scombrus, Roceus lineatus, T'autogolabrus. adspersus, Tantoga mitis, Myoxocephalus gronlandicus, Cycloptems lumpus, Merlucius bilinearis, Pollachius virens, Gadus. rallarias, Mirogadus. tomcod, Pseudopleuronectes americanus, Lirpsetta putnami.

1904. KeNDall, Dr.W. C.

Identifying the Catch [with additional title at page 43], Game and Food Fishes [and at page 61], Bait Fishes.

In the Maine Woods, edition of 1904. The Vacationists' Guide Book, Published by the Bangor and Aroostook Railroad Company, Bangor, Me., pp. 34-66.

Food fishes:

Salmo salar, Salmo sebago, Salmo yairdneri,* Salmo irideus, Salmo furio, Sulvelinus namaycush as Cristivomer namaycush, Salvelinus fontinalis, Coregoms labradoricus, Coregonus quadrilateratis, Coregonus stanleyi, Micropterus dolomieu, Morone americana, Esox reticulatus, Perca flavescens, Lepomis auritus, Lepomis gibbosus as Eupomotis gibbosus, Lota maculosa, Ameiurus nebulosus, Anguilla rostrata as Anguilla chrisypa.

Bait fishes :

Osmerus mordax, Semotilus bullaris as Semotilus corporalis, Semotilus atromaculatus, Leuciscus carletoni, Phoxinus neogous, Abramis crysoleucus, Votropis cornutus, Couesius plumbeus, Rhinichthys atronasus, Fundulus diaphanus.

1904. Garland, C'. C'.

In the fall of 1904 Mr. Garland collected two specimens

* Introduced. 
of the saibling of Rainbow Lake, which cannot be definitely distinguished from the small blueback that formerly occurred in Rangeley Lakes, with which speries it is here provisionally identified (Salvelinus oquassa).

\section{Kendall, W. C.}

Collections and observations made in Casco Bay, at Eagle and Whaleboat Islands; Freeport in Porter's Landing, Harvey Brook and South Fork of East Branch of Royals River: Durham and Pownal in "The Branch"; Floods Pond; Rangeley, Kennebago and Cupsuptic Streams and Oquossoc and Mooselucmaguntic Lakes; Carry and Pierce Ponds, are referrerl to as Kendall Coll., 1904.

list of species:

Ameinous nebulosus, Catostomus commersonii, Semotilus bullaris, Semotilus atromaculatus, Notropis comntus, Rhinichthys atronasus, Comesius plumbens, Pomolobus psendoharengus, Salmo sphago, Salvelinus namaycush, Salvelims, fontinalis, Salnelinus oquassa, Salvelinus aureolus, Osmernes modax, Anguillu rostrata, Esox reticulatus, Fundulus diaphanus, Fundulus hetcroclitus, Gasterusteus aculeatus, Gasterosteus atkinsii, Lepomis anritus, Zoaress anguillaris, Pollarhius virens, Gadus collarios, Melanogrammus reglefinus.

\section{Sinth, Hugh M.}

Atlantic Salmon, Salmon of Penobscot Basin, in Report on Inquiry Respecting Food-fishes and the Fishing-grounds.

Report U.S. Fish Commission for the year ending June $: 30,1903$ (1904), pp. 81, 82. [Salmon.]

1905. Carleton, L. T., Stanier, Henti A., Ring, EDGAll E. .

Report of the Commissioners of Inland Fisheries and Game of the State of Maine for the year 1904 (1905).

Cited as Me. F. C. Report, 1905. 
List of species :

Salmo sebago

Salvelinus fontinalis

Salmo gairdneri**

Salmo fario*

Salvelinus namaycush

Salmo irideus* as, Salmon

as Trout

as Steelhead trout

as Brown trout

as 'Togue

as Rainbow trout

Oncorhynchus tschawytscha as Quinnat salmon

\section{EVERMANN, BARTON W.}

Investigations in Maine, in Report on Inruiry Respecting Food-fishes and the fishing-grounds.

Report of Commissioner of Fisheries to the Secretary of Commerce and Labor for the year ending June 30, 1904, pp. 102-106.

List of species :

Salmo sebago, Salvelinus namaycush, Salvelinus, fontinalis, Coregonus quadrilateralis, Coregonus labradorious, Coregonus stanleyi, yellow perch [Perca flavescens], (Ismens mordax, C'atostomus commersonii, Lota maculosa, Salvelinus aureolus, a peculiar trout [Salvelimus oquessa], Rhinichthys atronasus, Pomolobus pseudoharengus, Pungitius pungitius, Gusterostens aculeatus, Gasterosteus bispinosus, Apeltes quadrums, Fundulus heteruclitus, young eels [anguilla rostrata].

190i). Kendall, W. C:

Collections made in Umbagog I ake and vicinity. Referred to as Kendall Coll., 1905.

List of species:

Ameiurus nebulosus, Catostomus catostomus, Catostomus. commersonii, Semotilus bullaris, Semotilus atromaculatus. Phoximes neogens, Abramis rrysolencas, Notropis cornutus,

*Introduced. 
Coussius plumbers, Rhinichthys atronasus, Coregonus clupeaformis,* Salmo sebago,* Salvelinus, fontinalis, Osmerus moidax*, Esox retirulatus.

1905. Nickerson, Alonyo Kí.

Tiventy-eighth Report of the Commissioner of Sea and Shore Fisheries of the State of Maine for 1903 and 1904 (1905).

Cited as Me. S. and S. F. Report, 1905.

List of species:

Clupea harengus

Osmerus mordax

as Herring

as Smelt

Pomolobus pseudoharengus as Alewife

Scomber scombrus

as Mackerel

Alosa sapidissima

as Shad

Salmo salar

as Salmon

Brevoortia tyrannus

as Menhaden

Roceus lineatus

as Bass

Tautogolabrus adsper'sus

as Cunner

Anguilla rostrata

as Eel

Pseudopleuronectes

Xiphias gladius

americanus as Flounder

Microgadus tomeod

as Swordfish

as Tomeod

\section{0's and $1906^{\circ}$. Norton, A. H.}

During each of the winters of the years cited a specimen of Isurus punctatus was brought into Portland from the fishing grounds off Cape Elizabeth. Both were adult females, each carrying, after the well known manner of Squalus acanthias, a pair of young.

The sharks were identified by Mr. Norton, and are cited as Norton coll., 1905 and 1906.

\footnotetext{
"Introduced.
} 
1905. WILtaAR, CAPT. BENIAMIIN J.

Captain Ben's Book. A Record of the things which Happened to Captain Benjamin J. Willard, Pilot and Stevedore, During some Sixty Years on Sea and Land, As Related by Himself.

Portland, Me., Lakeside Press, 1905.

Contains numerous notes and two illustrations on fisbing for sport and for profit, at points between Boon Island and Mt. Desert, with remarks and descriptions of methods.

The fishes mentioned are "Blue Shark" [Isurus punctatus], "Dusky or Man-eater Shark" [Careharinus obsemms], "Trout" [Salvelimus , fontinulis], "Swordfish" [Xiplias gladins], "Sunfish" [Mola mola], and "Codfish" [Gadus vellarios].

The capture of the dusky shark (taken outside of Cod Ledge during the summer of 1864) is fully given at pages 97-99. Willard states that it was identified by Mr. Charles [13.] Fuller, cabinet keeper of the Portland Society of Natural History, and that the shark was given to that Society to be mounted, where it was destroyed "at the time of the big fire," which oceurred July 4, 1866.

1906-1919. Kendall, W. C.

Collection made in the Presumpscot River or Sebago Lake basin.

Additional species to preceding lists were Couesius plumber.s: again, Pungitius pungitius, Cottus aracitis.

\section{Norton, A. H.}

Collected on Old Orchard beach a specimen in the postlarval stage of Leptocephalus conger.

\section{0\%. Bowdoin College.}

Echeneis naucrates. A specimen taken in a herring weir at Slen's Island, Seal Harbor, St. George (Knox Co., Me.), 
July 29, 1907, was sent to Bowdoin College by Prof. Charles Wilbert Snow. Cited as Bowdoin College Coll., 1907.

1907. Carletox, L. 'T., Brackett, J. W', and Ring, EDgar E.

Report of the Commissioners of Inland Fisheries and Game for the State of Maine for the year 1906 (1907).

Cited as Me. F. C. Report, 1907.

List of species:

Salvelinus fontinalis

Salmo fario*

as 'Trout

Salmo sebago

as Brown 'Trout

Stizostedion vitreum*

as Salmon

()ncorhynchus tschawytscha* as Quinnat salmon

1907. Nickerson, Alowzo R.

Twenty-ninth Report of the Commissioner of Sea and Shore Fisheries of the State of Maine for 1905 and 1906 (1907).

Cited as Me. S. and S. F. Report, 1907.

List of species:

Squalus acinthias

Clupea harengus

Scomber scombrus

Alosa sapidissima

Osmerus mordax

Pomolobus pseudoharengus

Salmo salar

Roceus lineatus

Tautogolabrus adspersus

Anguilla rostrata

P'sendopleuronectes

americanus as Flounder as Dogfish

as Herring

as Mackerel

as Shad

as Smelt

as Alewife

as Salmon

as liass

as Cumner

as Eel

*Introiluced. 
Xiphias gladius

Microgadus tomeod as Swordfish

as 'Tomeod

1908. Carleton, L. T., Brackett, J. W., and Ring, EDGAR E.

Report of the Commissioner's of Inland Fisheries and Game for the State of Maine for the year 1907 (1908).

Cited as Me. F. C. Report, 1908.

Salmo sebago

Salmo fario*

Salvelinus fontinalis as Landlocked salmon

as Brown trout

as Trout

\section{Kexdall, William C.}

Fauna of New England. 8. List of Pisces.

Occasional Papers of the Boston Society of Natural History, Vol. VII, 1908.

Said list contains all the Maine species included in this catalogue, with the following exceptions, namely:

Carcharinus abscurus, Etrumens teres, Hyporhamphus roberti, Echeneis naucrates, Leptoclinus maculatus, Lycenchelys verrillii, Hippoglossoides platessoides and Artediellus atlanticus.

The nomenclature has been changed in the following species, that used in this catalogue being given first.

List of species:

Vulpecula marina

Careharius taurus

Isurus tigris :

Isurus punctatus

Raia erinacea

Raia diaphanes

Raia radiata

Raia stabuliforis as Alopias vulpes

as Carcharius littoralis

as Isurus dekayi

as Lamma cornubica

as Raja erinacea

as Raja ocellata

as Raja radiata

as Raja lievis

"Introduced. 
Narcacion nobilianus

Notropis kendalli

Anguilla rostrata

Salvelinus namayeush

Siphostoma fuscum

Scomber colias

Lampris luna

Lepomis gibbosus

Lycenchelys verrillii as Tetronarce occidentalis

as Notropis muskoka

as Anguilla chrisypa

as Cristivomer namaycush

as Syngnathus fuseus

as Scomber japonicus

as Lampris regius

as Eupomotis gibbosus

as Lycodes verrillii

1908. Norton, Ralph H.

November 6, 1908, Mr. Norton presented to the collection of the Portland Society of Natural History a specimen of Mugil cephalus, taken two or three days previously at Clapboard Island, Casco Bay. It has been examined by the author of this work.

19)S. Porthend Society of Notural Society.

An ummounted skin, with jaws of Isurus tigris, taken in nets off Seguin September 14, 1908, is cited as P. S. N. H. Coll., 1908.

1909. Carletos, I. T., Brackett, J. W., and litsg, liDiar E.

Report of the Commissioners of Inland Fisheries and Game for the State of Maine for the year 1908 (1909).

Cited as Me. F. C. Report, 1909.

List of species:

Salmo sebago

as Salmon

Salvelinus fontinalis

as 'Trout

Salvelinus namaycush

as 'Togue 
1909. DONAHUE, JAMES.

'Thirtieth Report of the Commissioner of Sea and Shore Fisheriès, State of Maine, 1907 and 1908 (1909).

Cited as Me. S. and S. F. Report, 1909.

List of species:

Pomolobus pseudoharengus as Alewife

Roccus lineatus

as Bass

Anguilla rostrata

as Eel

Clupea barengus

as Herring

Scomber scombrus

as Mackerel

Brevoortia tyranuus

as Menhaden

Salmo salar

as Salmon

1909. EvermanN, Barton Warren, and Cockerel, 'THEODORE D. A.

Proceedings Biological Society of Washington, Vol. XXII, pp. 185-188.

Description of Notropis kendalli. This species is based upon specimens of fish identified by Kendall as Notropis muskokr.

1911. Bracketr, J. W.,. Viles, Blaixe S., and Ring, EDgar E.

Report of the Commissioners of Inland Fisheries and Game for the State of Maine for the year 1910 (1911).

Cited as Me. F. C. Report, 1911.

List of species:

Salmo sebago

Salvelinus fontinalis

Salvelinus namayeush

Salvelinus fontinalis

Salmo fario* as Landlocked sạlmon

as 'Trout

as Togue

as Square-tailed trout

as Brown trout

"Introduced. 
1911. DONAHUE, JaMES.

'Thirty-first Report of the Commissioner of Sea and Shore Fisheries, State of Maine, 1909 and 1910 (1911).

Cited as Me. S. and S. F. Report, 1911.

List of species:

Pomolobus pseudoharengus as Alewife

Roceus lineatus as Bass

Anguilla rostrata as Eel

Clupea harengus as Herring

Scomber scombrus as Mackerel

Alosi sapidissima as Shad

(Osmerus mordax as Smelt

\section{1 and 191.2. Racklift, Evan D.}

During the summer of each of these years Mr. Rackliff caught a large sunfish (Mola mola) near Cod Ledge, off Casco Bay.

\section{Rackliff, Hred.}

Collected two specimens of Prionutus corolinus in a herring wier on the west side of Mt. Desert Island in the summer of 1911, one of which he mounted and presented to the collection of the Portland Society of Natural History.

\section{1\%. Powers, W. L.}

Rough drawing and a description of a halfbeak, ten and one-half inches long, probably Hyporhamphus roberti, caught in a weil two miles from open ocean, May, 1912, Machias.

\section{1: and 191:). Welsh, W. IV.}

Collected Argentina silus off the Maine coast as follows:

One young example, $49 \mathrm{~mm}$. long, Grampus Station No. 10027, August 14, 1912, in closing net at 35 fathoms, thirtythree miles sonth from Mt. Desert Rock, Me. 
One young example, $38 \mathrm{~mm}$. long, Grampus Station No. 10097, Aug. 13, 1913, twenty-five miles southeast from Petit Manan light.

1913. Copelund, Di. Manton.

Sent the writer for examination a specimen of Hyporhamphus roberti from the collection of Bowdoin College, which had been collected, at "Bunganuc" (Brunswick), Maqquoit Bay, October, 1912.

1913. Donahue, James.

Thirty-second Report of Commissioner of Sea and Shore Fisheries, State of Maine, 1911 and 1912 (1913).

Cited as Me. S. and S. F. Report, 1913.

List of species:

Pomolobus pseudoharengus as Alewife

Roccus lineatus as Bass

Anguilla rostrata as Eel

Clupea harengus as Herring

Seomber scombrus as Mackerel

Brevoortia tyrannus

Salmo salar as Menhaden as Salmon

1913. Kéendall, William Converse.

Fishes and Fishing in Sunapee Lake.

[U.S.] Department of Commerce, Burenu of Fisheries, Document No. 783.

List of species:

Coregonus clupeaformis, Oncorhynchus tschinoytsche, Salmo sebago, Salvetinus oquassa, Salvelinus aurealus, Osmerus mordax.

191\%. Kendall, Dr. W. C.

Observations made on the Maine coast between Lastport and Portland, July, August and September, eited as Kendall coll., 1913. 
1913. Wilson, J. S. P. H., Viles, Blaine S., and MACE, F. E.

Report of the Commissioners of Inland Fisheries and Game for the State of Maine for the year 1912 (1913).

Cited as Me. F. C. Report, 1913.

List of species:

Salmo sebago

Salvelinus fontinalis

Salvelinus namaycush

Salmo fario* as Landlocked salmon as Square-tailed trout as Togue

as Brown trout

1914. Bigelow, Henry B.

Explorations in the Gulf of Maine, July and August, 1912, by the U. S. Fisheries Schooner Grampus. Oceanography and Notes on the Plankton.

Bulletin Museum of Comparative /oology at Harvard College, Vol. LVIII, No. 2, pp. 31-147, pls. 1-9.

At page 107 oecurs a list of fishes (identified by W. W. Welsh, U.S. Bureau of Fisheries). In this list numerous Maine specimens are recorded. The list is divided in two sections: 1. Larval and post-larval stages taken in the plankton hauls (pp.107-111), and [2.] adult stages taken in the trawl (pp. 111-114).

One species, Artediellus atlanticus, is additional to the catalogue of Maine fishes (see addenda, page 73), and several others are rare.

This paper appeared too late to allow the records to appear in their proper places in the catalogue, and therefore the Maine specimens and stations are given in full here.

Raia erinacea-Southward of Seguin in 60 fathoms.

Osmerus mordax-Portland Harbor.

Gusterosteus aruleatus-Southeastivard of Boon Island. 
Siphostoma fuscum-Portland Harbor.

T'autogolabrus adspersus-Kittery Harbor; Orr's Island; - Casca Bay.

Cyolopterus lumpus--Southeastward of Monhegan; between Petit Manan and Libby Island.

Lycenchelys verrillii--Off Monhegan in 60 fathoms.

Zoarces anguillaris-Off Halfway Rock in 30 fathoms.

Ulvaria subbifurcata-Off Seguin in 25 fathoms; southeastwardly of Cape Porpoise in 20 fathoms; Casco Bay in 7 fathoms.

Myoxocephalus octodecimspinosus - Southeastward of Cape Elizabeth in 50 fathoms; near Halfway Rock in 16 fathoms.

Artediellus atlanticus_Off Casco Bay in 40 fathoms; southward of Monhegan in 60 fathoms.

Hemitripterus americanus-Off Halfway Rock in 30 fathoms; southward of Monhegan in 60 fathoms.

Sebastes marinus-Southward of Cape Porpoise in 30 fathoms; southeastward in 20 fathoms; off Seguin in 25 fathoms; southeastward of Cape Elizabeth in 50 fathoms, and in 20 fathoms; southward in 30 fathoms, and northward of Monhegan in 60 fathoms.

Aspidophoroides monopterygius-Off Halfway Rock in 30 fathoms; southward of Monhegan in 60 fathoms.

Merhuccius bilinearis-Off Halfway Rock in 30 fathoms; off Seguin in 25 fathoms; southward of Monhegan in 60 fathoms; Kittery Harbor and Orr's Island.

Melanogrammus ceylefinus--Off Halfway Rock in 30 fathoms; off Seguin in 25 fathoms.

Gadus callarias-Southeastward of Boon Island in 25 fathoms.

Urophycis regius-Near Halfway Rock in 11 fathoms. 
Urophycis chuss - Southward of Cape Porpoise in 30 fathoms; off Halfway liock in 30 fathoms; off Seguin in 25 fathoms; southward of Monhegan in 60 fathoms.

Enchelyopus cimbrius-Southeastward of Boon Island in 30 fathoms, and in 5 fathoms; off Halfway Rock in 30 fathoms; Orr's Island; Casco Bay; off Seguin in 25 fathoms.

Hippoglossoinles platessoides - Sontheastward of Boon Island in 25 fathoms; southward of Cape Porpoise in 30 fathoms; off Halfway Rock in 30 fathoms; oft Seguin in 25 fathoms; southward of Monhegan in 60 fathoms.

Psendoplenronectes americuns-Near Halfway Rock in 11 fathoms: Casco Bay.

Limunda, fermginen-Off Halfway Rock in 30 fathoms.

Calyptocephalus cynoglussus - Southeastward of Cape Porpoise in 20 fathoms; off Seguin in 25 fathoms; southward of Nonhegan in 60 fathoms.

Lophius piscatmins - Off Halfway Rock in 30 fathoms; southward of Monhegan in 60 fathoms.

\section{Johxson, Robert S.}

The Distribution of Fish and Fish Eggs During the Fiscal Y ear 1913.

Department of Commerce. Appendix I to Report [U.S.] Commissioner of Fisheries for 1913 (1914).

U. S. Bureau Fisheries, Document No. 749.

List of species:

Salvelinus fontinalis

as Brook trout

Salmo sebago

Salmo salar

Osmeris mordax

Ameiurus nebulosus

as Landlocked salmon

as Atlantic salmon

Oncorhynchus kisutch*

as Smelt

as Catfish

as Silver salmon

"Introduced. 
Salvelinus namayeush

Micropterus dolomieu

Morone americana

Gadus callarias

Melanogrammus ieglefinus

Psendopleuronectes as lake trout

as Smallmouth black bass

as White perch

as $\mathrm{Cod}$

as Haddock

amerieanus as Flatfish

\section{Kexdall, Willian Converse.}

The Fishes of New England. 'The Salmon Family. Part

1. The 'Trouts or Charrs. With seven plates.

Monographs on the Natural History of New England.

Memoirs of the Boston Society of Natural History, Vol. 8, No. 1, pp. (1) 103, pls. $1-7$.

List of species :

Salvelinus namaycush, Salvelinus oquassu, Salvelinus aureolis, Salvelimus, fontinalis.

1914. Wilsox, J. S. P. H., NeAL, WAlteli I., and VILES, BLAINE S.

Report of the Commissioners of Inland Fisheries and Grame for the State of Maine for the year 1913 (191t). Not cited in catalogue.

List of species :

Salvelinus fontinalis

Salmo sebago

Salvelinus namaycush

Salmo fario** as Square-tailed trout

as Landlocked salmon

as Togue

as Brown trout

-Introduced. 


\section{ERRATA.}

Page 4. In the foreign list of introduced fishes for lenensis read levenensis.

Page 11. For Tsurus punctatus read Isurns tignis (Atwood).

Page 28. For Breevoortin [?] read Brevourtia.

Page 44. In footnote for yladumculus read gladiunculus.

Page 45. For Mugil Cephalus read Mugil cephahus.

Page 60. In "Range" of Cyctopterus lumpus read South to Chesapeake Bay.

Page 67. For ceglifinus read reglefinus.

Page 77. Add Lepomis auritus to Union River basin.

Page 84. In Fiddlers Reach for Daubling point read Doubling Point.

Page 105. "Identification" Melanogrommus ceglifinus read reglefinus.

Page 106. For Alopias vulpes read Tulpecula marina.

Page 110. In list of species, first column, for reglifinus read reglefinus.

Pages 127, 128 and 133, in first column, for aglifinus read cglefinus. 




\section{PORTLAND SOCIETY OF NATURAL HISTORY.}

\section{JOURNAL.}

Vol. I, No. 1 (all ever issued). Morse. Pulmonifera of Maine. 63 pp., 10 pls., numerous text cuts. Few copies only.

\section{PROCEEDINGS.}

Vol I, complete. 230 pp., 2 pls., 1 map, numerous cuts and index.

Vol. I, Part 1. $96+$ xiv pp., 1 pl, 1 map. Sold only with complete sets.

Vol. I, Part 2. $125+\mathrm{x}$ pp., $1 \mathrm{pl}$., numerous cuts and index to volume.

Cooke, M. C. Decades of Maine Fungi. 7 pp., numerous cuts (extract Proc., 1: ii). Few copies.

Billings, E. Fossils from Square Lake, Maine. 22 pp., folding plate (extract Proc., 1: ii). Few copies.

Wood, Wm. Clio borealis on the Coast of Maine. 3 pp., cut (extract Proc., 1: ii). Few copies.

Vol. II, complete. $282 \mathrm{pp} ., 5 \mathrm{pls}$, , one cut, in text.

Vol. II, in Parts.

Part 1. Brown, N. C. Rare Birds in the Vicinity of Portland. Only with complete sets.

Brown, N. C. Catalogue of Birds of Portland, with Supplement. $40 \mathrm{pp}$. Few copies only.

Part 2. Fernald, M. L. Catalogue of Maine Plants. $32 \mathrm{pp} . \quad \$ .50$

Part 3. Fernald, M. L. Supplement to Catalogue of Maine Plants. $24 \mathrm{pp}$.

Part 4. Norton, A. H. Sharp-tailed Finches of Maine, and Norton, A. H. Ornithological Notes. $8 \mathrm{pp}$.

Morton, F. S. Foraminifera of Marine Clays of Maine $18 \mathrm{pp}$. $1 \mathrm{pl}$.

Fernald, M. L. Second Supplement to Maine Plants. 15 pp. $\$ .15$

Part 5. Norton, A. H. Birds Bowdoin Labrador Expedition. 20 pp., 1 pl.

Kingsley, J. S. Catalogue Marine Invertebrata of Casco Bay, Maine. $25 \mathrm{pp}$.

Manning, P. C. Glacial Pot-Holes in Maine. $15 \mathrm{pp} ., 2 \mathrm{pl}$.
Part 6. Howe, R. H., jr. New Race of Microtus pennsylvanicus. 2 pp., 1 pl.

Part 7. Kingsley, J. S. Additions to Recorded Fauna of Casco Bay. 3 pp.

Part 8. Kendall, W. C. Fishes of Labrador. $37 \mathrm{pp}$.
Norton, A. H. Land and Fresh Water Crustaceans of Maine, 11 pp., 1 cut.

Part 9. Collins, F. S. Marine Algae of Casco Bay. 25 pp. $\$ .25$

Vol. III, Part 1. Kendall, W. C. Fishes of Maine. 


\section{MISCELLANEOUS PAPERS.}

Portland Catalogue of Maine Plants, 1868. 12 pp.

Wood, Wm. Vegetable Structure and the Importance of Certain Tissues in the Reparation of Wounds in Trees and Shrubs (May 2, 1881).

Hill, Thomas. Phyllotaxis.

Boyd, Chas. H. Walrus Remains at Addison, Maine. Stone, G. H. Glacial Erosion.

Lee, L. A. Account of the Work of the United States Fish Commission for the year 1881 .

Stone, G. H. Columbite in Maine and Reports of Officers of the Society.

Report of the President, Dr. Wm. Wood, May 20, 1889, with Memoir on Rev. J. W. Chickering, former President. 





\section{Why}

to VVINOSHIIWS
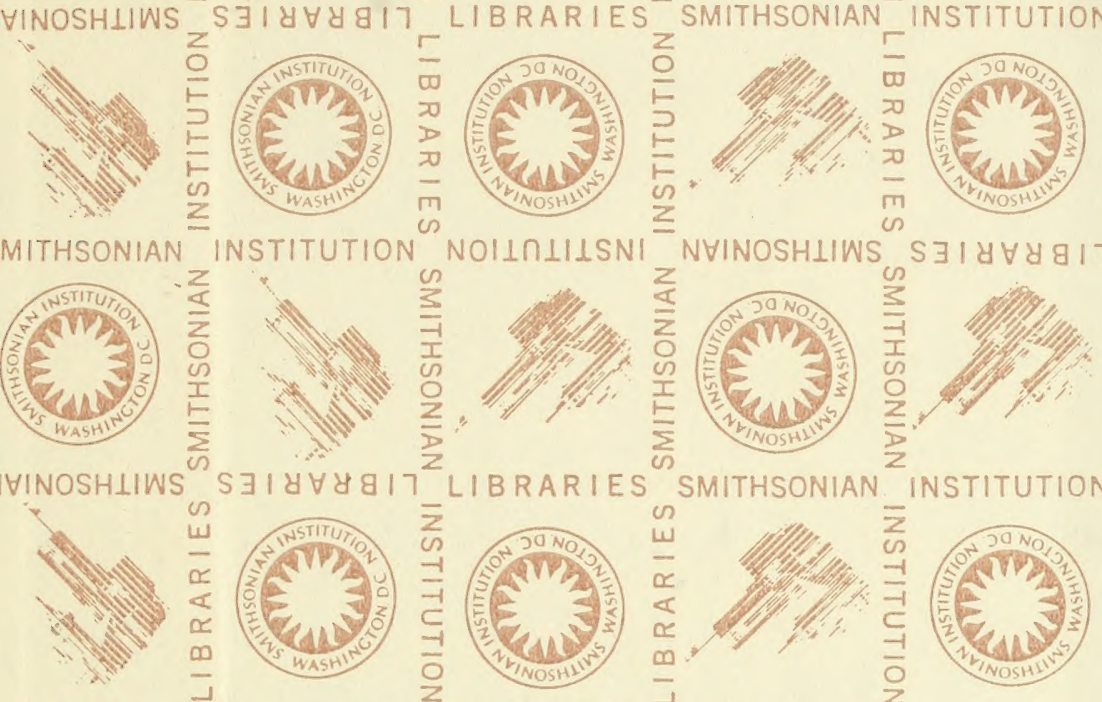

INSTITUTION

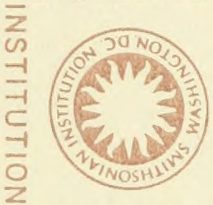

SMITHSONIAN
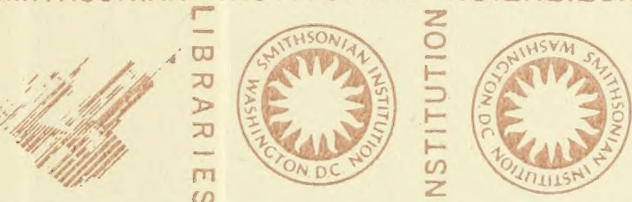

NVINOSHLIWS
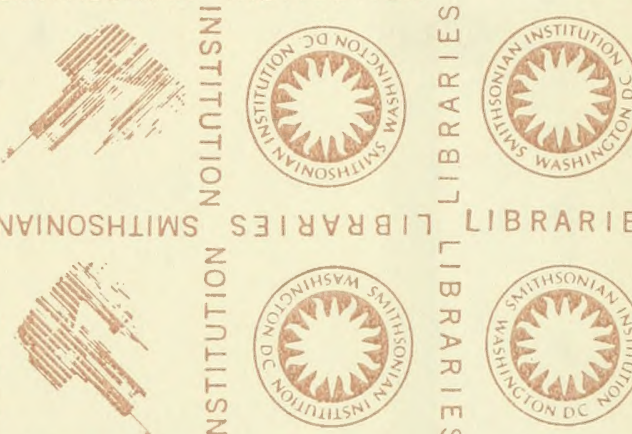

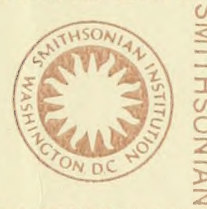

SMITHSONIAN
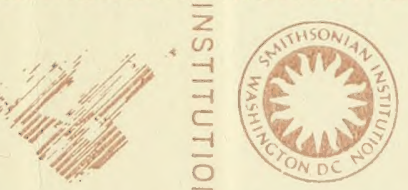

NVINOSHLIWS
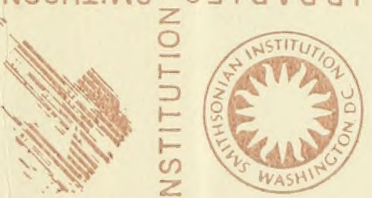
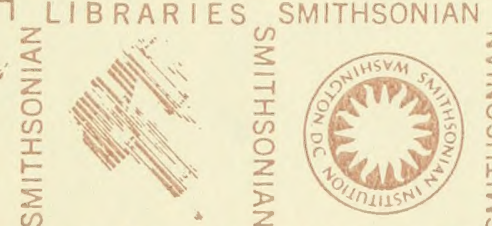
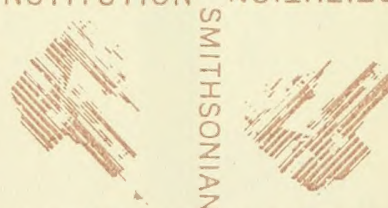

NHINOSHIIWS
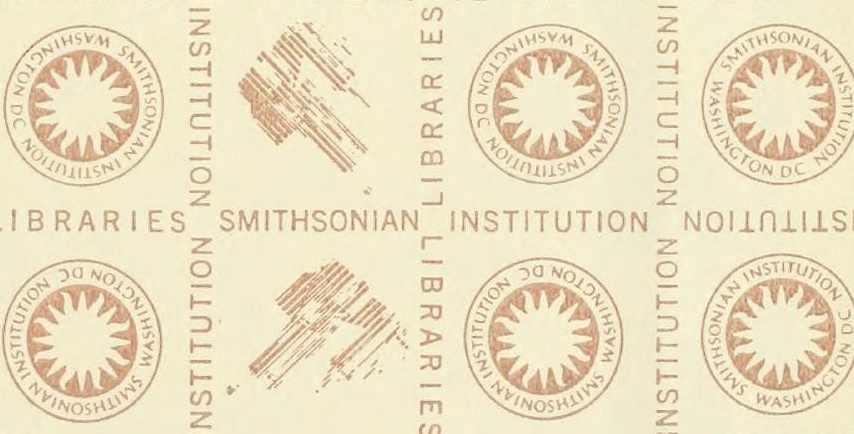

SMITHSONIAN
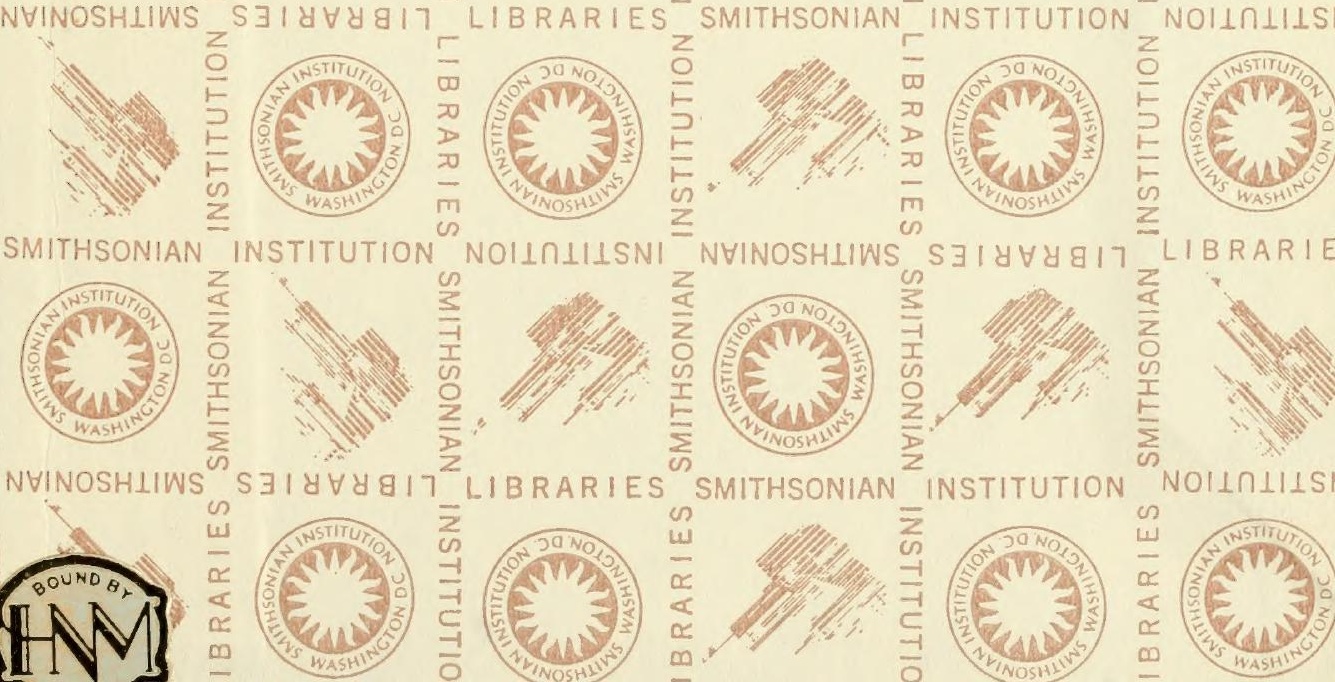


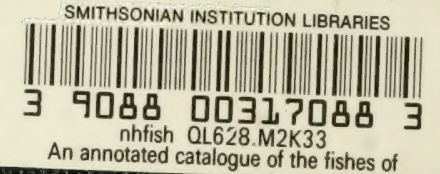

